UNIVERSIDADE DE SÃO PAULO

FACULDADE DE FILOSOFIA, LETRAS E CIÊNCIAS HUMANAS

DEPARTAMENTO DE LETRAS CLÁSSICAS E VERNÁCULAS

PROGRAMA DE PÓS-GRADUAÇÃO EM FILOLOGIA E LÍNGUA PORTUGUESA

ELISANGELA BAPTISTA DE GODOY SARTIN

GRAMATICALIZAÇÃO
DE COMBINAÇÃO DE ORAÇÕES:
ESTRUTURAS PARA + INFINITIVO NO PORTUGUÊS

V.1

São Paulo

2008 
UNIVERSIDADE DE SÃO PAULO

FACULDADE DE FILOSOFIA, LETRAS E CIÊNCIAS HUMANAS

DEPARTAMENTO DE LETRAS CLÁSSICAS E VERNÁCULAS

PROGRAMA DE PÓS-GRADUAÇÃO EM FILOLOGIA E LÍNGUA PORTUGUESA

\title{
GRAMATICALIZAÇÃO DE COMBINAÇÃO DE ORAÇÕES: \\ ESTRUTURAS PARA + INFINITIVO NO PORTUGUÊS
}

\author{
Elisangela Baptista de Godoy Sartin \\ lisaugusto@usp.br
}

Dissertação apresentada ao Programa de PósGraduação em Filologia e Língua Portuguesa do Departamento de Letras Clássicas e Vernáculas da Faculdade de Filosofia, Letras e Ciências Humanas da Universidade de São Paulo, para a obtenção do título de Mestre em Letras.

Orientadora: Profa. Dra. Maria Célia Lima-Hernandes

São Paulo

2008 
BANCA EXAMINADORA

$\overline{\text { Profa. Dra. Maria Célia Lima-Hernandes }}$ (orientadora)

USP

Profa. Dra. Nilza Barrozo Dias UFJF

Profa. Dra. Maria João Broa Martins Marçalo Universidade de Évora - Portugal

$\overline{\text { Prof. Dr. Manoel Mourivaldo Santiago Almeida }}$ (membro suplente)

USP

Profa. Dra. Vânia Cristina Casseb-Galvão (membro suplente)

UFG

Prof. Dr. Sebastião Carlos Gonçalves

(membro suplente)

UNESP - Rio Preto 
O trabalho é o esforço aplicado; é qualquer coisa a que nos dedicamos, qualquer coisa em que gastamos energia pa ra conquistar ou adquirir algo . O sentido fundamental do trabalho não é aquilo por que lutamos para viver, mas o que fazemos com nossa vida.

A felicidade, como Aristóteles disse há muito tempo, reside na atividade, tanto física como mental. Reside em fazer coisas de que se possa orgulhar por fazer bem e, portanto, que se tenha prazer em fazer.

(William J. Bennett) 
Dedico este trabalho a

José Augusto

Gustavo

Com os quais pude contar em todos os momentos! 
A Deus que me deu saúde, fé e muita força de vontade em vencer; por ter colocado em meu caminho uma pessoa tão iluminada para a missão de me orientar nessa difícil tarefa.

À minha orientadora Maria Célia Lima-Hernandes por acreditar no meu potencial e por ter contribuído para meu desenvolvimento no caminho da pesquisa científica; pela dedicação, companheirismo e principalmente em ser um exemplo para minha vida acadêmica.

À profa Nilza Barrozo Dias e ao prof. Heitor Megale pela leitura, comentários e sugestões apresentados no exame de qualificação.

À Lídia Spaziani, pelo carisma e pela grande ajuda nos muitos abstracts.

Ao meu marido, José Augusto, pela paciência e companheirismo constante, pois, embora não receba nenhum certificado, acabou fazendo parte do nosso grupo de pesquisa, estando em todos os momentos ao meu lado... sempre!

Ao meu filho Gustavo pela compreensão nos momentos de ausência.

Aos meus pais Olivio e Walkiria, que sempre fizeram questão que seus filhos estudassem.

Aos meus irmãos Elisabete, Eduardo, Emerson e Edson por serem pessoas que tenho a certeza de sempre poder contar.

Aos meus amigos Luciana, Ismael, Humberto, Neide, Gustavo, Simone, Verônica e Gabriel, pelos inúmeros momentos de alegrias que passamos juntos.

À minha cunhada Cristina pela ajuda na montagem dos gráficos. 
Aos meus amigos de curso Paulo, Kelly, Renata, Cristina, Elaine e Luciana por dividirem tanto os momentos legais de descontração quanto os momentos de preocupação.

Aos professores e alunos que colaboraram na aplicação e na participação dos testes deste trabalho.

A todos que contribuíram de forma direta ou indireta para que este trabalho pudesse ser realizado. 


\section{Resumo}

Esta dissertação de mestrado apresenta a análise do grau de coesão entre as orações combinadas na estrutura com a seguinte composição: a subordinada é não-finita e tem a preposição para encabeçando a oração. Numa abordagem sincrônica, pesquisamos o comportamento funcional dessa estrutura na modalidade falada e escrita por meio de critérios formais de controle com o fim de apreender a motivação de cada interpretação.

A estrutura para + infinitivo tem sido usada em outros contextos semânticos que não o de finalidade. Esses sentidos outros têm demonstrado um caráter mais abstratizado e, em alguns casos, um entrelaçamento sintático bastante acentuado com a oração-núcleo. Essa constatação fez com que fosse possível postular a instauração de um processo de intensa gramaticalização.

Tendo em vista que nem todas as orações configuradas neste tipo de padrão estrutural sinalizam finalidade no português do Brasil, procedo à identificação dos padrões funcionais, que denunciam a língua em sua dinamicidade gerando funções inovadoras a fim de atender às necessidades comunicativas dos falantes. Esta dissertação apresenta-se como uma contribuição da ciência lingüística ao trabalho pedagógico, em um diálogo bastante interessante por envolver a percepção do aluno, a decisão pedagógica do professor e a discussão teórica da lingüística contemporânea.

palavras-chave: orações combinadas; gramaticalização; entrelaçamento sintático; contextos semânticos; trabalho pedagógico. 


\begin{abstract}
This dissertation mastering work presents the analysis of the degree cohesion among combined sentences in their structure with the following composition: the subordinate is non-finite and it has the preposition para (to) heading it. In a synchronous approach, we search the functional behavior of this structure in the spoken and written modality by means of formal criteria of control in order to apprehend the motivation of each interpretation.

The structure to + infinitive has been used in other semantic contexts with several different meanings from the purpose meaning (the initial one). These other meanings have demonstrated a more abstraticized feature and, in some cases, a syntactic blending sufficiently accented with the main sentence. This confirmation has given the possibility of claiming the instauration of an intense grammaticalization process.

There is a view in which not all the sentences that are configured in this structural standard type sign to the purpose semantic feature in the Brazilian Portuguese. So I proceed to the identification of the functional standards that denounce the language in its dynamicity, it also generates innovative functions in order to embody the communicative needs of the speakers. This dissertation is presented as a contribution from the linguistic science to the pedagogical work, in a really interesting dialogue that involves the student perception, the pedagogical teacher decision and the linguistic contemporary theoretical discussion.
\end{abstract}

Keywords: combined sentences; grammaticalization; syntactic blending; semantic contexts; pedagogical work. 


\section{LISTA DE QUADROS}

Quadro 1 - Distribuição dos informantes .............................................................. 70

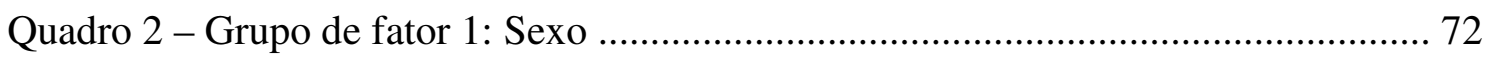

Quadro 3 - Grupo de fator 2: Estrutura formal ...................................................... 72

Quadro 4 - Grupo de fator 3: Material interveniente ................................................. 73

Quadro 5 - Grupo de fator 4: Valor semântico ......................................................... 74

Quadro 6 - Grupo de fator 5: Polaridade …….................................................... 75

Quadro 7 - Grupo de fator 6: Semântica do verbo ....................................................... 76

Quadro 8 - Grupo de fator 7: Presença do sujeito ...................................................... 77

Quadro 9 - Amostra de Redações Vestibulares - FUVEST ...................................... 101

Quadro 10 - Grupo de fator 1: Estrutura formal ....................................................... 102

Quadro 11- Grupo de fator 2: Material interveniente .............................................. 102

Quadro 12 - Grupo de fator 3: Valor semântico ...................................................... 103

Quadro 13 - Grupo de fator 4: Polaridade ............................................................ 105

Quadro 14 - Grupo de fator 5: Semântica do verbo ................................................... 106

Quadro 15 - Grupo de fator 6: Presença do sujeito ................................................... 107

Quadro 16 - Distribuição de informantes nas escolas básicas ................................... 122

Quadro 17 - Alunos da 8 a série - Escola Particular ................................................ 123

Quadro 18 - Alunos do ensino médio - Escola Particular ........................................ 125

Quadro 19 - Alunos da 8 a série - Escola Pública ...................................................... 126

Quadro 20 - Alunos do ensino médio - Escola Particular ........................................ 128

Quadro 21 - Alunos do ensino médio - Meninos .................................................... 129

Quadro 22 - Alunos do ensino médio - Meninas .................................................. 130

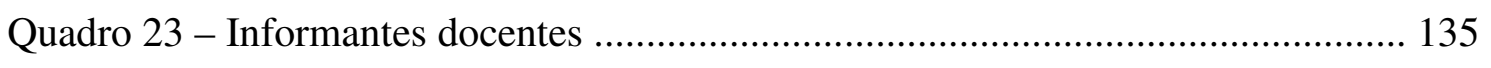

Quadro 24 - Resultados de associações docentes ................................................... 136 


\section{LISTA DE TABELAS}

Tabela 1 - Correlação sexo do informante X valor semântico ..................................... 79

Tabela 2 - Correlação estrutura forma X valor semântico .......................................... 80

Tabela 3 - Correlação material interveniente X valor semântico ................................. 82

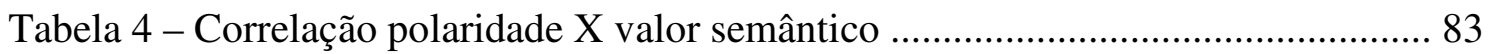

Tabela 5 - Correlação verbo complemento da preposição X valor semântico ............... 85

Tabela 6 - Correlação característica do sujeito X valor semântico ............................... 90

Tabela 7 - Correlação estrutura formal X valor semântico ........................................ 109

Tabela 8 - Correlação material interveniente X valor semântico ............................... 110

Tabela 9 - Correlação polaridade X valor semântico ................................................. 111

Tabela 10 - Correlação verbo complemento da preposição X valor semântico ........... 113

Tabela 11 - Correlação sujeito sintático X valor semântico ...................................... 116

\section{LISTA DE GRÁFICOS}

Gráfico 1- Teste de conexão - Alunos do ensino fundamental ................................ 124

Gráfico 2- Teste de conexão - Alunos do ensino médio ........................................... 126

Gráfico 3 - Teste de conexão - Alunos do ensino fundamental ............................... 127

Gráfico 4 - Teste de conexão - Alunos do ensino médio ......................................... 128

Gráfico 5 - Teste de conexão - Meninos do ensino médio ....................................... 129

Gráfico 6 - Teste de conexão - Meninas do ensino médio .......................................... 131 
RESUMO

08

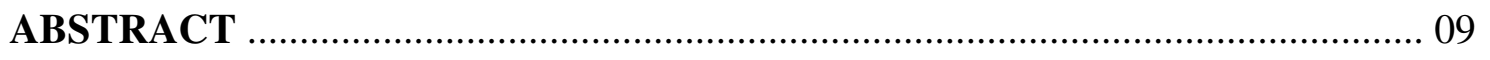

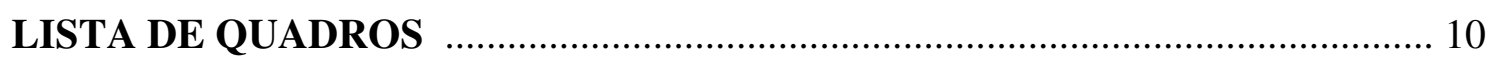

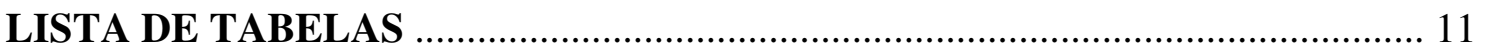

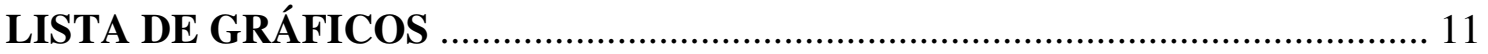

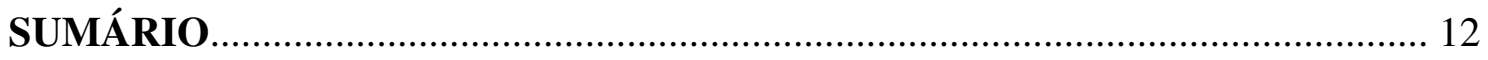

INTRODUÇÃ

CAPÍTULO I

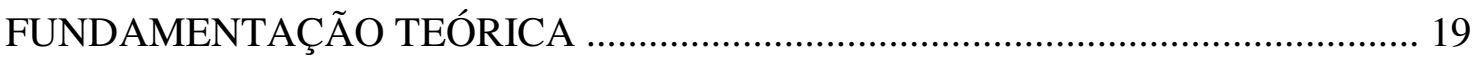

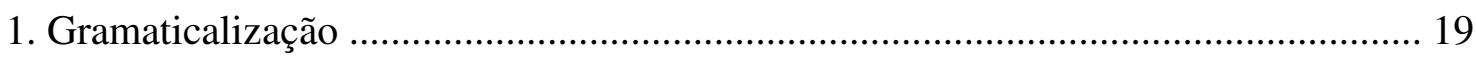

2. Gramaticalização de combinação de orações ........................................................ 23

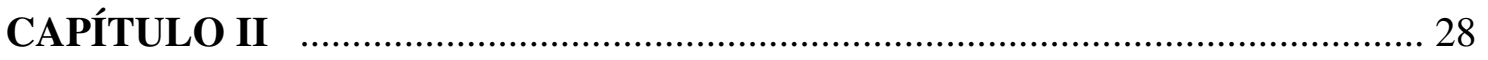

ESTRUTURA PARA+INFINITIVO NO PORTUGUÊS:

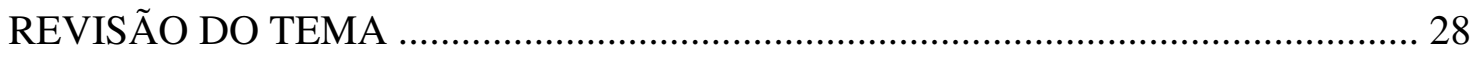

1. Raízes da estrutura para+infinitivo nas gramáticas: Revisão Histórica .................... 28

2. Estrutura para+infinitivo nas gramáticas: Normatização ........................................... 33

2.1. Um ponto de partida funcionalista: A gramática de usos ................................. 34

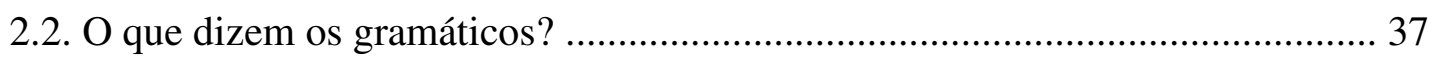

2.3. Como a escola tem lidado com essa questão? ................................................. 40

3. Estrutura para+infinitivo: Pesquisas lingüísticas ................................................... 44 
AMOSTRA DE LÍNGUA FALADA - ANÁLISE DOS DADOS

1. Língua falada: Constituição do corpus ........................................................................ 69

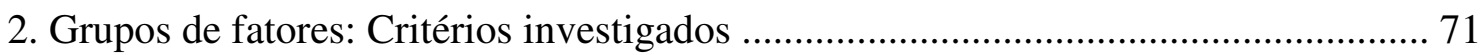

3. Produtividade na língua falada: Padrões funcionais ................................................ 79

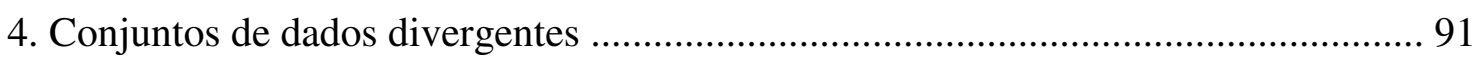

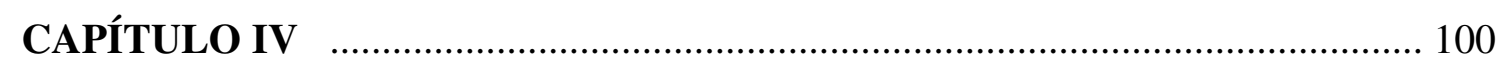

TRANSMISSÃO E INCORPORAÇÃO DA NORMATIVIDADE

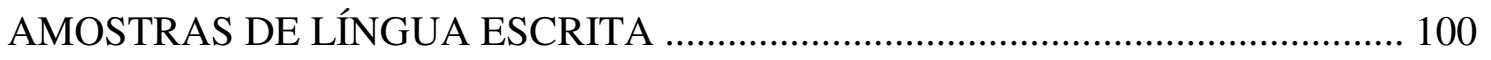

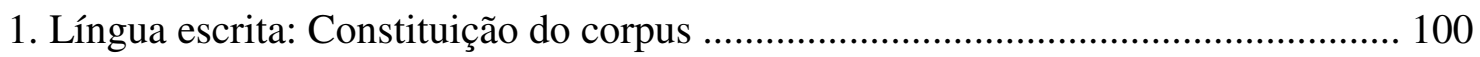

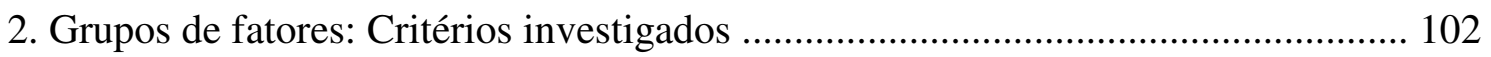

3. Produtividade na língua escrita: Padrões funcionais ............................................. 109

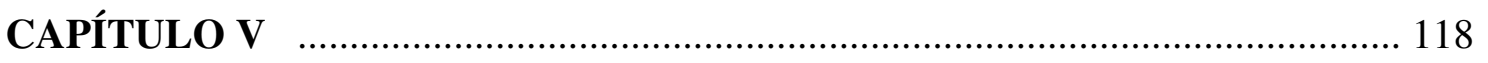

TRANSMISSÃO E INCORPORAÇÃO DA NORMATIVIDADE

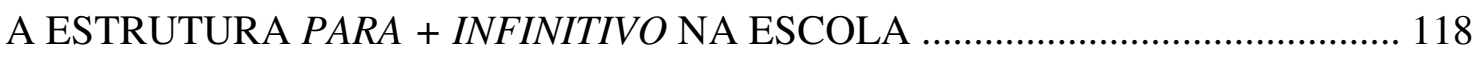

1. O uso preferencial dos conectores em orações finais: A aplicação do teste ............. 118

2. O uso preferencial dos conectores em orações finais: Os resultados ...................... 123

3. Os educadores estão atentos para as mudanças das estruturas para + infinitivo? .. 133 


\section{INTRODUÇÃO}

Este texto tem por objetivo apresentar o percurso do meu trabalho de pesquisa desde que ingressei no curso de Mestrado, quando apresentei um projeto de investigação sobre os deslizamentos funcionais que as orações encabeçadas por para + infinitivo apresentam.

É um tema que merece bastante destaque e atenção por parte dos pesquisadores, pois, a despeito de manter a mesma configuração, a estrutura tem seu sentido original erodido e, em alguns casos, esse sentido mostra-se enfraquecido, gerando uma ambigüidade interpretativa.

A estrutura para + infinitivo tem sido empregada para dar conta de outros contextos semânticos que não o de finalidade, e esses sentidos outros têm demonstrado um caráter mais abstratizado; em alguns casos, um entrelaçamento sintático bastante acentuado com a oração-núcleo, o que denunciaria uma mudança de estatuto gramatical. Essa constatação fez com que eu postulasse a instauração de um processo de intensa gramaticalização. Esse é o motivo de iniciar este texto apresentando as bases fundamentais da gramaticalização.

Tendo em vista que a gramaticalização, em sua explanação num modelo mais tradicional, envolve itens lexicais, uma transposição desse conceito foi feita para o estudo e explanação da combinação de orações. Esse encaminhamento, contudo, não é proposta exclusiva deste trabalho. Outros lingüistas (LIMA-HERNANDES, 1998; DIAS, 2001; HOPPER \& TRAUGOTT, 1994, dentre outros) procederam a pesquisas 
nessa perspectiva, com resultados significativos para a compreensão dos deslizamentos funcionais.

No capítulo 1, apresento os estudos sobre gramaticalização, pois, embora esse processo de mudança tenha sua definição primitiva relacionada a palavras individuais, apresento também autores que lidam com mudanças não só atinentes a itens lexicais, mas também a unidades maiores; neste estudo, tratarei do período composto.

Para isto, selecionei Meillet (1912), Heine, Claudi e Hünnemeyer (1991:2), Bybee, Perkins e Pagliuca (1994), Lyle Campbell e Richard Janda (2000), que expõem a definição de gramaticalização como um processo que consiste em mudança de um item lexical para um gramatical, ou de um item menos gramatical para um mais gramatical. Nem sempre, contudo, a gramaticalização tem sido uma definição tranqüila entre os estudiosos das línguas, e alguns desses estudiosos colocam em discussão todo o estatuto teórico da gramaticalização.

Ainda no capítulo 1, autores como Heine, Claudi e Hünnemeyer (1991), Heine (1993), Hopper \& Traugott (1991, 1993 e 1994) lidam com a gramaticalização não só no nível lexical, mas também no nível de unidades maiores, como é o caso das orações complexas. Hopper \& Traugott (1993), mais especificamente, traçam um continuum da combinação de orações, por meio do que, sob o ponto de vista da gramaticalização, é possível uma aplicação às orações adverbiais, quando estas passam de uma menor integração para uma maior integração.

No capítulo 2, apresento a resenha crítica dos trabalhos publicados sobre o tema, iniciando por uma revisão histórica, para que, dessa forma, seja possível verificar se essas mudanças já eram percebidas por autores de épocas distintas Para essa tarefa, 
consultei Mattos e Silva (1989), Said Ali (1971), Epiphânio Dias (1970), Maurer Jr. (1962) e Coutinho (1974).

Em seguida, elaborei um resumo sobre a temática da estrutura para + infinitivo à luz das idéias veiculas em alguns gramáticos (LUFT, 1978; CUNHA \& CINTRA, 1985; BECHARA, 1999) com o fim de verificar a normatização corrente, a partir do que poderei checar a existência ou ausência de informações sobre os usos "inovadores".

Numa etapa seguinte, então, elaborei uma lista de livros didáticos de grande circulação em escolas e os consultei sobre esse respeito. Os livros selecionados foram Cipro Neto \& Infante (1997), Cereja e Magalhães (2004), Maia (2003) e Terra e Nicola (2004), também estabelecendo um cotejo com uma descrição sincrônica feita por Moura Neves (2000).

A partir dessas incursões, será possível observar se o processo de deslizamentos funcionais, ambigüidades interpretativas e divergências semânticas estariam presentes em livros didáticos. A intenção é lidar com as interpretações geradas e repetidas no processo de escolarização, haja vista que, na condição de professora de escola pública, tenho notado um descompasso entre o que postulam os gramáticos e o que a escola tem veiculado e passado como modelo entre os jovens.

Ainda no mesmo capítulo, apresento a pesquisa sobre descrições numa perspectiva lingüística, consultando Ferrari (1998), Braga (1999), Gorski (2000, 2001, 2003 e 2004), Dias (2002, 2005), Azevedo (2002), Salles (2003), Lima (2004), Menezes (2004), Silva (2005) e Lima-Hernandes (1998, 2004). Com base na análise desses pesquisadores, numa orientação funcionalista, procedi ao levantamento e análise das ocorrências. Por meio dessa incursão, espero depreender as propriedades e 
características peculiares que permitiriam uma organização em padrões funcionais da estrutura sob análise para poder verificar a diversidade semântica da estrutura sob análise.

No capítulo 3, apresento o estudo da movimentação da estrutura para + infinitivo na língua falada, pois é fato que a fala demonstra-se mais rica em usos. Assim, para esta tarefa, o corpus analisado foi composto a partir de amostras do português culto de São Paulo (NURC-SP - Projeto Norma Urbana Culta). A metodologia adotada para o tratamento dos dados deriva da Sociolingüística laboviana. Essa orientação metodológica providencia o contato com o pacote de programas informáticos Varbrul Variable Rules, em parte do trabalho, entretanto aplicado fora do arcabouço variacionista.

Nesse mesmo capítulo, apresento um conjunto de dados tão divergentes nos usos da língua, que é quase impossível sua classificação tanto sintática quanto semântica segundo os moldes tradicionais. No entanto, o objetivo é apresentar a dificuldade em analisar e classificar dados como os identificados, o que nos leva a compreender o porquê de tanta dificuldade em ensinar e aprender gramática normativa nas escolas.

No capítulo 4, apresento a movimentação da estrutura focalizada, agora voltando-me para a língua escrita. Para essa tarefa, foram selecionadas redações de vestibular da FUVEST, referentes aos anos de 1999, 2001, 2002 e 2006. Essa estratégia me permitirá realizar um estudo sobre a incorporação de usos inovadores e sobre o peso da normatividade oriunda do ensino formal colegial. Também lançamos mão da metodologia adotada para o tratamento dos dados na Sociolingüística laboviana, com o uso de alguns dos programas informáticos do Pacote Varbrul - Variable Rules, naturalmente fora do arcabouço variacionista. 
No capítulo 5, há o relato da estratégia adotada na pesquisa para que eu pudesse explicar como se dariam a transmissão e a incorporação da normatividade de estruturas para + infinitivo na escola. Para essa tarefa, procedo à aplicação de um teste sobre o uso preferencial dos conectores em orações finais. São informantes nesse teste alunos da $8^{\mathrm{a}}$ série do Ensino fundamental e alunos do $3^{\circ}$ ano do Ensino Médio, com o objetivo de reconhecer se de fato a opção de conectores de uma geração mais nova é a mesma do que é proposto nos livros didáticos. Ainda nesse capítulo, apresento a estratégia e os respectivos resultados da aplicação de um teste para professores de Língua Portuguesa. O objetivo era promover um teste de percepção da mudança lingüística com um grupo de pessoas que fazem da normatividade sua ferramenta de trabalho, o que lhes pode tornar cegar a inovações ou usos emergentes.

Em suma, esta dissertação é um grande relato dos passos adotados numa pesquisa de mestrado cuja contribuição pode ser circunscrita a uma linha de pesquisa lingüística sobre mudança gramatical (gramaticalização), mas que em suas estratégias metodológicas ganha relevância num diálogo importante entre pesquisa e escola, dado que oferece subsídios ao trabalho pedagógico na área de Gramática.

O produto desta pesquisa apresenta-se academicamente vinculado ao Grupo de Pesquisa CNPq/USP "Mudança Gramatical do Português" e ao Projeto Temático "História do Português Paulista" (FAPESP/USP), coordenado pelo Prof. Ataliba T. de Castilho (USP). 


\section{CAPÍTULO I}

\section{FUNDAMENTAÇÃO TEÓRICA}

Este capítulo constitui-se como a base fundamental desta dissertação. Nele, apresento os postulados e asseverações derivadas dos estudos sobre gramaticalização, depois, aplicados à combinação de orações. $\mathrm{O}$ modo como recupero os conceitos sobre gramaticalização e os aplico a unidades maiores - o período composto - permite discutir a complexidade do termo "gramaticalização", que deixa de se aplicar a um item lexical e passa a tomar como alvo de incidência as orações e suas relações.

\section{Gramaticalização}

Nesta seção, apresento a definição de gramaticalização além dos princípios que regem esse processo. Essas definições serão importantes para a análise que apresento posteriormente com relação às estruturas para + infinitivo, por auxiliarem na compreensão dos mecanismos que atuam nos deslizamentos funcionais identificados.

Heine, Claudi e Hünnemeyer (1991:2) expõem o seguinte conceito sobre gramaticalização:

Where a lexical unit or structure assumes a grammatical function, or where a grammatical function, we are dealing with grammaticalization, a process that can be found in all languages know to us and may involve any kind of grammatical function. 
Para esses autores, gramaticalização é um processo que pode ocorrer em todas as línguas e que pode envolver um tipo de função gramatical. Na análise sincrônica, a gramaticalização fornece uma mudança para noções de classes de morfemas discretos ou constituintes oracionais, e consiste em mudança de um item lexical para um gramatical, ou de um item menos gramatical para um mais gramatical.

Segundo os autores, esse movimento no sistema, do modo como foi apresentado, vincula-se mais estreitamente com a morfologia e morfossintaxe da língua ${ }^{1}$. Essa abordagem, contudo, não dá conta dos movimentos intermediários ocorridos na passagem de um item lexical para um gramatical, razão pela qual é preciso construir hipóteses específicas sobre a ordem sintática e a estrutura da língua num estágio anterior a esse desenvolvimento histórico.

Mais recentemente, o aspecto discurso-pragmático vem sendo reconhecido como uma instância importante para a compreensão da estrutura da língua em geral e do desenvolvimento de estruturas sintáticas e categorias gramaticais em particular.

Devemos nos lembrar de que já em Meillet (1912) encontra-se uma definição para o termo grammaticalisation como um fenômeno dinâmico: "le passage d'un mot autonome au role d'elément gramatical". Deste modo, as palavras passariam de categorias lexicais plenas a categorias gramaticais. Não havia, naquele contexto de pesquisa, ainda, o tratamento dos vários níveis da lingüística em suas correlações, como tentamos fazer hoje, mas foi um momento importante dos desenvolvimentos da ciência para que chegássemos a elaborar os questionamentos no formato atual.

\footnotetext{
${ }^{1}$ Esses autores relacionam essa forma de abordagem ao trabalho feito por Givón.

${ }^{2}$ Apud Hopper \&Traugott (1994).
} 
Nesse formato mais recente de pesquisa sobre gramaticalização, está o trabalho de Bybee, Perkins e Pagliuca (1994), que propõem mecanismos motivadores da gramaticalização com base em mecanismos de transformação, quais sejam: extensão metafórica, inferência, generalização, harmonia e absorção.

O mecanismo de transformação gramatical denominado extensão metafórica caracteriza-se por meio da mudança de um domínio mais concreto para um domínio mais abstrato e pela preservação de algum traço da estrutura relacional original. A inferência remete diretamente à implicatura, pois enquanto o falante obedece ao princípio da informatividade e da economia, o ouvinte extrai todos os significados necessários à compreensão da asserção. A generalização representa a perda de traços específicos de significado, com a conseqüente expansão de contextos apropriados para o uso. Para esse mecanismo, a freqüência de uso mostra-se bastante relevante. O processo de mudança caracterizado por harmonia diz respeito ao mecanismo restrito aos elementos gramaticais que se encontram desprovidos de maior parte de seu conteúdo semântico. Por fim, a absorção compreende a completa gramaticalização do item observado, é o momento da criação de um gram zero.

Aplicando esses conceitos ao fenômeno priorizado nesta dissertação, pode-se prever que uma estrutura para + infinitivo poderia passar pelas transformações sugeridas por Bybee, Perkins e Pagliuca. Assim, uma estrutura tipicamente sinalizadora de finalidade poderia passar por um processo de mudança metafórica que desencadearia, sob o ponto de vista da recepção, ou seja, sob o ponto de vista da percepção dos interlocutores, uma inferência ambígua. O passo seguinte seria ilustrado pela ampliação do valor de finalidade para outros tipos de estruturas sintáticas, tais como se observa na generalização de função, harmonizando por analogia todas as demais estruturas e 
alcançando seu estágio máximo de mudança por gramaticalização com a absorção daquela seqüência inovadora. Deste modo, a partir de uma estrutura tipicamente de finalidade, poderíamos falar de uma ampliação desse valor para outras estruturas sintáticas com para + infinitivo.

Nem sempre, contudo, a gramaticalização tem sido uma definição tranqüila entre os estudiosos das línguas. Lyle Campbell e Richard Janda (2000), por exemplo, colocam em questão a opinião de vários outros autores, inclusive com relação ao estatuto teórico da gramaticalização. Restrinjo esta exposição aos argumentos de Campbell e Janda, por representarem uma forte oposição ao arcabouço teórico que aqui assumimos.

Para os autores, a mudança lingüística efetiva-se independentemente da instauração de um processo de gramaticalização. Consideram que muito do que se atribui à gramaticalização provém de explicações que fogem à alçada desse processo:

I attempt to show that grammaticalization is derivative, that is, that grammaticalization has not true status of its own, but rather relies on other processes and mechanisms of linguistic change which exist independently of grammaticalization but which provide the explanations for the phenomena involved in grammaticalization. (p. 113)

O ponto criticado diz respeito à abrangência da gramaticalização. Baseados em Heine (1993), que investiga a auxiliarização verbal, os autores afirmam que gramaticalização não envolve o estudo somente de significados de fatos presentes na língua, ocorridos no passado, mas que também permite a previsão de desenvolvimentos futuros. Creio, contudo, que isso não afete a abrangência do processo de 
gramaticalização, pois prevê-se a atuação do princípio do uniformitarismo (Labov, 1972). Explico: se a mudança da estrutura para + infinitivo está ocorrendo no presente, certamente já há evidências desse movimento no passado e, por meio de uma descrição criteriosa, podem-se prever movimentos futuros.

Com relação ao tipo de unidade que o processo de gramaticalização pode tomar por escopo, se no passado isolava-se somente o item lexical para estudo da gramaticalização, hoje se nota uma ampliação ou complexificação do tipo de unidade. Essa é lógica dos avanços lingüísticos em todo ramo científico: amplia-se o alvo das investigações em face dos resultados já alcançados com alvos mais restritos. Se, em sua aplicação mais antiga, o rótulo tomava como alvo um item lexical, posteriormente houve o exercício de aplicação a unidades maiores, tal como explano a seguir.

\section{Gramaticalização de combinação de orações}

O processo de gramaticalização pode ser aplicado a estruturas maiores, como demonstrou Braga (1999), dentre outros autores. Uma estrutura sintática maior pode ser compreendida como um componente discursivo, mas pode também ser derivado de estrutura discursiva (SANKOFF e BROWN, 1976, apud HEINE, CLAUDI e HÜNNEMEYER, 1991).

Também Givón, resenhado por Heine, Claudi e Hünemmeyer (1991), demonstrou que o processo de gramaticalização pode abranger um modelo mais pragmático de comunicação, enfatizando, dessa forma, o aspecto sintático. De acordo com essa perspectiva, estruturas paratáticas do discurso podem desenvolver-se em estruturas sintáticas mais fechadas, como o encaixamento. 
Essa linha de pesquisa tem aberto uma nova janela nos estudos de gramaticalização. Nesse sentido, passa a tratar de gramaticalização não como simples "reanálise do item lexical como material gramatical”, mas também como a reanálise do padrão discursivo como padrão gramatical e de funções do nível discursivo, tais como nível de sentença, funções semânticas ${ }^{3}$.

Hopper \& Traugott (1994) afirmam que, durante o período neogramático, todas as investigações de morfologia gramatical tiveram o caráter essencialmente de investigações sobre a analogia, tal como fazia Meillet. Era o que se previa nos encaminhamentos metodológicos da época; não se poderia esperar que adotassem abordagens diversas àquelas compatíveis com o estágio de avanços lingüísticos na época da produção.

Lembremo-nos de que muito do interesse científico na área lingüística era voltado para a gramática histórico-comparativa. Então, muito do que explicava a mudança paradigmática relacionava-se com a analogia, e a gramaticalização parece assumir um caráter mais sistemático e, ao mesmo tempo, mais amplo:

A importância [disto] é um fato decisivo. Enquanto a analogia pode renovar formas em detalhe, geralmente deixando o plano total do sistema intocável, a gramaticalização de certas palavras cria novas formas e introduz categorias que não têm expressão lingüística. Muda o sistema como um todo. (apud HOPPER \& TRAUGOTT, 1994:22).

Gramaticalização, ainda que tenha sua definição primitiva relacionada a palavras individuais, evidentemente é um conceito que também pode ser estendido para itens maiores. Na verdade, a combinação de palavras em frases e sua eventual amalgamação,

\footnotetext{
${ }^{3}$ São citados como autores que lidam com essa abordagem os seguintes: Hopper 1979a; 1979b; 1982, Herring 1988; Thompson e Mulac, in press (apud HEINE, CLAUDI e HÜNNEMEYER,1991).
} 
como demonstrado por Lima-Hernandes \& Sartin (2006) com os verbos volitivos, é motivada por fatores discursivo-pragmáticos, e a codificação sintática preserva as estruturas antigas numa nova função ${ }^{4}$. Em um caso extremo, a frase pode mesmo ser analisada como contendo mais que uma palavra, mas seus membros são integrados como um. Em assim sendo, já em Meillet, há a possibilidade de que o domínio da gramaticalização possa ser estendido para a ordem das palavras nas sentenças.

Durante a década de 70, ocorreu um crescimento no interesse da pragmática e da tipologia lingüística. Nesse momento, muitos lingüistas focaram a atenção nas mudanças previsíveis nos tipos de línguas. Givón começa essa retomada, intitulando "Sintaxe Histórica e morfologia sincrônica; uma viagem à área da arqueologia", e anuncia o slogan "A morfologia de hoje é a sintaxe de ontem". Sobre as formas discursivas, Givón propõe que sejam localizadas num continuum e que se movimentem entres dois pólos: pragmático > sintático.

É certo que, em se tratando de combinações de orações, nota-se, tal como defendem Hopper e Traugott, que há diferenças claras entre orações combinadas em sua forma finita e orações combinadas em sua forma não-finita. Se um núcleo canônico contém um verbo finito, pode ocorrer decategorização nos casos em que envolver redução do verbo na forma não-finita.

Um caso especial de integração é o que Lehmann chama "interlacing", : a concordância sintática entre as orações, por exemplo, demonstra esse tipo de integração. Outros critérios têm sido aventados como índices de integração de orações. São eles: correferencialidade de sujeitos, identidade de tempos e modos e também o

\footnotetext{
${ }^{4}$ Lima-Hernandes \& Sartin (2006) discutem os casos de estruturas volitivas que geram o efeito discursivo de imperatividade, como em Eu quero que você leia este texto.

${ }^{5}$ Apud Hopper \& Traugott (1994)
} 
entrelaçamento de orações originalmente separadas na estrutura sintática da matriz. É o caso da ocorrência de um sujeito oracional, quando uma oração matriz assume como sujeito a oração seguinte.

Hopper e Traugott (1993) traçam um continuum (cline) da combinação de orações do ponto de vista da gramaticalização, tal como explicitado em:
Parataxe
hipotaxe
subordinação
(independência)
(interdependência)
(dependência)

A parataxe é caracterizada pela independência entre as orações que compõem a sequiência; hipotaxe, evidenciada pela interdependência entre as orações combinadas e pela presença de orações-satélite; e subordinação ${ }^{6}$, marcada pelo grau máximo de dependência, com uma das orações funcionando como constituinte da outra.

As orações adverbiais mostram um continuum de uma menor integração para uma maior integração, o que caracteriza um processo de gramaticalização em orações com maior grau de entrelaçamento. Esse grau dependerá, naturalmente, do valor semântico codificado e da codificação sintática.

Desta forma, é possível associar o processo de gramaticalização ao nexo sintático que se estabelece entre duas ou mais orações subordinadas (HOPPER \& TRAUGOTT, 1991). Nessa concepção de gramaticalização, quanto maior o grau de coesão, maior será seu grau de gramaticalização. Isso se deve ao entrelaçamento cada vez mais intenso entre unidades, o que faz com que um falante interprete a estrutura

\footnotetext{
${ }^{6}$ Para evitar a confusão entre hipotaxe e subordinação, muito comum na visão gramatical tradicional, doravante tratarei de subordinação como Encaixamento.
} 
toda não como duas unidades, mas como apenas uma. $\mathrm{O}$ que invariavelmente se tem mostrado é que o verbo da oração matriz ${ }^{7}$ (numa aplicação às orações encaixadas) sofre decategorização, podendo inclusive gerar uma leitura de auxiliaridade.

Uma questão que se impõe é se os critérios empregados para verificar a integração de orações podem ser aplicados à análise de um tipo muito particular de orações hipotáticas: as orações reduzidas de infinitivo introduzidas por para. Para obter essa resposta, será necessário retomar, no capítulo em analiso os dados, a idéia de interlacing e também de continuum tratados, respectivamente, por Lehmann e por Hopper \& Traugott.

\footnotetext{
${ }^{7}$ As orações que se combinam com orações encaixadas são rotuladas, nesse modelo, de orações-matriz, embora também utilize o rótulo "oração principal". Essa denominação não se aplica às hipotáticas, que se combinam necessariamente com orações-núcleo.
} 


\title{
CAPÍTULO II
}

\section{ESTRUTURA PARA+ INFINITIVO NO PORTUGUÊS REVISÃO DO TEMA}

\begin{abstract}
Sob uma abordagem sincrônica da gramaticalização, focalizarei, nesta dissertação, as estruturas complexas, introduzidas pela preposição para + infinitivo, que, de antemão (e equivocadamente), pode sugerir ao interlocutor seu valor funcional de finalidade. Mostrarei que nem sempre esse tipo de oração codifica de fato a finalidade da oração-núcleo. Para tanto, neste capítulo, inicio com uma revisão histórica do tema, apresento uma leitura dos trabalhos desenvolvidos sobre orações para + infinitivo e a análise que os autores dessas pesquisas ou gramáticas constroem sobre esse uso no português do Brasil.
\end{abstract}

\section{Raízes da estrutura para + infinitivo: Revisão histórica nas gramáticas}

Nessa seção, inicio a apresentação com uma revisão histórica do tema, e para isto, selecionei Mattos e Silva (1989), Said Ali (1971), Epiphânio Dias (1970), Maurer Jr.(1962) e Coutinho (1974), para que na seção seguinte, possa elaborar um estudo comparativo gramatical, com base em gramáticos do século $\mathrm{XX}$.

Em conformidade com os pressupostos teóricos apresentados na fundamentação teórica sobre gramaticalização em que Meillet (1912) assume um importante lugar na fase dos estudos de gramaticalização que assumiam uma abordagem diacrônica (embora nem todos os autores dessa época compusessem um corpus diacrônico nos moldes de hoje). 
No final do século XX (aproximadamente em fins da década de 80), a grande novidade desses estudos foi a abordagem sincrônica como forma de reconhecer a deflagração do processo de gramaticalização.

Atualmente, temos em alguns estudos sobre gramaticalização como primeira tarefa a discussão histórica do tema com o fim de compor um retrato de várias sincronias analíticas. Este trabalho revela-se, assim, uma contribuição científica por apresentar uma cuidadosa análise sincrônica que subsidiará em grande medida o estudo do fenômeno numa abordagem pedagógica (discutindo gramáticas, propondo testes, dentre outras estratégias adotadas).

Para iniciarmos essa seção, parto da explanação da idéia que fazem os gramáticos históricos sobre as estruturas para+infinitivo, e como esta tem sido trabalhada ao longo dos anos.

Mattos e Silva (1989) seleciona como corpus de sua pesquisa a documentação arcaica que se estende por três séculos a fim de observar os reflexos das mudanças lingüísticas que ocorreram na língua nesse período histórico.

É na seção sobre orações subordinadas que a autora cita a estrutura alvo desta pesquisa. Mattos e Silva avalia que as estruturas pera + infinitivo são mais recorrentes do que a variante sintática que + finita, semanticamente correspondente a "para que + verbo finito". Essas estruturas sintáticas, já no português arcaico, codificavam exclusivamente a finalidade.

Said Ali (1964) e Epiphânio Dias $(1970)^{8}$, que descrevem com certo grau de espanto o aparecimento da preposição em textos arcaicos, atribuem tal uso à ausência de

\footnotetext{
${ }^{8}$ De acordo com o autor, no próprio latim pré-romântico o emprego do dativo ou de $a d$ é às vezes indiferente (pág. 108)
} 
“esforço normativo". Para os autores, a inclusão da preposição pera nesse tipo de estrutura é desnecessária, posto que não desempenha nenhuma função na sentença. Explicam que a motivação para esse emprego deriva de "cruzamento sintático". Como esse argumento não é adequadamente explanado nas referências citadas, suspeito que a leitura que faziam era que essa estrutura resultara da mescla de duas outras estruturas. Se isso for um fato, depreende-se que o uso de preposição nesses casos seria uma inovação.

Ressalto que o termo inovação deve ser excluído de uma leitura mais normativa, equivalente a erro. Essa subversão da acepção que adoto não é novidade. Já em Maurer Jr. (1962), que descreveu o latim vulgar, notamos a presença de estruturas que não se encaixavam em concepções normativistas.

Said Ali, durante todo o seu trabalho, preocupa-se em identificar a variação de categorias gramaticais em virtude da mudança de sentido. Lida basicamente com o português histórico em dois períodos: o antigo (até os primeiros anos do século XVI) e o moderno (1520-culminando, em 1572, com a obra Os Lusíadas).

As formas não-finitas verbais, segundo esse autor, já no latim sofriam alterações. Assim é que o gerúndio-acusativo regido de $a d$, e o gerúndio-dativo, que já em latim vinha sendo suplantado pelo uso do acusativo com $a d$, foram substituídos por infinitivo precedido de, a ou para. Se minha interpretação estiver correta, posso afirmar que o infinitivo foi ganhando em expansão de uso frente às formas gerundivas.

As formas infinitivas (flexionadas ou não) podem, na evolução do português, aparecer acompanhadas das preposições até, para, com, em, sem, por, em vez de, antes de, depois de, além de, sobre, entretanto a forma não-flexionada (impessoal) emprega- 
se, segundo Said Ali, somente quando houver referência a ação, tal como no exemplo: "Armemo-nos de prudencia e paciencia pera receber os contrastes desta vida"9 (Arrais,81, apud SAID ALI, 1971).

Afirma, ainda, que, estando o agente do verbo em evidência, emprega-se o infinitivo pessoal. Assim, a presença de um complemento e a necessidade de pôr em evidência um sujeito novo podem determinar o emprego da forma pessoal na construção para + infinitivo : "ele as [letras] pos alli escudo era pera a verê e elle pera se guardare dele" ( Francisco de Morais, Palm.1,361, apud SAID ALI, 1971).

Essa observação feita pelos gramáticos históricos sobre a motivação para o emprego da estrutura para + infinitivo ser a necessidade de argumentos e de pôr em evidência um sujeito novo será retomada mais adiante, quando analisarei os dados do português culto atual.

Se se estabelecer uma comparação entre as observações feitas em estudos sobre a documentação arcaica e os estudos sobre o português atual, será possível verificar o aumento do uso de preposições. Embora os autores dos estudos sobre o português histórico insistam em afirmar que os conectores eram pouco usados por não desempenharem nenhuma função sintática, parece não fazer sentido que esses casos se ampliem substancialmente no português do século XX e que as preposições sejam hoje índices das relações estabelecidas no período sintático.

Uma evidência dessa distorção interpretativa pode ser encontrada em Maurer Jr. O autor demonstra que, a despeito da perda ou redução acentuada do uso da oração infinitiva, não faltam vestígios, por exemplo, na construção de vídeo e de alguns outros

${ }^{9}$ sic 
verbos com o acusativo e o infinito (e.g. vejo-o passar todas as manhãs), e o emprego do infinito final em lugar do supino com os verbos de movimento, por exemplo, misit emere, venit visere, e semelhantes, devia ser muito usual na língua falada, o que explica a sua freqüência já nos poetas da época de Augusto.

$\mathrm{O}$ autor alerta que era bastante freqüente o emprego de infinito no lugar do gerúndio como uma espécie de substantivo verbal indeclinável e talvez seja esse o estágio inicial do infinito preposicionado, que iria ter tão grande importância na conjugação perifrástica ou com valor de infinito. Complementa seu alerta com a indicação de que outros autores já sugeriram esse movimento gramatical no latim ${ }^{10}$.

Ainda segundo Maurer Jr., o que a língua vulgar fez foi reter essa construção, enquanto a língua literária, principalmente na época clássica, a pôs de lado. Como o português deriva da variedade falada do latim, é totalmente plausível supor que a inovação se deu há muito tempo e que, hoje, essa estrutura para + infinitivo pode ter sofrido novos deslizamentos funcionais na língua falada.

Com relação ao espraiamento e conseqüente explicação da transmissão lingüística de construções inovadoras, Coutinho (1974) alega que a generalização por analogia nem sempre é uma boa explicação. Segundo ele, ainda que a língua portuguesa não sinta tanto a ação da analogia, a sintaxe, muitas vezes, não pode ser explicada sem ela, e é na regência que ocorrem os casos mais comuns de analogia sintática. Segundo o autor, casos em que locuções verbais apresentam-se com preposições, como é o caso de prefiro morrer do que viver, ao invés de prefiro morrer a viver, são casos de falsa analogia, por influência de outra locução: “eu antes quero”. Prefere falar em contágio

\footnotetext{
${ }^{10}$ Maurer Jr. refere-se a um autor de nome Perrochat e a outros autores não-explicitados em seu texto. Segundo esses autores, o infinito final, como substituto do supino após os verbos de movimento, é antigo.
} 
de expressão equivalente, o que pode gerar a construção de outra expressão, mas não com a mesma sintaxe.

A base de sua discussão é a estrutura que prescinde da preposição para e, depois, com a habituação desse emprego, para se aproxima do infinitivo e, com ele, compõe o valor de finalidade. São evoluções observadas dentro do latim. Na passagem para o português, nota-se uma expansão dessa estrutura. Não é indefensável que essa mesma construção, em sua trajetória natural, tenha assumido novos valores ${ }^{11}$.

Um questionamento interessante nesse ponto das discussões diz respeito à forma como os gramáticos contemporâneos normatizam esses usos. Como, em grande maioria, os gramáticos buscam abonar as regras com dados oriundos de textos literários, fica a dúvida se essa exemplificação daria conta das mudanças sofridas pelo português histórico. A segunda dúvida refere-se aos deslizamentos funcionais sofridos pela estrutura hoje na língua falada: estariam os grandes autores de gramáticas normativas e de livros didáticos atentos a essas mudanças sintático-semânticas?

\section{Estrutura para + infinitivo nas gramáticas: Normatização}

A partir desse momento, estabeleço um paralelo entre o que os gramáticos dizem a respeito das estruturas para + infinitivo e o que os livros didáticos têm abordado sobre essa questão. O que faço, em outras palavras, é confrontar o tido como o "padrão culto e normativo" com "o que deve ser aprendido" na escola. Seriam os grandes escritores das gramáticas normativas espelho para os guardiões da língua culta?

\footnotetext{
${ }^{11}$ Deslizamento semelhante foi observado na trajetória individual do item para: para < pera $(\operatorname{arc}$. $)<$ per + ad.
} 
Nesta seção, faço uma breve revisão do que diferenciam os gramáticos no que se refere ao foco de estudo, mas, para respondermos plenamente a esta questão, procederemos a alguns testes, cujos resultados serão explanados no capítulo IV.

Para a empreitada de confrontar o padrão culto e o normativo, selecionei as gramáticas de Luft (1978), Cunha \& Cintra (1985) e Bechara (1999), as gramáticas com maior número de edições no Brasil, e os livros didáticos, invariavelmente confundidos com gramáticas pelos escolares, de Cipro Neto \& Infante (1997), Cereja \& Magalhães (2004), Maia (2003) e Ernani Terra \& José de Nicola (2004).

Antes, porém, como ponto de partida das discussões, tomo a Gramática de usos, de Neves (2000), que faz um levantamento exaustivo dos tipos de estruturas correntes no português contemporâneo.

\subsection{Um ponto de partida funcionalista: A Gramática de Usos}

De acordo com Neves (2000), na maior parte das vezes, a estrutura para+infinitivo expressa a relação de finalidade, no entanto, pode estar ligada a um núcleo nominal e, então, se tornar uma oração completiva nominal e não mais permitir a acepção de finalidade.

Embora perceba essas diferenças com relação ao valor semântico das orações, a autora nos fornece também alguns exemplos de orações como tendo o valor de finalidade, mas que, na verdade, fazem parte do conjunto das orações encaixadas como em (1), ou que se distanciam da noção de finalidade provocando o que convencionamos chamar, neste trabalho, de desbotamento semântico, como em (2): 
(1) A leitura serve para que a criança aprenda rapidamente o que não poderia alcançar só (A biblioteca. Ferraz, W.6. ed. Rio de Janeiro: Freitas Bastos, MEC, 1972).

(2) Eu não sabia, que diacho, do que é que me acusavam nem o que teria feito para ser tratado assim (Lobos e cordeiros. Lopes. E. São Paulo: Moderna, 1983).

Em (1), a oração introduzida por para que funciona como argumento da oração anterior, o que justificaria incluí-la no conjunto das orações encaixadas. Já, em (2), a oração introduzida por para +verbo não sinaliza a finalidade da oração principal "o que teria feito". Nesses casos em que não se verifica uma finalidade real, optei pelo rótulo de desbotamento semântico, que, no exemplo analisado, seria causado pela codificação tempo/modo da expressão verbal teria feito.

Neves também relata que as orações finais iniciadas por preposição (em infinitivo) não têm restrição quanto ao sujeito. Há orações com o mesmo sujeito da principal, podendo ou não ser flexionado o infinitivo, para concordar com o seu sujeito. Há orações com sujeito diferente do da oração-núcleo, sendo comum, neste caso, que o infinitivo apareça flexionado para concordar com o seu sujeito. Essa discussão, embora mais detalhada, já foi ensaiada por Said Ali (apresentei evidências disso na seção anterior). Ainda, como os demais, a autora alerta para o fato da alta produtividade de para+infinitivo.

A partir daqui, todos os argumentos empregados pela autora são contribuições exclusivamente suas: se a estrutura para + infinitivo codificar finalidade, a oração que corresponde à principal terá sujeito capaz de exercer controle sobre o evento expresso na final. Segundo a autora, será restrição para o valor de finalidade a expressão de um fenômeno natural na oração principal, a não ser que a esse evento ligue-se, de algum 
modo, à intencionalidade, tal como em: Seu maior desejo é de que nada aconteça, para nada se impor a sua autoridade ${ }^{12}$.

Além de apresentar a grande ocorrência das estruturas infinitivas encabeçadas por para, Neves (2000) ainda acrescenta casos em que essa construção pode não ter a acepção de finalidade, como no caso de estar ligada a um núcleo nominal, caracterizando-se deste modo como completiva nominal: "O entrevero com Maria Mimosa lhe dera tempo para recuperar a sua famosa calma dos momentos de ação". Independentemente de ser finita ou não-finita, há, segundo a autora, a tendência de que os sujeitos sejam correferenciais.

Com relação ao ponto de vista do nível ${ }^{13}$ em que estão construídas as orações finais, Neves separa-as em dois tipos:

a) as que se ligam ao conteúdo proposicional da oração principal ( adverbiais circunstanciais): Esboçou um movimento para seguir em frente ${ }^{14}$.

b) as que modificam o próprio ato lingüístico (adverbiais de enunciação): Para dizer a verdade, não sei o que se passa na cabeça do rei.

Note-se que Neves assevera que há diferença na intenção do falante quando emprega uma ou outra estrutura infinitiva. Seriam usos inovadores os apontados por Neves ou simplesmente perspectivas de análise não-acessíveis aos gramáticos históricos, posto que são privilegiados, no modelo de Neves, tanto a intenção quanto o efeito comunicativo?

\footnotetext{
${ }^{12}$ Exemplo gerado a partir de uma estrutura a fim de que apresentada por Neves.

${ }^{13}$ Neves refere-se às camadas propostas por Dik (1987) em sua gramática funcional.

${ }^{14}$ Exemplo gerado a partir de uma estrutura a fim de que apresentada por Neves.
} 
Um caminho interessante para se reconhecer o estado dessa questão é recorrer ao que se ensina na escola e outra, complementar, é verificar o que produzem os falantes cultos tanto em situação mais tensa e escolar (provas e redações) quanto em situação mais espontânea de língua falada. Nesta seção, lido diretamente com o que se ensina na escola por meio da análise de livros didáticos. No capítulo em que analiso os dados, trato da pertinência dessa discussão sobre incorporação de usos inovadores.

\subsection{O que dizem os gramáticos?}

Consultando Luft (1978), Cunha \& Cintra (1985) e Bechara (1999), verifiquei que as orações infinitivas são pouco recorrentes nos exemplos, e nenhum outro valor é aplicado às orações com a estrutura para + infinitivo, diversamente do que encontrei em Neves (2000).

Em Luft (1978), as orações não-finitas antecedidas por para codificam finalidade. Essas podem também ser antecedidas pelas preposições por e a fim de. Conformando suas explicações às de Luft, Cunha \& Cintra (1985) enfatizam a relevância da conjunção na combinação de orações. Vale ressaltar que os exemplos prototípicos de orações finais para esses gramáticos são aqueles que trazem a locução conjuntiva para que. Não explicitam, como já esperava, nenhum outro valor relacionado às estruturas para + infinitivo. Vai diferir em grande medida a gramática de Bechara (1999), que merecerá maior espaço nesta seção.

Bechara (1999) enfatiza a explicação semântica e não a estrutura pela estrutura. Para o autor, as orações para + infinitivo indicam intenção, objetivo, finalidade do 
pensamento expresso na principal, mas podem assumir outros valores em contextos específicos.

Esse autor ratifica a idéia já explanada pelos gramáticos históricos de que a motivação para o emprego de para+ infinitivo é a necessidade que o falante tem de pôr em evidência o agente do verbo.

O infinitivo sem flexão, segundo o autor, revela que a nossa atenção se volta com especial atenção para a ação verbal, e a flexão serve como recurso de insistência (ênfase por repetição) da pessoa do sujeito. Como exemplo de sua asserção, nos fornece duas sentenças: a) Estudamos para vencer na vida (para vencermos na vida); e b) As crianças são acalentadas por dormirem, e os homens enganados para sossegarem (Marquês de Marica, apud BECHARA, 1999: 286)

O autor, assim como os demais gramáticos, elege como as principais conjunções finais para que, a fim de que, que (para que), porque (para que), e fornece o seguinte exemplo como prototípico: Levamos ao Japão o nosso nome, para que outros mais felizes implantassem naquela terra singular os primeiros rudimentos da civilização ocidental. (Latino Coelho apud BECHARA, 1999:328).

Na seção destinada ao tratamento de regência, o autor tece considerações sobre um tipo de estrutura especial que envolve a preposição para: pedir para. Discute o fato de que o verbo pedir necessita ser complementado por um objeto direto (de coisa) e indireto (de pessoa a quem se pede), conforme exemplificado em: Pedi-lhe (objeto indireto) um favor (objeto direto).

O autor explica com o exemplo que se o objeto direto é um favor (ou equivalente), pode-se acrescentar uma oração adverbial de fim que indique o objetivo 
do favor, como no exemplo: Pediu-lhe licença para sair (ou para que saísse). Neste caso, ainda afirma que esse objeto direto favor pode calar-se, mas o sujeito de pedir terá de ser entendido como o mesmo do verbo da subordinada, para ter sanção tranqüila na norma exemplar, como nos seguintes exemplos: O Antônio pediu-lhe para sair (i.é: o Antônio é quem sairá); Pediu para ajudar a vestir sua filha, mas não o obteve (Camilo Castelo Branco apud BECHARA, 1999: 567).

De acordo com Bechara, a linguagem coloquial aproximou a idéia de pedir que algo aconteça (oração objetiva direta) e trabalhar para que algo aconteça (oração adverbial final), passando a usar a preposição para introduzir a oração, que seria objeto direto do verbo pedir: Pediu para que Antônio saísse em lugar de Pediu que Antônio saísse.

O autor faz uma crítica aos gramáticos, dizendo que os mesmos ainda não aceitaram a operação mental, apesar da insistência com que penetra a linguagem das pessoas cultas. Afirma, ainda, que o novo modo de expressão traz também uma ambigüidade, porque se fica sem saber qual é, na realidade, o sujeito da oração subordinada, como em: Antônio pediu a José para sair.

Bechara assegura que os gramáticos só consideram a expressão correta se o sujeito for Antônio, sob a alegação de que o objeto direto oracional não pode vir introduzido por preposição, mas a linguagem coloquial constrói o período como se o sujeito fosse José, o que é, de acordo com o autor, repudiado pelos gramáticos.

Como se vê, mais recentemente instaurou-se uma divergência no tratamento das estruturas para + infinitivo. Emerge desse fato um questionamento sobre a transmissão 
dessas idéias no ensino de língua portuguesa. Perguntemo-nos, agora, como a escola tem lidado com a estabilidade/mudança observada até aqui.

\subsection{Como a escola tem lidado com essa questão?}

A partir deste momento, faço uma incursão pelos livros escolares e verificarei como é implementada em sala de aula a explicação sobre o valor semântico das estruturas para + infinitivo. Os livros selecionados são os seguintes: Cipro Neto \& Infante (1997), Maia (2003), Cereja \& Magalhães (2004) e Ernani Terra \& José de Nicola (2004).

Em todos os livros didáticos, a análise do valor semântico da estrutura para + infinitivo é de finalidade e a explicação é óbvia: apresentam finalidade para o fato expresso na oração principal.

Cipro Neto \& Infante (1997) associa a estrutura para + infinitivo às orações subordinadas adverbiais finais, que exprimem, nas palavras dos autores, "a intenção, a finalidade do que se declara na oração principal". Segundo os autores, esse valor é codificado mais freqüentemente pela locução conjuntiva a fim de que. Outras conjunções aparecem nesse tipo de oração: para que, que e porque, estas duas últimas mais raramente. Os exemplos apresentados são os seguintes: a) Vim aqui a fim de que me explicasse as questões; Fez tudo para que eu não obtivesse bons resultados; Suportou todo tipo de humilhação para obter o visto americano. Todos os três exemplos são seguidos de uma interpretação dos autores, que substituem o nexo pela locução para que, a demonstrarem que essa é a locução que melhor explica aos alunos a reconhecer uma oração de finalidade. 
Note que os autores incluem um exemplo de oração infinitiva para+obter, embora não tenham descrito o caso anteriormente. Após a exemplificação, apresentam um exemplo extraído de uma peça publicitária: Estão usando mulher pelada até para vender seguro de vida. Essa sentença é seguida de uma explicação destacada: "Para vender seguro de vida" é uma oração subordinada adverbial final.

Com relação ao tipo de exercício do livro, os autores optam por orações independentes que devem ser conectadas num período composto. $\mathrm{O}$ estímulo para a produção de orações finais é do seguinte tipo:

(3) Precisamos formar um time. Assim, poderemos participar do campeonato.

(4) Deve-se investir em saúde e educação. Dessa forma, a situação dos brasileiros vai melhorar.

Os autores esperam que os alunos sejam capazes de incluir o conector final para que. A questão cuja resposta fica suspensa é que tipo de construção é apresentado pelos alunos numa situação como essa. Saber, pelas gramáticas, que para que e a fim de que são os usos normativos mais recorrentemente citados não equivale necessariamente ao que, de fato, é empregado como solução pelos alunos. Retomarei, adiante, essa questão, especialmente porque julgo imprescindível um teste que permita reconhecer a primeira opção dos informantes de uma geração mais nova, pois isso serve de indicativo da direção de mudança efetivamente em curso.

Maia (2003), como os demais, privilegia as orações desenvolvidas, mas enfatiza com exemplo exclusivamente aquela veiculada nas gramáticas como a exemplarmente culta, como em (5). Embora não discuta a existência da estrutura para+infinitivo, inclui nos exercícios de fixação a estrutura observada em (6). 
(5) “Construíram-se diques para que as águas não alagassem os campos”.

(6) "Usávamos o computador para agilizarmos os cálculos".

Outro material didático de grande penetração no meio escolar é o livro de Cereja \& Magalhães (2004). Nele, os autores apresentam o seguinte exemplo: "Tentei de tudo para que ele aprendesse a tocar um instrumento musical", e também nos fornece como exemplo de orações adverbiais reduzidas a seguinte oração retirada de uma propaganda: "Você precisa se comunicar para chegar aonde quer". Como exercícios de fixação, os autores sugerem que os alunos classifiquem as subordinadas adverbiais já destacadas, mas não oferecem nenhum caso de estrutura para + infinitivo. Também oferecem exercícios com a conjunção que, orientando o aluno que indique o valor semântico expresso por essa conjunção nas orações subordinadas adverbiais destacadas. Alertam os alunos para o fato de que a palavra que apresenta diferentes valores semânticos (consequiência, comparação, finalidade, concessão e comparação). Pode-se, desta forma, perceber que, para os autores, o que determina o valor semântico da sentença é a conjunção, por isso sugerem que os alunos classifiquem as orações a partir das mesmas.

Um último material didático selecionado é o de Ernani Terra \& José de Nicola (2004). Tal como nos anteriores, a locução a fim de que é considerada o paradigma para escolares, e o exemplo selecionado é o seguinte:

(7) Os lavradores esperavam a chuva a fim de que não perdessem a colheita.

Já nesse exemplo, vislumbra-se alguma ambigüidade, ainda que tênue: qual a finalidade da espera dos lavradores? a finalidade ou o objetivo é a chegada da chuva. Para dar conta dessa finalidade, a oração deveria ser construída da seguinte maneira: A chuva deveria cair a fim de que os lavradores não perdessem a colheita. 
O período composto apresentado por Ernani Terra e José de Nicola tem em seu interior uma serialização de ações elididas. Originalmente, teríamos três orações: Os lavradores esperavam que a chuva viesse a fim de que não perdessem sua colheita. Os valores relacionados são: os lavradores esperavam (oração matriz de caráter volitivo); que a chuva viesse (oração encaixada na oração anterior e oração-núcleo da oração seguinte); a fim de que não perdessem a colheita (oração hipotática de finalidade). As perguntas que estão em jogo são: Qual o evento necessário para que a colheita não se perca? a espera dos fazendeiros pela chuva? a chuva molhando a plantação? Com a inversão das orações, torna-se ainda mais clara a não-finalidade estabelecida entre as orações, já que o ponto de partida é: Para que os lavradores aguardavam a chuva?

Se o encaminhamento desse raciocínio estiver correto, pode-se hipotetizar que construções finais dessemantizadas poderiam ter emergido da aproximação de uma oração matriz com complemento elidido (num processo de metonímia) de uma oração hipotática sem cabeça (sem oração núcleo). Afinal, orações volitivas associam-se cognitivamente a orações de finalidade. Voltarei a essa discussão durante a análise dos dados.

Com relação aos exercícios de fixação, são selecionadas orações que devem ser encadeadas em período composto com o auxílio de uma conjunção. Também incluem exercícios em que os alunos devem classificar as orações subordinadas adverbiais já destacadas. Nesse rol, não há um único exemplar da estrutura para + infinitivo, ou seja, de uma lista de 18 orações variadas, incluem somente duas com o valor de finalidade, mas com os conectores para que.

Os livros didáticos, acima analisados, apresentam como as principais conjunções e locuções conjuntivas finais "a fim de que, para que e que". Essa convergência 
distancia-se em grande medida do que Neves apresenta: orações finais na forma infinitiva encabeçadas pela preposição para são as mais freqüentes. Nesses livros didáticos não há qualquer discussão a respeito de outros valores que emanam desse tipo de estrutura.

O que depreendo desse breve levantamento é que os usos lingüísticos mais produtivos na língua portuguesa não são explorados nas gramáticas - à exceção de Bechara (1999) - e, provavelmente em conseqüência disso, nem nos livros didáticos, cujos autores preferem espelhar suas explanações em padrões funcionais que já foram alvo de fortes mudanças no português do Brasil.

O peso das informações veiculadas nos livros didáticos na língua em uso na sociedade pode ser auferido por meio da análise de redações de provas vestibulares, situações mais tensas de cobrança do conhecimento adquirido na escola. No capítulo em que analiso os dados, combino uma amostra de redações de exames vestibulares da Fuvest, um dos mais concorridos vestibulares brasileiros. A expectativa é que esse material sirva de eficiente observatório para investigações que lidem com a mudança em curso no português escrito.

\section{Estrutura para + infinitivo: Pesquisas lingüísticas}

Para muitas questões lingüísticas que envolvem a mudança em curso, não basta saber o que é normativo, o que a escola diz ao aluno, o que é o correto, e quais formas são privilegiadas pelo aluno e pelo povo em geral. Resta, ainda, o trabalho de revisar o que outros estudiosos do tema disseram a respeito do fenômeno. Assim, a fim de proporcionar um quadro mais completo para compreensão da estrutura para + 
infinitivo, torna-se necessário consultar os estudos descritivos apresentados pelos lingüistas. É o que faço a partir deste momento.

Nesta última seção, apresento a revisão lingüística do assunto. Para essa tarefa, seleciono Ferrari (1998), Gorski (2000, 2001, 2003, 2004), Dias (2002, 2005), Azevedo (2002), Salles (2003), Lima (2004), Menezes (2004), Silva (2005) e Lima-Hernandes (1998, 2004).

De acordo com Ferrari (1998), as pesquisas em gramática histórica revelam que a mudança semântica é estruturada pela cognição. Baseada nas idéias de Traugott (1982), demonstra que o vocabulário temporal emerge do vocabulário espacial, e em geral assegura que domínios abstratos do significado derivam de domínios mais concretos.

Gorski (2000), desenvolvendo um estudo vinculado à gramaticalização da combinação de orações, toma como ponto de partida a idéia de tripartição dos processos proposta por Hopper \& Traugott (1993): parataxe, hipotaxe e subordinação, tipos distribuídos num continuum que refletem o percurso da mudança lingüística. Ao lidar com o infinitivo, no entanto, defende que nem sempre funciona como oração reduzida, mas como verbo principal fortemente integrado ao auxiliar precedente, como é o caso do verbo 'dar + para', como em: "A gente ia almoçar no grupo, né? Praticamente almoçava porque a gente dava pra repetir, né?” (FLP 18, L350).

Casos como esses, com estatuto funcional mais nebuloso, são rotulados de "híbridas" tal sua condição de opacidade semântica. A autora tenciona evidenciar que o verbo dar, em seu leque polissêmico de realizações, é responsável pelo controle de dependência da oração vinculada. Nesse tipo de oração, não é incomum, segundo a 
autora, que haja superposições (constituintes vistos ora como complementos ora como sujeitos dos respectivos infinitivos), implicando um forte grau de integração da oração infinitiva à matriz. Alguns dados, apesar disso, apresentam o sujeito expresso, um indício de uma menor integração. Depreende-se desse estudo que a correferencialidade é um parâmetro interessante para se reconhecer o grau de integração de orações ${ }^{15}$.

Gorski (2000) também afirma que nos dados analisados, dados extraídos de vinte e quatro entrevistas do banco de Dados do Projeto VARSUL (seção Florianópolis), $32 \%$ das ocorrências exibiam um estatuto sintático não-adverbial (eram orações subordinadas, e não hipotáticas), contrariando a expectativa de que orações para $+I N F$ seriam adverbiais, como informam as gramáticas normativas. Nessas ocorrências ditas subordinadas, a grande maioria trazia como verbo matriz ter ou dar, o que levou a considerar que os diferentes graus de integração verificados decorriam basicamente da natureza sintática e semântica do verbo da matriz.

Gorski (2000,2001) admite que os conectores são muito importantes no processo de combinação de orações e que derivam historicamente de outros itens, dentre eles as preposições, cujo uso, originalmente motivado pelo desejo do falante de ser claro e informativo, pode vir a servir a uma nova função, carregando para esta traços de sua função de origem. Ao lado de seu emprego como ablativo (8) e dativo (9), os empregos mais recorrentes são como preposição para indicar finalidade (10) e como complementizador (11), conforme os seguintes exemplos demonstram ${ }^{16}$ :

(8) Ele foi para São Paulo.

(9) Trouxe o carro pra ele.

\footnotetext{
${ }^{15}$ Essa idéia pôde já ser lida em Lehmann (1998).

${ }^{16}$ Exemplos retirados do banco de dados do projeto VARSUL
} 
(10) Ele nos deu a carta pra todos nós ler (FLP 12. L554)

(11) Ela está ansiosa pra ficar grávida (FLP 20, L1201).

Desse modo, a preposição para caminha num continuum orientado metaforicamente: de um domínio mais concreto (com o sentido relacionado à direção espacial) para um domínio mais abstrato (objeto indireto, finalidade, passando por reanálise como complementizador e relativizador).

Na combinação de orações, pode-se dizer que o traço semântico de finalidade vai se diluindo aos poucos; o vínculo com a matriz vai se estreitando; a preposição para vai desempenhando a função de outros conectores (conjunção e relativo); e passa a ocupar o lugar de outras preposições, como em:

(12) Não tenho vontade de voltar (FLP 21, L345)

(13) (A gente) não tinha vontade pra ir em casa (FLP 02, L864)

De acordo com a autora, são encontradas em Florianópolis construções em que de concorre com para, em contextos modais de possibilidade, fato a ser verificado nos dados de língua falada em São Paulo.

Como se pode observar, a autora expõe que o verbo da matriz tem grande influência na função sintática das orações para + infinitivo. Segundo ela, o verbo ter passa de verbo pleno de posse ou existencial a auxiliar de tempos compostos e, mais recentemente, a verbo-suporte (fruto de dessemantização de V e do SN complemento).

Processo semelhante ocorre com o verbo dar, que passa de verbo pleno de sentido concreto (oferecer, envolvendo deslocamento no espaço) para verbo-suporte, semanticamente esvaziado (por extensão metafórica, perde o sentido de movimentação 
física), de verbo principal estativo com valor de suficiência e possibilidade (significando ser suficiente) para auxiliar modal (no sentido de ser possível). Esse percurso que envolve mudanças na natureza sintático-semântica do verbo reflete-se em diferentes graus de integração das orações combinadas.

Assim, com o verbo ter, para INF comporta-se como relativa (14), completiva nominal (15) e adverbial (16). Desta forma, ter mostra-se como verbo de posse, verbosuporte e existencial. Com o verbo dar, a reduzida de infinitivo parece funcionar como oração adverbial (17), completiva nominal (18), objetiva indireta (19), subjetiva (20) e praticamente integrada em uma locução verbal com auxiliar modal (21):

(14) Ele não se conforma em ter apenas uma casinha pra morar, ele quer uma casinha pra morar no centro. (FLP, 21 L 1153)

(15) Quem não aprendeu é porque tinha uma tendência pra não aprender (FLP 2, L910)

(16) Tinha uma missa pra depois começarem o desfile (FLP 24, L633)

(17) Ele dava tinta pra gente pintar (FLP 1, L1112)

(18) O pai dava liberdade pra gente sair ( FLP 4, L278)

(19) O meu dinheiro dava pra gente viver bem ( FLP 13, L411)

(20) Na hora do pique mesmo não dá pra gente pegar ônibus (FLP 10, L896)

(21) A gente dava pra repetir (FLP 18, L350)

A autora postula que o vínculo adverbial demonstra-se mais frouxo por vincularse à oração matriz como um todo e não a algum constituinte específico. Essas sentenças complexas analisadas podem ser consideradas fortemente integradas, e a oração para+ INF vinculada a um constituinte nominal da matriz é bastante recorrente. $\mathrm{O}$ item verbal que propicia maior integração é ter, dado que as vinculações no conjunto de ocorrências 
com esse verbo se dão preferencialmente num nível sintático mais baixo (como complemento ou adjunto nominal), em oposição às combinações com dar, predominantemente subjetivas ou híbridas, vale dizer, sem estatuto definido.

Gorski, Mittmann e Neves (2003) também analisam construções infinitivas com o verbo ser na oração matriz, na $3^{\mathrm{a}}$ pessoa do singular, seguido de complemento nominal, prevendo superposição de funções e conseqüentemente, a ocorrência de construções de interpretação ambígua.

De acordo com as autoras, as construções $\left[\mathrm{SER}_{\mathrm{P} 3}\right]+\left[\mathrm{N}_{\mathrm{SUB} / \mathrm{ADJ}}\right]+(\mathrm{PREP})\left(\mathrm{SUJ}_{\mathrm{INF}}\right)$ [INF] (COMP/ADV) não apresentam um estatuto sintático claramente definido; antes, comportam-se como construções camaleônicas, sendo identificadas ora como orações subjetivas, ora como predicativas, ora como completivas nominais, apresentando casos de interpretação ambígua de seu estatuto sintático.

Tais mudanças sintáticas parecem envolver fundamentalmente a preposição, que se desenvolve em duas direções distintas:

a) sobre a preposição $d e$ : na estrutura $[\mathrm{N}]+d e[\mathrm{INF}]$, possui mobilidade de algum constituinte nominal deslocado para a posição de sujeito do verbo principal; nesse caso a oração reduzida tende a se configurar como um complemento nominal. Seu uso está mais bem estabelecido no tempo e atribui um caráter de maior integração às orações combinadas, contrariamente ao que postula Lehmann (1988) com seus parâmetros de entrelaçamento. Assim, a preposição de é conector responsável pelo maior entrelaçamento das orações; 
b) sobre a preposição para: com a emergência de uso adjacente a $\left[\mathrm{N}_{\mathrm{ADJ}}\right]$, a facilidade da mobilidade dos elementos sob seu escopo é evidenciada. Sua presença resulta numa construção (possivelmente subjetiva) menos integrada e menos gramaticalizada.

Dessa forma, a preposição de é prototípica para complementos nominais, o que, segundo as autoras, seja isso que esteja impedindo o seu deslocamento, rompendo assim a integração entre o adjetivo e seu eventual complemento. Já a preposição pra, típica de indicação de finalidade em constituintes com valor adverbial, portanto potencialmente deslocáveis, favorece o rompimento da ordem canônica:

(22) Pra chegar até o Rita Maria a pé seria fácil (FLPJ2L1073)

(22a) Seria fácil pra chegar até o Rita Maria a pé.

(22b) Seria fácil de chegar até o Rita Maria a pé.

(22c) ? De chegar até o Rita Maria a pé seria fácil.

Em pesquisas realizadas por Gorski (2003), o elemento nominal posposto ao verbo finito é o adjetivo no século XX e o substantivo era mais utilizado no português arcaico. O uso da preposição já ocorre desde o século XVI, e embora o conector parece ter perdido espaço na escrita ao longo dos anos, ocorre um aumento do uso da preposição para nos dados de fala (aproximadamente do século XX) e da escrita (século XVI). A preposição para vem tendo seu uso intensificado diante de infinitivo, porém migrando do contexto [Nsub] + para [INF] para o contexto [Nadj] + para [INF]. Vale salientar que, nos dados escritos, todas são regidas por um Nsub e nos dados de fala por um Nadj:

(23) Porque você estudou, com um diploma na mão é mais fácil pra você se ajeitar, pegar um serviço aqui ou lá (FLP02L1310). 
(24) Em clube assim, não é um ambiente muito bom pra namorar (FLPJ 1 L891).

(25) Cousa he pera prezar;/Que quem tal amigo tem/Não se deve de temer. [1518] (Vicente 1965, p. 434).

De acordo com a autora, no contexto como (24), a preposição parece estar mais ligada ao verbo que vem depois dela, funcionando como uma espécie de locução. Também supõe que nesses contextos em que [Nadj] acompanha o substantivo, tenham propiciado a emergência de para junto a adjetivos.

Gorski também verifica que casos em que um constituinte da oração subordinada é promovido à posição de sujeito da principal podem provocar ambigüidade na análise do estatuto sintático da oração infinitiva, que passa a ter um comportamento muito semelhante ao de complemento nominal. Outra asserção interessante é aquela relativa à preposição $p r a$, que apresenta maior probabilidade de ocorrer na anteposição da oração infinitiva, tendo reflexos na reorganização do enunciado, afetando o estatuto sintático de seus constituintes.

Em pesquisas posteriores, Gorski e Neves (2004) têm como foco também as orações em Ser $+\mathrm{N}+$ (prep) INF numa abordagem sincrônica. O comportamento da preposição + infinitivo pode funcionar como complemento nominal, processo que resulta em usos híbridos com interpretação ambígua, como nos mostra no exemplo (26):

(26) Era uma dificuldade ( $p r a)$ (mim) chegar na aula, né? (FLP 18L123).

É um caso interessante para estudos sobre gramaticalização, posto que a ambigüidade é forte indício de um processo de mudança. De acordo com os estudos da autora, nos dados analisados, em $81 \%$ dos casos não houve material intermediário entre $N$ e $I N F$, a não ser a preposição, e um eventual sujeito de $I N F$, o que aponta para certa 
cristalização em seus constituintes. A maior incidência preposicional relaciona-se com de. Ocorre uma variação no uso das preposições, pois algumas construções aceitam somente pra, outras somente de, e algumas aceitam ambas. Fica assim evidenciada a dificuldade em avaliar as possibilidades potenciais de ocorrências de construções, o que é um indício de que está ocorrendo um processo de mudança.

O que está subjacente a essa análise realizada por Gorski, em seus vários estudos, é a idéia de Lehmann (1988) quanto ao maior grau de integração atribuído a construções sem preposição e com sujeito expresso, especialmente porque a autora identifica dados em que a preposição (conector) revela-se responsável por uma integração mais estreita.

Com relação à ordem da oração para + final, a anteposição só é possível com pra, provavelmente por ser uma preposição típica de finalidade, com valor adverbial, potencialmente deslocáveis. Sob o ponto de vista das variáveis sociais, a autora observou que informantes com grau colegial são os que menos usam de e os que mais usam pra. Já entre informantes com baixa escolaridade, verificou-se a maior incidência de ausência de preposição.

Suas considerações finais revelam que há um movimento no sentido de preenchimento do sujeito de INF e inserção de preposição, com preferência por de, mas com incidência relativamente alta de pré-construção tida como inovadora. A preposição de é responsável por um grau maior de integração, pois restringe a mobilidade da $I N F$, sendo analisada deste modo como completiva nominal. Com o deslocamento de SN para a posição de sujeito (tendência geral ao preenchimento do sujeito no PB), a oração de INF deixa de ser subjetiva, firmando-se na maioria dos casos como completiva nominal, atribuindo à mesma um grau maior de integração, preservando-se inclusive a 
ordem canônica: $\mathrm{S}+\mathrm{V}+\mathrm{Complemento}$. Ao final, a autora alerta para a necessidade de se aprofundar os estudos com outros e mais amplos conjuntos de dados.

Lidar com cesuras oracionais foi tarefa também de Lima-Hernandes (2004), ainda que tomasse como ponto de partida as orações de base temporal. Aqui, restrinjo a síntese aos critérios priorizados para revelar dados inovadores sob o ponto de vista da gramaticalização da combinação de orações.

De acordo com Lima-Hernandes (1998), o discurso não é constituído de unidades isoladas, mas de unidades informacionais ligadas de modos diferentes. Essas unidades são chamadas, na literatura, de cláusulas ou orações, que são ligadas umas às outras, estruturalmente ou semanticamente, de forma mais ou menos lassa, constituindo, numa sequiência maior, períodos compostos ou sentenças complexas.

Reconhece, entre seus dados do português carioca e do português popular de São Paulo, algumas construções híbridas capazes de gerar ambigüidades interpretativas ou possível acúmulo de noções em um único tipo de oração. Após analisar um conjunto substancial de dados, propõe que, entre parataxe e hipotaxe, há conjuntos de orações combinadas por processos intermediários. O mesmo se dá entre hipotaxe e encaixamento.

Azevedo $(2002)^{17}$ assume a idéia de que a colocação das orações finais no período está sujeita a pressões de caráter textual e pragmático. Um dos condicionadores seria a ordem temporal dos fatos ocorridos (iconicidade): a idéia de finalidade pode indicar perspectiva de futuro, o que condicionará a escolha da posição final na oração. O estatuto informacional, então, também compõe o quadro dos fatores condicionadores:

\footnotetext{
${ }^{17}$ Para esta pesquisa, o autor constitui um corpus a partir de exemplos retirados de textos escritos na norma culta, que cobrem um período de aproximadamente sessenta e cinco anos.
} 
principal + final é a ordem básica, por se tratar em sua maioria de uma informação nova.

Desse trabalho, sobressai a idéia de que somente pode assumir o valor de finalidade, em toda a sua extensão, aquela oração que vier posposta a sua principal. Se vier codificada anteposta à principal, a finalidade sofre dessemantização, gerando duplo valor proposicional entre finalidade e condição. Esse resultado será alvo a ser checado com relação às amostras paulistas nesta dissertação.

Também interessada na ordem está Dias (2002), ao investigar a correlação entre ordem das finais e funções discursivas ${ }^{18}$. Segundo a autora, as cláusulas de finalidade codificam um movimento de uma origem para um objeto da finalidade, no mundo das intenções, e esse deslocamento da origem > objeto da finalidade pode ser marcado por um sujeito agentivo, experienciador ou por um locutor. Esse deslizamento reflete-se na classificação dessas orações: cláusulas de finalidade integram ou não o conjunto das hipotáticas. Caso assuma o estatuto de uma hipotática discursiva, funcionará como tópico sentencial e estabelecerá função coesiva tanto das informações que as sucedem como das que as antecedem, ocupando assim as posições antepostas (introdutoras de tópicos, mantendo coesão discursiva) e as mediais (em que o falante apenas põe em evidência a informação). Caso assuma o estatuto de uma hipotática canônica, especificará e delimitará a informação contida na cláusula núcleo, permanecendo posposta. No conjunto das [-hipotáticas], encontram-se cláusulas parentéticas e de adendo, as quais não se vinculam a cláusulas-núcleo e se caracterizam pelo predomínio de funções textual-discursivas.

\footnotetext{
${ }^{18}$ A autora investiga dados de fala, extraídos de transcrições de fala informal, Projeto Censo do Rio de Janeiro e textos da língua escrita, publicados no encarte MAIS!, Folha de São Paulo.
} 
Desta forma, fornece-nos em (27) e (28) exemplos de orações hipotáticas discursivas nas posições antepostas, quando possuem a função tópica, sustentando e auxiliando a coesão discursiva; em (29), na posição medial, quando exercem a função sintática de encaixada, estando desta forma impossibilitada de se deslocar devido ao conector mas; no exemplo (30), a hipotática de finalidade somada à cláusula-núcleo funcionaria como base de sustentação do parágrafo; no exemplo (31), em que se têm cláusulas hipotáticas de finalidade canônicas, nota-se que o papel semântico é superior ao discursivo; no exemplo (32), a posposição dessas cláusulas provoca uma interpretação de que funcionem como cláusulas de adendo, constituindo unidades entonacionais; e, por último, o exemplo (33) em que temos cláusulas de finalidade parentéticas codificando a interferência do interlocutor na seqüência do fluxo discursivo:

(27) Willian Faulkner voltou para os Estados Unidos, numa tarde de Sábado, dia 14 de agosto. Para confortá-lo no retorno, levou consigo, como presente dos brasileiros, uma garrafade pinga (Encarte MAIS!, Folha SP).

(28) L1 Ou então, (Ir) lá/em Marechal Hermes também tira a carteira. Para renovar é só levar a carteira antiga, na mesma hora já traz outra carteira (EST)

L2 E não precisa de retrato, nada, pra renovar?

L1 Não, não, aí tem - leva o retrato datado.

L2 E Então, é só o retrato e a pessoa.

(29) Felinto, que nasceu em Recife, diz não ter método para escrever. 'De repente me vêm partes inteiras do livro e eu consigo desenvolver o eixo central. Mas, para brotar, a narrativa leva um tempo que nunca é determinado por mim. É o tempo do próprio livro, sobre o qual não tenho domínio (Encarte MAIS!, folha SP).

(30) Folha: Onde fica o escritório de João Cabral de Melo Neto? 
Escritor: Não existe mais, diz o maior poeta brasileiro vivo. Eu estou sem escrever, compreende? Meu último livro saiu em...Fiz uma operação muito séria no intestino, e fiquei 70 dia na UTI, em 1993, estava cego. De forma que não escrevo mais. Eu, para escrever, preciso ver. Não adianta eu ditar para alguém, porque eu preciso ver a minha letra construindo o verso... (Encarte MAIS!, Folha de São Paulo: O escritor)

(31) Eu, quando eu era moleque, eu engraxei, saía para engraxar, engraxava aqui em Bonsucesso. Escondidinho eu ia para Copacabana. (Censo?RJ).

(32) Que eu resolva, aí embola tudo. Aí confunde tudo e, aí, eu falo assim: 'Vem, então é melhor a gente não sair'. Nem sai eu, nem sai ele para ir à praia. Para ir a lugar nenhum, para fazer nada.'

(33) Ora, esse novo Brasil, que ele chama americano, para indicar uma especificidade que o afasta do ibérico, era sobretudo o Brasil meridional transformado pela imigração, sendo curioso que não tenha feito referência ao imigrante.

Assim, enquanto se enquadram na posição intercalada (parentéticas), algumas cláusulas representam a fala do locutor ao acrescentar informações consideradas relevantes e ocupam a posição intercalada, adquirindo assim um caráter pragmático; já, as cláusulas de adendo representam adição de informações, ocupando posposições em relação à outra informação.

Nessa relação de cláusula hipotática + cláusula núcleo, a autora defende que se podem ter as duas cláusulas como base de sustentação do parágrafo e que as cláusulas hipotáticas canônicas exercem um papel mais semântico do que discursivo, ocorrendo uma delimitação de informação na cláusula núcleo.

Dias traça um paralelo entre algumas cláusulas que poderiam ser consideradas de finalidade, mas que podem também apresentar características de meta-cláusulas (intenção do falante em trazer o ouvinte para seu discurso, como em "para você ver"). 
Nesse caso, é o contexto que auxilia o falante a separar as cláusulas infinitivas com para em codificadores ou não-codificadores de finalidade:

(34) Você não vai deixar ele te prejudicar (...) Se ele foge, ele vai me prejudicar, via dizer que eu cobri ele. Então é o seguinte: negócio de - como é que é? Se me der uma idéia, eu sentir que não tem nada a ver, eu deixo o cara ir embora. Qual é, eles me conhece, sabe que eu sempre fui amigo. Pô, para você ver, onde você chegar aqui, ninguém- não encontra um inimigo meu (Censo/ RJ: Robs, 22 anos).

Em trabalho posterior, Dias (2005) mostrou divergências e convergências entre as cláusulas hipotáticas canônicas e discursivas. As orações canônicas ocupam a posposição e delimitam a informação contida na cláusula-núcleo, e as discursivas ocupam as posições anteposta e medial, e podem estabelecer coesão com as informações que as sucedem, não estando limitadas apenas à cláusula-núcleo. A autora observa a necessidade de que as posições antes e depois do verbo sejam preenchidas a fim de facilitar a identificação dos argumentos das cláusulas reduzidas de infinitivo, já que categoricamente apresentam-se com a estrutura para + infinitivo. No entanto, esse preenchimento é realizado na ordem não-marcada ( $\mathrm{S}$ V O), uma vez que há mais SNs plenos na função de sujeito na língua escrita, os quais auxiliam na ativação da memória.

Dias apresenta os argumentos de Mateus et alii sobre a interpretação relativa depreendida a partir da estrutura para + infinitivo. Segundo Mira Mateus et alii, haveria uma articulação possível de um núcleo com $t e r+S N$ ou $s e r+A d j$, assim configurando uma oração relativa (substituída por que): Eles têm uma faca para cortar o queijo > Eles têm uma faca que corta o queijo. Na verdade, Dias (2001) discorda desse argumento, pois seus dados permitem afirmar que nem todas as orações com esse tipo de articulação podem ser parafraseadas por uma cláusula relativa. 
Ainda sobre outras funções, Thompson \& Longacre (1994, apud DIAS, 2001) comparam as cláusulas finais com as causais, dado que ambas codificariam semanticamente uma explicação acerca de um dado estado ou de uma determinada ação, no entanto, as finais expressariam um evento que seria realizado num período de tempo diferente daquele codificado na cláusula-núcleo. As causais, por sua vez, expressariam um evento que seria realizado no mesmo período de tempo da cláusula-núcleo. Essa aproximação provavelmente derive de estruturas para+infinitivo, como apresentado anteriormente, em que um processo metonímico aproxima dois tipos de orações, separadas originalmente por uma oração encaixada.

Ainda sobre o tema, encontramos o trabalho de Lima (2004), que aplica os critérios sugeridos por Lehmann para avaliar a integração sintática entre as orações 'principal' e 'subordinada'. A autora registra ocorrências em que apresentam contorno entonacional diverso e também orações produzidas por diferentes locutores numa seqüência construída cooperativamente, tal como o seguinte exemplo:

(35) L2- eu já vi até que ela anda dando esse golpe aí sabe?...

L1- pra ficar com o dinheiro...

Orações complexas construídas cooperativamente podem de fato emergir em situação de conversação espontânea e, apesar de não ter notícias de estudos sobre esse tipo de estrutura, farei uma incursão pela amostra interativa para verificar sua ocorrência, ainda que não seja este o alvo principal deste estudo.

Com base na noção de "idea unit" apresentada por Chafe (1980), Decat (1999) defende que a ocorrência de 'orações adverbiais' em contornos entonacionais separados ou diversos - fenômeno ao qual ela chama de "desgarramento" - somente é possível nas 
orações não-encaixadas, justamente porque constituem um "unidade de informação" à parte.

De acordo com a autora, ao contrário do que se supõe, essas orações não representam o grau máximo de independência estrutural na relação núcleo-adverbial. Embora a gramática tradicional não cogite a possibilidade de uma adverbial aparecer sem sua oração-núcleo, a combinação de duas orações é mais freqüente do que as adverbiais isoladas, que, sozinhas, constituem enunciados completos e aparecem não só em textos orais, mas também em textos escritos, tendo, desse modo, uma grande relevância interacional.

Ainda a autora ressalta que, deste modo, não se podem classificar as orações subordinadas adverbiais como orações sem 'relevância informativa', pois, nesses casos, o conteúdo expresso é a informação principal. Essas são as bases para que chegue à conclusão de que a ocorrência de construções adverbiais desatreladas de uma oração matriz, quer em textos orais, quer em textos escritos, configura-se como um recurso discursivo.

Esse recurso discursivo seria uma estratégia adotada pelo falante para que o seu interlocutor seja levado (a autora prefere 'obriga') a envolver-se mais na situação interativa, cooperando na construção dos sentidos. A idéia de que a 'bagagem semântica' resultante do inter-relacionamento entre uma matriz e uma adverbial seja preexistente não satisfaria, pois essa bagagem derivaria da situação interativa (e a partir dela), quando o locutor e o interlocutor construiriam em parceria o texto. 
Menezes (2004) é outra autora que se detém na análise da construção para + infinitivo. Ela identifica ${ }^{19}$ as diversas funções sintáticas que essas construções podem assumir, tomando como ponto de partida a função prototípica de adverbial de finalidade. Discute, no entanto, a possibilidade de assumir novas funções mediante motivações semânticas e discursivas, as quais devem ser estudadas dentro de uma abordagem pragmática. Parte do pressuposto de que as construções adverbiais para + infinitivo têm, de modo geral, a função pragmática de "orientar o discurso", favorecendo, se anteposta, o valor de condição. A autora analisa a construção para + dar sobre a qual assevera a atuação de forte integração, como uma espécie de predicado fixo. Seu objetivo é evidenciar que a nominalização (o infinitivo verbal), a despeito de derivar, em termos de valência, outra oração: a oração desenvolvida correspondente, não daria conta de explicar a diferença funcional, pois

a) Observemos que não há sujeito sintático compartilhado, como se esperaria numa construção subordinada reduzida. Então, não é possível estabelecer uma relação anafórica com um referente para o sujeito zero do infinitivo, pois a construção avança na escala de dessentencialização, em que o infinitivo fica [- verbal] se apresenta, tal como em (36):

(36) ...quando um quer falar, um, um tem que falar mais alto do que o outro senão não dá pra falar... (NURC C90 M1, 424)

b) a relação entre o infinitivo e seu sujeito e a relação entre a construção infinitiva e o contexto funcional são importantes para determinar se o infinitivo se aproxima ou se distancia de um predicado verbal prototípico.

\footnotetext{
${ }^{19}$ A autora utiliza amostras de língua falada culta, com 820 ocorrências de entrevistas pertencentes ao conjunto de dados do Projeto NURC/RJ, e com uma amostra de língua escrita, com 820 ocorrências da mesma estrutura, registradas em 330 crônicas de Arthur Xexéo, que foram publicadas pelo Jornal do Brasil nos anos de 1996 e 1998.
} 
A autora discute o distanciamento das orações pra+infinitivo com relação a função adverbial de finalidade, tal como em (37), a qual, segundo a autora, representa o nível mais alto extremo da estrutura hierárquica da frase, com a função de adverbial de enunciado e em (38), onde a construção é fixa a verbos - construções com verbo dar, estar e ter:

(37) Para começar, houve o que se chama nas escolas de Jornalismo de "ruído de comunicação". Madonna não entendia - ou não entendia - o inglês de Marília Gabriela (JB/AX,23/09/78)

(38) ...então eu realmente fiquei com medo mas... deu pra passar... (NURC90)

Em trabalho anterior, Menezes (2001) havia tratado do verbo ter com valor de posse na oração principal. Observou, naquela empreitada, que tanto em amostras de oralidade quanto de escrita as construções ligadas a nomes ocorrem com significativa frequiência. Notou também que a atuação do esquema predicativo desse verbo determina que o complemento passe a compor o predicativo, gerando força predicativa, como no seguinte exemplo:

(39) ...eu não tenho...diria...palavras vocabulário pra poder descrever ela...(NURC90)

Os pressupostos teóricos dessa pesquisa eram fundamentados em Dik (1989), que faz a distinção entre satélites e argumentos e, mais do que isso, dá relevo às funções comunicativas e ao papel e bagagem pragmática dos interlocutores. Nessa perspectiva, a autora estuda a atuação das regras de formação mais relevantes para a identificação do contexto funcional dessas construções.

No percurso de sua investigação uma dificuldade se impôs: as categorias nem sempre eram distinguidas com clareza. Como todos os outros autores que analisaram para +infinitivo, também Menezes buscou critérios em Lehmann (1988) em especial no 
que se refere ao grau máximo de integração: a dessentencialização. Pôde observar então que, no processo de redução (em valência) ocorreria uma alteração no significado do predicado verbal, e o verbo receber, sem objeto, assumiria no contexto o valor de “receber visita com elegância”. O exemplo era o seguinte: “...eu sou de família...aquele pessoal que tinha status... pra receber ..."

Como o foco de seu trabalho estava centrado nas relações de transitividade nos contextos com verbo ter, Menezes mostra que outros fatores estão relacionados ao processo de aproximação ou de afastamento da construção infinitiva iniciada por para em relação a uma estrutura com função semântica de finalidade:

1) Nome que complementa o verbo ter apresenta maior grau de agentividade $=$ maior aproximação da função de finalidade. Construções de finalidade prototípicas requerem uma principal com sujeito capaz de exercer controle sobre o evento expresso na oração adverbial. Tratando-se da encaixada no Nome com verbo ter na matriz, já que esse verbo seleciona sujeito (-) controlador, o nome (+) agentivo funciona como sujeito: “Tom Cavalcante acaba de ganhar o direito de ter dois redatores para criar piadas...”.

2) Categorização [+] instrumento caberá aos nomes que apresentarem como algo [+/- abstrato] que possibilitaria a realização de algo. A possibilidade não realizada e expressa pela infinitiva iniciada por para: grau mínimo de afastamento de finalidade: “... eu não tenho conhecimento técnico pra te dizer...".

3) Predicado derivado de verbo: força predicativa é reforçada pelas relações de transitividade do verbo ter: “...não tem permissão pra voar...” 
4) Predicado composto fixo nas combinações lexicalizadas (ter + objeto + pra + infinitivo): grau muito baixo de transitividade do verbo ter, ficando difícil identificar se o objeto é ou não afetado, e de definir o grau de oracionalidade da construção infinitiva: "Seleção Brasileira tem tudo pra ganhar"

5) Predicado derivado da expressão ter que fazer algo(> ter algo pra fazer) : mantém-se no campo da necessidade ( modalidades alética/deôntica).

6) Construção equivalente a uma construção relativa : A infinitiva iniciada por para funciona como satélite em relação ao nome (objeto) : “...ele deve realmente não ter lugar pra ficar e... então....(= lugar onde ficar).

A autora conclui que a variedade de tipos de construção ter+nome + pra + infinitivo, com freqüência mais expressiva na oralidade, corroboraria a noção de predicados derivados, apoiando-se na noção de transitividade, como fenômeno continuum e não-estável.

Os graus de aproximação/distanciamento propostos pela autora podem se tornar ferramentas interessantes para a análise de alguns dados híbridos das amostras que compõem o corpus desta dissertação, daí termos exposto em maior detalhes o encaminhamento de sua análise.

Dois outros autores analisaram a estrutura para + infinitivo. Refiro-me a Salles (2003), com a análise de dados da variedade européia do português, posteriormente confrontada com a variedade brasileira, e Silva (2005), com amostra do espanhol.

Salles (2003) analisa, por meio da correlação entre o subjuntivo e o indicativo, a distinção entre orações subordinadas e a influência da sintaxe em construções 
infinitivas. Em trabalho anterior (SALLES, 1999) ${ }^{20}$, a autora já havia demonstrado nas variedades do nordeste brasileiro, uma estratégia alternativa para encadear efeitos lógicos da oração infinitiva introduzida pela preposição "para": o emprego de sujeito oblíquo agrupado: "Maria disse para mim pro menino sair". O que a autora notou é que a recorrência dessa estrutura associada à preposição (daí a morfologia oblíqua no pronome) favoreceria a perda de flexão.

Esse foi o ponto de partida para seu estudo de 2003, quando propõe que construções infinitivas com para, como ilustrado pelo exemplo (40), encadeiam modalidades irrealis, com a neutralização da oposição morfológica entre o indicativo e o subjuntivo.

(40) a. Maria quer para mim/pro menino sair

Maria wants for me/for-the boy leave- INF

'Maria wants (for) me/the boy to leave'

b. Maria disse para mim/pro menino sair

He said for me/for-the boy leave- INF

'Maria told me/the boy to leave'

A análise contrastiva levou a autora a reconhecer que a ausência de inversão de sujeito afetaria o efeito de sentido nessas orações. Os traços distintores das variedades seriam a ausência de verbo auxiliar, a inversão de sujeito e o fato de predicados epistêmicos não serem encontrados com infinitivos flexionados, além de uma oração finita com um indicativo encadear modalidade irrealis. Na ausência de inversão de sujeito na variedade brasileira, os predicados são somente encontrados com a ordem SV, e as orações são adjuntas e subjetivas.

\footnotetext{
${ }^{20}$ Apud Salles (2003).
} 
Em seu artigo, Salles cita Madeira (1995), que afirma que orações infinitivas sofrem inversão obrigatória com predicados epistêmicos (PE). Nesses casos, a interpretação temporal deriva de sua posição de complemento.

Salles expõe a idéia de Fischer (1988, apud JARAD 1997) sobre a evolução das construções encabeçadas por para (for/to) em inglês: envolvem reanálises diacrônicas da preposição for na posição de complemento, que começou com [DP para VP]. A autora nos fornece como exemplo construções como: "Mary expects John to win". Assim, o objeto do predicado matriz é interpretado como um argumento de infinitivos agrupados, seguindo: i) perda gradual de flexão verbal; ii) rigidez da ordem das palavras; e iii) mudança de SOV para SVO.

Em Jarad (1997), o argumento apresentado para essa mudança é que a primeira reanálise diacrônica teria ocorrido no século XII e este teria sido o gatilho para a perda do caso dativo (objeto indireto). Essa perda, por conseguinte, teria preparado o caminho para a introdução de preposições (to/for) que permitiriam a interpretação benefactivo. A segunda reanálise teria ocorrido no século XVI a partir de uma ambigüidade decorrente das estruturas em que sintagma preposicionado é parte do predicado matriz ou alternativo e em outra leitura geraria uma interpretação em que o sintagma preposicionado é o sujeito da oração infinitiva. Ilustra essas construções o exemplo (41):

(41) a. It's pleasant for the rich for the poor to do the hard work

b. It's pleasant [BENEF for the rich] [SUBJ for the poor] to do the hard work

Apesar de haver diferenças entre as variedades do português no que se refere à escolha da preposição que marca o dativo [o português brasileiro introduz o dativo com a preposição para (for) e a variedade européia faz uso da preposição $a$ (to)], esse 
contraste não é somente lexical. Ocorreriam outras diferenças morfológicas nos usos de acusativo e de pronomes objetos dativos. Salles identifica uma similaridade entre o PB e o inglês: a posição de complemento seria lexicalizada e permitiria a fusão com para, sinalizando então uma estrutura necessária (modo não-suficiente), o que determinaria a condição para permitir o sujeito agrupado: na ausência da flexão do infinitivo seria, então, permitida a preposição. Como se pode depreender desse artigo, há aproximações e distanciamentos entre variedades se tomarmos como ponto de análise a estrutura para+infinitivo.

A fim de ampliar a visão sobre estudos com esse tipo de construção, recorri ao trabalho de Silva $(2005)^{21}$, que analisou as orações finais no espanhol. Partindo do exemplo: "Los libros son para estudiar", mostra que o foco de observação atua como um constituinte da oração principal, uma porção importante para que o enunciado fique completo.

No espanhol, quando o sujeito do verbo principal é distinto do sujeito do verbo subordinado, a única construção permitida é o uso do modo subjuntivo após o nexo final. Desse modo, para ter uma oração reduzida em para + infinitivo, o sujeito do verbo principal deve ser o mesmo do verbo subordinado. Notemos que, apesar de chamá-la de circunstanciais, Silva frisa a relevância de seu conteúdo para a porção informativa e também a relevância do critério de identidade entre os sujeitos.

Talvez a trajetória desse tipo de construção esteja em desenvolvimento desde há muito tempo nas línguas românicas. É o que se pode depreender das observações tecidas por Epiphânio Dias (1970), quando afirma que um dos fatos mais notáveis

\footnotetext{
${ }^{21}$ seguindo a Real Academia, Silva prefere chamar as orações subordinadas adverbiais de circunstanciais.
} 
relativos à sintaxe do infinitivo nas línguas românicas é justamente a construção de preposições com o infinitivo.

Esse autor (DIAS, 1970:218) argumenta que, em português, as preposições acompanham as orações infinitivas (preposição + infinitivo) desde há muito tempo não só no português, mas também em outras línguas românicas. Segundo ele, esse emprego remontaria ao século VIII, quando, no baixo latim, o emprego de preposições com o infinitivo já apareciam em textos que ascendem as primeiras décadas.

Segundo o autor, o infinitivo precedido de para, empregado predicativa ou atributivamente na passiva ou na ativa, em sentido, aparentemente passivo, exprime aquilo de que uma cousa é digna ou aquilo que lhe há de acontecer: "he muyto pera sentir. Não há cousa pera ouvir como Reclamações de amantes agravados. Mais era eu pera guardada",22.

Além disso, também é empregado para exprimir capacidade: Mas tu, de quem ficou tão mal pagado/ Hum tal vassalo ó Rei, só nisto inico,/ Se não és pera dar-lhe honroso estado, / He elle pera dar-te hum reino rico. (Lus.,X,25, apud E. DIAS, 1970: 231). Lista, ainda, como finais as conjunções para que, porque, por tal que, explicando que porque, tão freqüente no português arcaico, está fora de uso.

A impressão que se tem é que se percorre a história de um tipo de construção como se uma grande hélice impusesse sua força centrípeta em ação: a sincronia pode apresentar boiando em seus dados variados os valores históricos, ainda que considerados em desuso; da mesma forma, a emersão de funções inovadoras é impulsionada por mecanismos atinentes à gramaticalização.

\footnotetext{
${ }^{22}$ Epiphanio Dias (1970), pág, 231
} 
No próximo capítulo, apresento uma análise dos dados oriundos de amostras variadas do português dos séculos XX e XXI. No capítulo subseqüente, proponho um teste sobre conexão de orações, cujos resultados guiarão as discussões sobre a incorporação dos conhecimentos normativistas apresentados pelo ensino formal. 


\title{
CAPÍTULO III
}

\section{AMOSTRA DE LÍNGUA FALADA ANÁLISE DOS DADOS}

\begin{abstract}
Neste capítulo, apresento inicialmente informações sobre as amostras que constituem o corpus de língua falada desta pesquisa. Num segundo momento, apresento os critérios que nortearão a descrição dos padrões funcionais oracionais da estrutura para + infinitivo, o que consolidará posteriormente a análise quantitativa desses mesmos padrões. Ainda nesta seção, discutirei a pertinência de se falar em ambigüidade interpretativa a partir dos padrões funcionais com farta exemplificação, ao mesmo tempo em que retomo a explanação sobre a atuação da metonímia apresentada na seção em que evidenciei a transmissão da normatização por meio dos livros didáticos.
\end{abstract}

\section{LÍNGUA FALADA: CONSTITUIÇÃO DO CORPUS}

A língua falada popular não deve ser vista como problemática e como uma violação da língua literária ou mesmo do padrão culto, mas, sim, como uma variedade que não refreia os usos inovadores (cf. MAURER JR., 1962). Como a variedade sob estudo é a culta e já demonstra muitas inovações em relação ao que a normatividade divulga, toda cautela é pouca para lidar com a variedade dita culta, especialmente porque a distância entre o que se aprende e se divulga está já bastante acentuada do que se emprega em situações reais e espontâneas.

Para a tarefa de análise dos dados, foi selecionada uma amostra contendo seis diálogos entre dois informantes paulistanos (D2), num total de 7 horas e 27 minutos de 
gravação. Os diálogos pertencentes ao $\operatorname{corpus}^{23}$ são estruturados por informantes com graus diferentes de intimidade, com um tempo suficiente para que as falas pudessem ganhar um grau maior de espontaneidade.

Com esses cuidados e o objetivo maior de disponibilizar um material o tanto quanto possível próximo da realidade oral, esperavam Castilho e Preti (1987) que a comunidade científica brasileira tivesse em mãos uma maior homogeneidade possível, de modo a permitir análises pelos mais diferentes especialistas de áreas também distintas.

Os diálogos estavam previstos para serem desenvolvidos em 80 minutos, com informantes de diferentes faixas etárias, agrupados em três faixas: informantes da primeira faixa etária (25/35 anos), da segunda faixa etária (36/55 anos) e da terceira faixa etária (mais de 56 anos), conforme apresentado na tabela seguinte:

\section{Quadro 1: Distribuição dos informantes - Português culto de São Paulo}

$$
\begin{array}{cc}
\text { D2/343 - } & 1^{\text {a }} \text { faixa etária - feminino + masculino } \\
\text { D2/62 - } & 1^{\text {a }} \text { faixa etária - masculino + masculino } \\
\text { D2/255- } & 2^{\text {a }} \text { faixa etária - masculino + masculino } \\
\text { D2/360 - } & 2^{\text {a }} \text { faixa etária - feminino + feminino } \\
\text { D2/396- } & 3^{\text {a }} \text { faixa etária - feminino + masculino } \\
\text { D2/333 - } & 3^{\text {a }} \text { faixa etária - feminino + feminino }
\end{array}
$$

O mais importante critério para que o informante se enquadrasse no perfil de falante culto era, no interior do Projeto NURC, a escolarização (nível superior). Assim, todos os informantes eram representantes do "dialeto social praticado pela classe de prestígio" e esse uso constitui o que se chama norma lingüística objetiva.

\footnotetext{
${ }^{23}$ O corpus foi extraído do Projeto de Estudo da Norma Lingüística Urbana Culta de São Paulo (Projeto NURC/SP), A linguagem falada culta na cidade de São Paulo, Volume II - Diálogos entre dois informantes, Ataliba Teixeira de Castilho e Dino Preti.
} 
Nessa amostra, identifiquei um total de 159 ocorrências de orações com a estrutura para + infinitivo. Feita essa identificação, iniciei um trabalho de leitura e interpretação dos dados à luz de critérios importantes para esse tipo de estrutura, tal como propõem os vários autores resenhados na seção sobre Revisão do Tema.

Essa tarefa mais minuciosa de análise dos dados ocorreu simultaneamente a um trabalho de controle desses mesmos critérios por meio da codificação, tal como propõe a metodologia laboviana. Adiante, explicito os critérios utilizados para essa análise bem como a explicação e a exemplificação pertinente. Creio que, expondo esse encaminhamento metodológico, demonstro as inovações pelas quais tem passado a estrutura para + infinitivo no português culto.

\section{GRUPOS DE FATORES: CRITÉRIOS INVESTIGADOS}

Durante o contato com os dados, senti que precisa identificar critérios a partir dos quais eu pudesse estabelecer as nuanças funcionais que intuitivamente eu percebia na leitura dos dados.

Num primeiro momento, sem mesmo ter condições ainda de dizer se era um bom ou mau critério distintor, fui me guiando por toda e qualquer pista que se demonstrasse aplicável ao conjunto de dados.

Nesta seção, apresento o rol de critérios, no jargão sociolingüístico mais conhecido como variáveis independentes ou grupos de fatores, que orientaram o trabalho de análise dos dados até esse momento. 


\section{Quadro 2: GRUPO DE FATOR 1: SEXO}

\section{SEXO: Feminino / Masculino}

Para a empreitada de identificação dos dados investigados, foram utilizados 8 grupos de fatores, sendo o $1^{\circ}$ deles o sexo dos informantes. Assim, as ocorrências identificadas foram distribuídas entre os 12 informantes (6 homens e 6 mulheres).

\section{Quadro 3 : GRUPO DE FATOR 2: ESTRUTURA FORMAL}

$$
\begin{gathered}
\text { PARA + VERBO } \\
0+\text { VERBO } \\
\text { PARA + MATERIAL INTERVENIENTE + VERBO }
\end{gathered}
$$

Com relação ao $2^{\circ}$ grupo de fator (estrutura formal), foram selecionados 3 subfatores, os quais dizem respeito à forma como estão estruturadas as orações sob análise. Pelos dados analisados, a maioria apresenta como estrutura formal orações em para + infinitivo (para $+v)$, como nos exemplos (42) a (44):

(42) Você vê né?o mundo quer que nós conservemos a....Amazônia para controlar a poluição mundial..(INF 69)

(43) Depois eu tiro aí um...uma hora e meia...duas horas para almoçar.(INF 70)

(44) eu saio de casa normalmente...às quinze para as sete para entrar às oito no serviço.(INF 69)

Nas amostras do português de São Paulo, foram encontradas apenas 2 dados em que de concorre com para ${ }^{24}$, sendo desconsiderado esse subfator neste trabalho.

\footnotetext{
${ }^{24}$ De acordo com Gorki (2000,2001), são encontradas em Florianópolis construções em que de concorre com para.
} 
No entanto, aparecem dados, embora em uma quantidade bastante inferior, em que a preposição para é vazia, mas com valor de finalidade, como podemos notar no exemplo (45):

(45) ...Tenho saído sim...assim em termos mas eu acho por exemplo:....de sair:....éh sabe sair por aí:: (0) descobrir lugares novos e tal...(INF-441).

Dentre as orações em análise, encontramos orações em que sua estrutura formal era para $+S N+$ verbo, para + pronome + verbo e para + advérbio + verbo, os quais apresentaremos em exemplos na explicação do quadro abaixo, que trata melhor sobre a questão dos materiais intervenientes encontrados nas estruturas.

\section{Quadro 4 : GRUPO DE FATOR 3: MATERIAL INTERVENIENTE}

\begin{tabular}{|c|}
\hline PRONOME \\
SN \\
ADVÉRBIO \\
\hline
\end{tabular}

Muitas orações apresentam material interveniente entre para e verbo infinito, daí a necessidade de um controle sobre o efeito dessa intercalação. Para essa análise, foram selecionados 3 subfatores. Encontrei casos em que aparece o pronome interpolando-se, como nos exemplos (46) e (47), mas também advérbios, como nos exemplos (48) e (49):

(46) e nem ter vontade de sair de lá para me deslocar para algum outro local...(INF 69)

(47) como você utiliza seu tempo de trabalho...ele tem que ser...bem utilizado para você efetuar suas vendas...(INF 70)

(48) L1...de colocá-lo no seu lugar né?

L2 no seu lugar para não perturbar...(INF-472)

(49) mas você primeiro tem que sentir a verdade para depois atuar com ela né? (INF442) 
Também encontrei orações em que SNs aparecem interpolando-se, como podemos ver nos exemplos (50) a (53):

(50)... existem espetáculos de sexo...para o público discutir.(INF 70)

(51)... então enquanto não for...não houver esse projeto resolvido para o pessoal ter essa promoção... (INF 472)

(52)...como o TEMpo de que dispunha era Muito...inferior ao tempo necessário para o trem chegar face ao atraso... eu tive que descer no meio do caminho...(INF 303)

(53)...a programação do casal fica muito limitada assim realmente à vida das crianças... e a idade deles ainda não é uma idade de freqüentar teatro compreende? o próprio cinema para a gente tirar assim uma noite por semana é difícil...(INF 304)

\section{Quadro 5 : GRUPO DE FATOR 4: VALOR SEMÂNTICO}

\begin{tabular}{|c|}
\hline FINALIDADE \\
DESBOTAMENTO SEMÂNTICO \\
ENCAIXAMENTO \\
AMBÍGUA \\
DISCURSIVA \\
\hline
\end{tabular}

Ao buscar uma paráfrase adequada para a oração, notei que os dados não constituíam um conjunto homogêneo. Retomei, então, a tarefa, dessa vez estabelecendo um continuum semântico a partir de uma estrutura final. O valor semântico das orações para+infinitivo é o ponto-chave na identificação das rotas de gramaticalização, ou seja, a variável dependente. Durante essa análise, identifiquei 5 nuanças semânticas, as quais seriam, teoricamente, capazes de organizar os dados estudados: finalidade (exemplos 54 a 56), desbotamento semântico (exemplos 57, 58 e 59), argumento sintático encaixamento, que são orações entrelaçadas, mas com o valor semântico de finalidade, (exemplos 60, 61 e 62), ambígua (exemplos 63 a 25) que são orações que podem 
desempenhar finalidade, mas de forma duvidosa e discursiva, que são orações mais próximas da fala , portanto, perdendo seu valor de finalidade (66):

(54) você sai de manhã às vezes você sai agasalhado...na hora do almoço você precisa sair um pouquinho para ir fazer qualquer negócio seu particular...(INF 69)

(55) não vocês precisam...fazer um investimento hoje...certo? para poder colher frutos mais tarde...(INF 70)

(56) e fora uma fase toda crítica que atravessou o teatro né...?...sem subsídios...não haviam subsídios para auxiliar.(INF 70)

(57) então o tempo para mim é imprescindível que ele (seje) bom... certo? Para poder me deslocar e inclusive render muito mais no serviço. (INF 70)

(58) como você utiliza seu tempo de trabalho...ele tem que ser...bem utilizado para você efetuar suas vendas (INF 70)

(59) tem que estar ligada a um hospital para poder atender (INF 70).

(60) ... é realmente fornecer condições para ele se desenvolver (INF 70)

(61) como a empresa às vezes não tem disponibilidade financeira para...para manter um indivíduo estudando... (INF 70)

(62) as verbas hoje em dia estão mais destinadas para atender a oitenta milhões...ela é mais dirigida...para alfabetização. (INF 70)

(63) porque eu tenho crianças várias para pegar na escola...(INF-473)

(64) parece que a cidade não tem superego para para para...funcionar::ela está...cres::ce descres::ce...(INF-442)

(65)... existem espetáculos de sexo...para o público discutir.(INF 70)

(66) essas companhias de ônibus desses ônibus fumacentos né?...não há controle...os americanos já estão bem mais à frente né? Para você ver a moto aí...ela não faz barulho por quê? Tem uma linha americana que impõe setenta e cinco...decibéis... (INF-442).

Esclareço que o desbotamento semântico refere-se aos dados em que o valor de condição também é incorporado ao período; orações que acumulam tanto a função de 
argumento sintático quanto o de finalidade já enfraquecido foram classificadas como orações ambíguas; por fim, as discursivas revelam usos que, cristalizados, conformam uma modalidade voltada para o interlocutor.

\section{Quadro 6: GRUPO DE FATOR 5: POLARIDADE}

\begin{tabular}{|c|}
\hline POSITIVO + POSITIVO \\
POSITIVO + NEGATIVO \\
NEGATIVO + NEGATIVO \\
NEGATIVO + POSITIVO \\
\hline
\end{tabular}

Em se tratando de uma finalidade, espera-se que a ocorrência de polaridade negativa seja pouco produtiva, pois frustra a possibilidade de que se alcance o objetivo. Saber se as orações que deslizaram funcionalmente atendem a esse critério como meio de discernir os valores semânticos será de fundamental importância para uma descrição mais adequada da estrutura.

Dividi, então, as orações entre afirmativas (de polaridade positiva), tal como exemplificado em (67) e (68), e negativas (polaridade negativa), tal como ilustrado em (69) e (70). Não identifiquei casos em que houvesse a concordância negativa entre as orações (polaridade negativa + polaridade negativa).

(67) pena que se espere tanto né?...para tomar as medidas sérias.

(68) ...você tem que ter várias linhas para cobrir toda a área de São Paulo e distribuir né?(INF-442)

(69) L1...de colocá-lo no seu lugar né?

L2 no seu lugar para não pertubar...(INF-472)

(70) se bem que para ser procurador de Es/Geral do Estado não precisa ser da carreira né? (INF-473). 


\section{Quadro 7 : GRUPO DE FATOR 6: SEMÂNTICA DO VERBO}

\begin{tabular}{|c|}
\hline AÇÃO FÍSICA \\
AÇÃO MENTAL \\
ESTADO \\
MOVIMENTO \\
DICENDI \\
PERCEPTIVO \\
MODAL (POSSIBILIDADE) \\
CONSEGUIR \\
PROCESSO \\
\hline
\end{tabular}

Verifiquei o valor semântico do verbo que vem depois da preposição para, para que pudesse avaliar se esse aspecto poderia influenciar funcionalmente na estrutura infinitiva. Assim, encontrei os seguintes valores:

a) Ação física: "Depois eu tiro aí um...uma hora e meia...duas horas para almoçar.(INF 70)

b) Ação mental: “...você poderia pegar voltar para sua casa num cinema distrair um pouco entende?"(INF 69)

c) Estado: "como a empresa às vezes não tem disponibilidade financeira para...para manter um indivíduo estudando... (INF 70)

d) Movimento: "você sai de manhã às vezes você sai agasalhado...na hora do almoço você precisa sair um pouquinho para ir fazer qualquer negócio seu particular..."(INF 69)

e) Dicendi: "existem espetáculos de sexo...para o público discutir.”(INF 70)

f) Perceptivos: "então é aproveitar agora e a gente dá os passos certos para ver se encaixa...”(INF69)

g) Modal de possibilidade: “... então o tempo para mim é imprescindível que ele seje bom... certo? Para poder me deslocar e inclusive render muito mais no serviço...”(INF 70)

h) Conseguir: “... cidade que não dá para ter planejamento ela está crescendo desordenadamente"(INF 442)

i) Processo: “...vocês vão ao assim algum lugar para se distrair?” (INF 304) 


\title{
Quadro 8: GRUPO DE FATOR 7: PRESENÇA DO SUJEITO
}

\author{
CORREFERENCIALIDADE DE SUJEITO \\ NÃO CORREFERENCIALIDADE DE SUJEITO
}

A correferencialidade é critério importante para checar o grau de integração das orações combinadas, pois são orações em que a oração núcleo pode ou não compartilhar o mesmo sujeito com a oração para + infinitivo. Para controlar esse aspecto, verifiquei se os sujeitos detinham identidade semântica (ver exemplos 71 a 77) ou não-identidade semântica (ver exemplos 78 a 84):

(71) fui sentei com a maior boa vontade para poder entender...(INF 70).

(72)...eu saio de casa normalmente...às quinze para as sete para entrar às oito no serviço.(INF 69).

(73) não há doutores para...ministrar esses cursos... (INF 70)

(74)...mas o indivíduo para fazer um curso de três anos...ele paga...a mesma coisa que um indivíduo que vai fazer um curso de quatro ou cinco anos...(INF 70).

(75)...fui sentei com a maior boa vontade para poder entender...(INF 70).

(76) ...estudei bem fiz um estudo certinho para ver qual era a melhor...(INF-472)

(77) ...eu não tenho certeza para julgar. (INF-472).

(78)...existem espetáculos de sexo...para o público discutir.(INF 70).

(79)...é realmente fornecer condições para ele se desenvolver.(INF 70).

(80)...por exemplo poluição agora todo mundo fala poluição poluição o controle não não dá para haver controle de poluição... (INF-442).

(81)...é uma...das opções de transporte...(agora) para você...transportar a massa...(INF442). 
(82) ... nós temos uma linha... coitadinha não sei se dá para chamar ela de metrô... (INF-442).

(83) ...dá dinheiro para esse outro para ele construir a ponte mas sem outra função né?... (INF-442).

(84) ...como o TEMpo de que dispunha era Muito...inferior ao tempo necessário para o trem chegar face ao atraso...eu tive que descer no meio do caminho...(INF-303).

\section{Produtividade na língua falada: Padrões Funcionais}

Após a "codificação" ou análise de cada ocorrência, lancei mão de alguns programas do pacote varbrul a fim de organizar melhor e quantificar os dados em função das variáveis selecionadas.

Para esta etapa de análise, foi necessário determinar a variável dependente, ou seja, aquele critério que, intuitivamente, se mostrava o mais adequado para orientar a distribuição dos dados ou, ainda, aquele critério que permitisse uma observação mais clara das diferenças entre as ocorrências selecionadas. Selecionei o "valor semântico da oração subordinada" para esse fim. O resultado dessa quantificação e correlação apresento a seguir:

\begin{tabular}{|c|c|c|c|c|c|c|c|}
\hline \multicolumn{8}{|c|}{ final desbotamento Encaixamento Ambígua discursiva TOTAL } \\
\hline \multirow[t]{2}{*}{ masc. } & $\mathrm{N}$ & 69 & 35 & 9 & 7 & 3 & 123 \\
\hline & $\%$ & 56 & 28 & 7 & 6 & 2 & \\
\hline \multirow[t]{2}{*}{ Fem. } & $\mathrm{N}$ & 27 & 7 & 2 & 0 & 0 & 36 \\
\hline & $\%$ & 75 & 19 & 6 & 0 & 0 & \\
\hline \multirow[t]{2}{*}{ Total } & $\mathrm{N}$ & 96 & 42 & 11 & 7 & 3 & 159 \\
\hline & $\%$ & 60 & 26 & 7 & 4 & 2 & \\
\hline
\end{tabular}

Tabela 1: Correlação Sexo do informante X valor semântico 
De um total de 12 informantes, foram selecionados 6 homens e 6 mulheres, que usam de forma dessemelhante a estrutura sob análise. Os homens empregaram muito mais vezes (123 ocorrências) as orações com a estrutura para+infinitivo do que as mulheres (36 ocorrências).

Assim, os usos inovadores, que são as orações com desbotamento semântico e as encaixadas, as quais representam maior entrelaçamento e que estão caminhando para um processo de gramaticalização, quanto às orações prototípicas de finalidade parecem ser usos com maior frequiência entre os homens. Os homens, além de utilizarem muito mais as orações para + infinitivo prototípicas de finalidade, com um total de 69 dados, também fazem bastante uso das estruturas consideradas inovadoras, tendo um total de 54 dados, nos diversos usos novos, inclusive, das orações discursivas, que são dados com pouca recorrência, e os únicos dados que aparecem são utilizados pelos informantes do sexo masculino.

O que podemos observar, também com a tabela 1, é que as mulheres escolhidas para esta análise, além de utilizarem pouco as estruturas infinitivas antecedidas pela preposição para, correspondendo a 36 dados, fazem uso de pouquíssimas estruturas inovadoras; do total, aparecem apenas 9 dados, das quais, 7 estruturas com desbotamento semântico e apenas 2 dados de encaixamento, não aparecendo nenhum uso ambíguo ou discursivo. O que nos leva a confirmação de que as mulheres parecem estar mais preocupadas em colocar em uso estruturas prototípicas e vinculadas à normatividade $^{25}$

\footnotetext{
25 Diriam os sociolingüísticos que isso demonstra que a escolarização teria maior impacto sobre as mulheres do que sobre os homens, mas isso de fato não posso comprovar.
} 


\begin{tabular}{|c|c|c|c|c|c|c|c|}
\hline \multirow{3}{*}{ para+v } & & final & desbotamento & Encaixamento & Ambígua $c$ & discursiva & TOTAL \\
\hline & $\mathrm{N}$ & 83 & 35 & 6 & 5 & 2 & 131 \\
\hline & $\%$ & 63 & 27 & 5 & 4 & 2 & \\
\hline \multirow[t]{2}{*}{$0+v$} & $\mathrm{~N}$ & 0 & 0 & 1 & 1 & 0 & 2 \\
\hline & $\%$ & 0 & 0 & 50 & 50 & 0 & \\
\hline \multirow[t]{2}{*}{ Material $^{26}$} & $\mathrm{~N}$ & 13 & 7 & 4 & 1 & 1 & 26 \\
\hline & $\%$ & 50 & 27 & 15 & 4 & 4 & \\
\hline \multirow[t]{2}{*}{ Total } & $\mathrm{N}$ & 96 & 42 & 11 & 7 & 3 & \\
\hline & $\%$ & 60 & 26 & 7 & 4 & 2 & 159 \\
\hline
\end{tabular}

Tabela 2: Correlação estrutura formal $x$ valor semântico

A tabela 2 apresenta dados que me permitem afirmar que, de um total de 159 orações, 131 não possuíam nenhum tipo de material interveniente. Este tipo de estrutura mais recorrente representa um total de $63 \%$ no seu valor prototípico, contra $38 \%$ dos que consideramos usos inovadores (com desbotamento semântico, as encaixadas, e as ambíguas), o que, embora em menor número, nos revela uma grande quantidade de estruturas para + infinitivo nos diversos novos usos.

As estruturas com material interveniente ( $\mathrm{SNs}$, pronomes e advérbios), corresponderam a um total de 26 dados, e embora aparecessem poucos dados com material interveniente, 13 deles (50\%) corresponderam aos usos inovadores, o que é um número considerável, e que nos leva a pressupor que o material interveniente não é um fator decisivo para mudanças sintáticas e semânticas das estruturas para + infinitivo, mas pode ser um grande colaborador, como casos em que estas estruturas pendem para a discursivização, normalmente estão ligadas por um material interveniente.

\footnotetext{
${ }^{26}$ Refere-se à estrutura: para + material interveniente.
} 


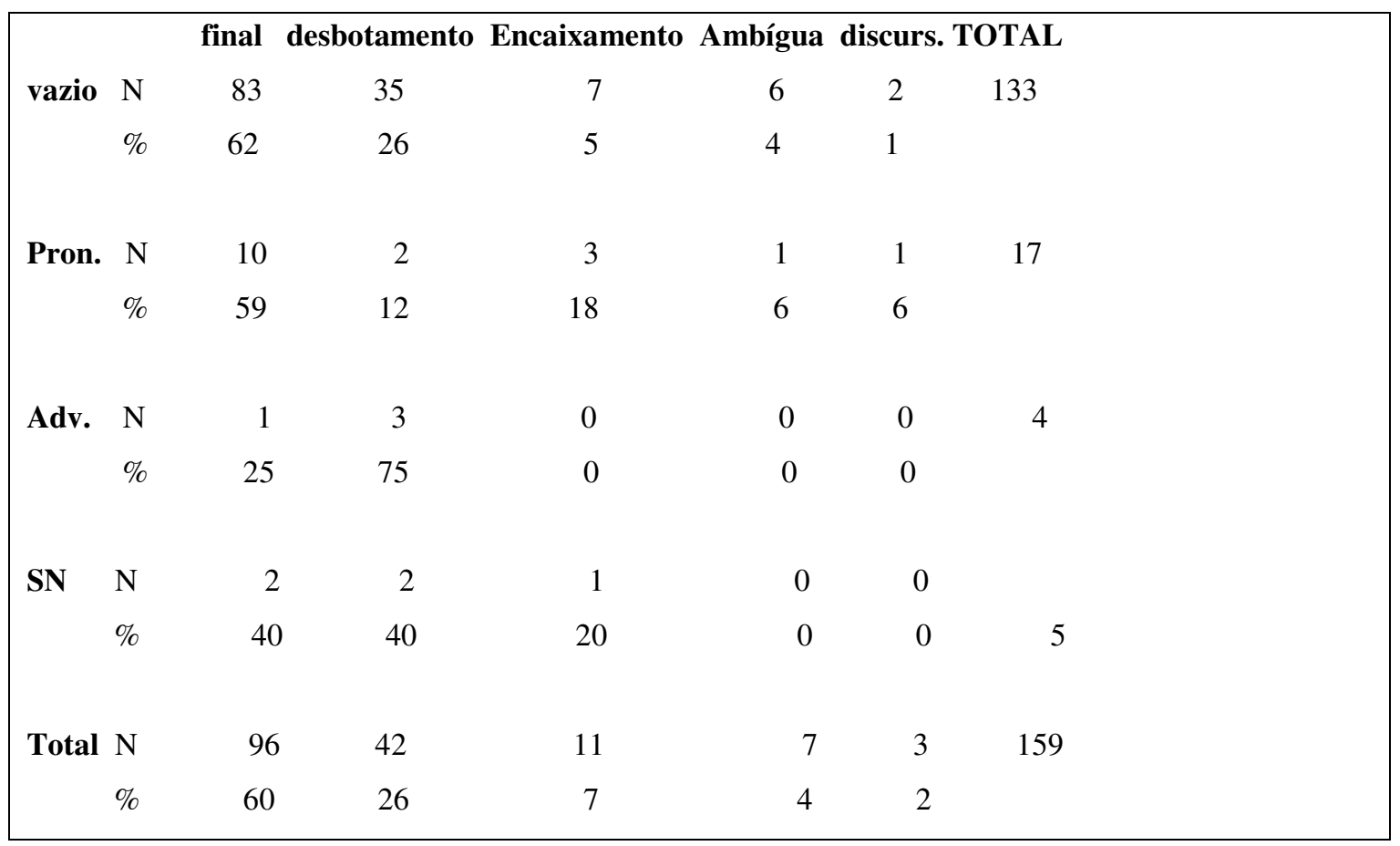

Tabela 3: Correlação material interveniente $X$ valor semântico

A tabela 3 apresenta números que representam a recorrência do tipo de material interveniente da estrutura sob análise e, como já visto na tabela 2, a maioria dessas orações não apresenta material interveniente, o que representa um total de 133 dados, sendo 83 deles (62\%) no valor de hipotáticas adverbiais. Embora em número bastante restrito, o pronome é o material interveniente mais recorrente nas estruturas analisadas, representando um total de 17 ocorrências, sendo que 10 dados (59\%) aparecem na função prototípica e 7 ocorrências (42\%) nos demais usos, principalmente com sua função semântica comprometida, enquadrando-se no que foi classificado nesta pesquisa como desbotamento semântico.

Das 4 ocorrências que apareceram com advérbio interpolando para + oração infinitiva, somente 1 era prototípica de finalidade, e das 5 ocorrências com SNs, apenas 2 o eram. Desta forma, o que podemos pressupor é que, o aparecimento de material interveniente pode ser um grande fator para o surgimento de novos valores semânticos e 
sintáticos desta estrutura, pois, embora tenham aparecido poucos dados, na sua grande maioria constituíam usos que não os prototípicos de finalidade.

Assim, junto à maioria dos exemplos em que apresento os diversos usos dessa estrutura, há os que possuem materiais intervenientes, casos em que ocorre um distanciamento do valor de finalidade, ou seja, um desbotamento semântico, como no caso da oração para + infinitivo que tem como material interveniente um pronome ou no caso em que o material interveniente é pronome, mas que ao invés de apresentar divergência no seu estatuto semântico, tem seu estatuto sintático alterado. Houve também casos em que o material interveniente é um pronome e o resultado da leitura é uma ambigüidade pragmática.

Os exemplos que ilustram a análise desenvolvida nesta dissertação nos revelam que o material interveniente também pode ser um fator desencadeador da nova leitura. Essa afirmação poderia ser melhor validada, no entanto, a partir de um trabalho diacrônico.

\begin{tabular}{|c|c|c|c|c|c|c|c|}
\hline \multirow[b]{2}{*}{ Pos+pos } & \multicolumn{2}{|r|}{ fina } & $\overline{\operatorname{tam}}$ & \multicolumn{4}{|c|}{ Encaixamento Ambígua discurs. TOTAL } \\
\hline & $\mathrm{N}$ & 87 & 24 & 10 & 5 & 0 & 126 \\
\hline & $\%$ & 69 & 19 & 8 & 4 & 0 & \\
\hline \multirow[t]{2}{*}{$\mathrm{Neg}+\mathrm{pos}$} & $\mathrm{N}$ & 7 & 15 & 1 & 1 & 0 & 24 \\
\hline & $\%$ & 29 & 63 & 4 & 4 & 0 & \\
\hline \multirow[t]{2}{*}{ Pos+neg } & $\mathrm{N}$ & 2 & 3 & 0 & 1 & 3 & 9 \\
\hline & $\%$ & 22 & 33 & 0 & 11 & 33 & \\
\hline \multirow[t]{2}{*}{ Total } & $\mathrm{N}$ & 96 & 42 & 11 & 7 & 3 & 159 \\
\hline & $\%$ & 60 & 26 & 7 & 4 & 2 & \\
\hline
\end{tabular}

Tabela 4: Correlação Polaridade X valor semântico 
A tabela 4 sintetiza a distribuição da polaridade das orações para + infinitivo e os resultados evidenciam que a grande maioria dos casos detém polaridade positiva, com um total de $69 \%$ delas, 87 dados, no seu valor prototípico, o que contrariaria nossas hipóteses iniciais se os valores semânticos se mantiverem no conjunto da finalidade.

Com a verificação dessa pendência, notei uma distribuição um pouco diluída. Os usos inovadores (desbotamento semântico, encaixada, e ambígua) responderem por $31 \%$ dos casos, ou seja 39 dados. Observei que, na combinação de polaridade negativa/positiva (24 dados), apenas 7 (29\%) estão no seu valor prototípico, o restante, ou seja, 17 dados (71\%) equivalem a usos inovadores.

Na relação inversa, ou seja, das orações com a polaridade positivo/negativo, dos 9 casos encontrados, apenas 2 estão no seu sentido prototípico. Dessa forma, percebe-se que as estruturas para + infinitivo, que possuem polaridade diferente, seja oração núcleo positiva e oração para + infinitivo negativa, ou no sentido inverso, parecem estar passando por processo de mudanças semânticas e sintáticas, tendo seu sentido esvaziado, com valor ambíguo e até mesmo apresentando maior entrelaçamento com relação à principal, na posição de encaixamento. Esse comportamento revela um processo de gramaticalização.

Assim, pelo que os dados mostram, é que, sem dúvida, o fator polaridade negativa tem uma parcela bem grande de responsabilidade com relação às mudanças que estão ocorrendo com as estruturas para + infinitivo, e pode ser um dos fatores que está levando tal estrutura a alcançar um processo de gramaticalização. 


\begin{tabular}{|c|c|c|c|c|c|c|c|}
\hline \multirow[b]{2}{*}{ movim. } & & final & desbotamento & Encaixamento & Ambígua & discurs. & TOTAL \\
\hline & & 11 & 4 & 1 & 1 & 0 & 17 \\
\hline & $\%$ & 65 & 24 & 6 & 6 & 0 & \\
\hline \multirow[t]{2}{*}{ modal } & $\mathrm{N}$ & 9 & 7 & 0 & 0 & 0 & 16 \\
\hline & $\%$ & 56 & 44 & 0 & 0 & 0 & \\
\hline \multirow[t]{2}{*}{ físico } & $\mathrm{N}$ & 35 & 13 & 5 & 4 & 0 & 57 \\
\hline & $\%$ & 61 & 23 & 9 & 7 & 0 & \\
\hline \multirow[t]{2}{*}{ mental } & $\mathrm{N}$ & 7 & 3 & 0 & 0 & 0 & 10 \\
\hline & $\%$ & 70 & 30 & 0 & 0 & 0 & \\
\hline \multirow[t]{2}{*}{ Estado } & $\mathrm{N}$ & 4 & 2 & 2 & 1 & 0 & 9 \\
\hline & $\%$ & 44 & 22 & 22 & 11 & 0 & \\
\hline \multirow[t]{2}{*}{ Percep. } & $\mathrm{N}$ & 9 & 2 & 0 & 0 & 1 & 12 \\
\hline & $\%$ & 75 & 17 & 0 & 0 & 8 & \\
\hline \multirow[t]{2}{*}{ Processo } & & 9 & 5 & 2 & 0 & 2 & 18 \\
\hline & $\%$ & 50 & 28 & 11 & 0 & 11 & \\
\hline \multirow[t]{2}{*}{ Dicendi } & $\mathrm{N}$ & 7 & 3 & 0 & 1 & 0 & 11 \\
\hline & $\%$ & 64 & 27 & 0 & 9 & 0 & \\
\hline \multirow[t]{2}{*}{ Cons. } & $\mathrm{N}$ & 5 & 3 & 1 & 0 & 0 & 9 \\
\hline & $\%$ & 56 & 33 & 11 & 0 & 0 & \\
\hline \multirow[t]{2}{*}{ Total } & $\mathrm{N}$ & 96 & 42 & 11 & 7 & 3 & 159 \\
\hline & $\%$ & 60 & 26 & 7 & 4 & 2 & \\
\hline
\end{tabular}

\section{Tabela 5: Correlação verbo complemento da preposição $X$ valor semântico}

Com relação ao tipo de verbo complemento, os resultados permitem afirmar que o maior número de ocorrências associa-se a verbos de ação física, que, no total de 159 ocorrências, correspondem a 57 dados. Nesses dados, percebi que os que se encaixam nas características das orações prototípicas de finalidade representam um equivalente a $61 \%$ dos dados, contra um total de 39\% dos demais usos (desbotamento semântico, 
encaixamento e ambigüidade interpretativa), o que é um número bastante considerável. Dentre esses usos, encontrei um total de 13 dados, $23 \%$ de orações que foram analisadas no estatuto de encaixamento, ou seja, na mudança de hipotática para subordinação, o que revela um entrelaçamento bastante acentuado e remete a um processo de gramaticalização em andamento.

No que diz respeito aos verbos modais de possibilidade, dos 16 dados encontrados, 9 eram prototípicos de finalidade e 7 apresentavam seu estatuto semântico prejudicado, sendo enquadrados no estatuto de desbotamento semântico, não apresentando nenhum outro uso inovador.

As estruturas com para + poder + verbo infinitivo parecem estar num processo de amalgamação, nas quais, embora desnecessário, o verbo "poder" torna-se uma espécie de ligação entre para + infinitivo, como se a estrutura estivesse se cristalizando entre para + infinitivo. O efeito disso é que na maioria das estruturas há um desbotamento semântico, ocorrendo uma harmonia entre a modalidade do poder e o valor de finalidade, ilustrado nos exemplos seguintes:

(85) ...então o tempo para mim é imprescindível que ele (seje) bom... certo? Para poder me deslocar e inclusive render muito mais no serviço...(INF 70)

(86) ...tem que estar ligada a um hospital para poder atender...(INF 70)

(87)...não vocês precisam...fazer um investimento hoje...certo? para poder colher frutos mais tarde...(INF 70)

(88)...e precisam ter a categoria de doutores para poder lecionar nesses cursos de pósgraduação.(INF 70)

(89)...uma parte administrativa bem precisa...(certo?) dinâmica... para poder entender...(INF 70) 
(90)...fui sentei com a maior boa vontade para poder entender...(INF 70)

(91)...almoçar depressa para dar tempo de digestão para poder entrar na escola às duas horas...

(92)...você...sabe você estar equilibrado antes:....enquanto indiVIduo para poder enxergar...(INF-441)

É possível depreender, com base nesses exemplos, que o desbotamento semântico é muito comum nesse tipo de estrutura com o verbo modal "poder", pois, embora a finalidade esteja presente, fica ofuscada pelo valor de condição, como em: "Para que eu possa me deslocar, o tempo deve estar bom". Essa é uma primeira interpretação que vem ao interlocutor, embora também seja possível interpretar da seguinte maneira: "É imprescindível que o tempo esteja bom para que eu possa me deslocar", com a finalidade presente, embora ofuscada: "o tempo estar bom para a finalidade de se deslocar".

No exemplo (86), é quase imperceptível a finalidade, pois inicialmente a idéia de condição se sobrepõe: “eu poderei atender se eu estiver ligada a um hospital”. Para que se chegue ao valor semântico de finalidade, é necessário que se interprete da seguinte maneira: “Tem que estar ligada a um hospital a fim (para a finalidade) de que eu possa atender". Assim, embora se perceba o valor de finalidade, este se mistura com o valor de condição, daí um desbotamento semântico, o que culmina com um processo de mudanças das estruturas para + infinitivo ocasionadas pelo verbo modal poder.

Isto se dá pelo fato de que o verbo poder está no campo da modalização dos enunciados e provém da natural utilização de termos relativos a noções de base lógica como possibilidade, necessidade, probabilidade, factualidade (NEVES, 2006). 
Wierzbicka $(1988)^{27}$ chama a atenção para o problema que resulta do emprego de palavras e expressões do jargão filosófico, tais como contingência, possibilidade, necessidade, factualidade na definição de palavras que também se usam corriqueiramente, como por exemplo os verbos modais (poder, dever, precisar). Para essa autora, a tentativa de esclarecimento, que consiste em traduzir palavras de noção considerada complexa por palavras mais complexas e obscuras ainda, além de arbitrária, resulta na introdução de conceitos que não são, eles próprios, esclarecidos e definidos.

Assim, o que posso perceber é que além do verbo da oração núcleo ser um dos fatores para o desbotamento das estruturas para + infinitivo, como é o caso de orações com verbos ter ou dar (dar para), o verbo modalizador "poder" também parece afetar o estatuto semântico das orações infinitivas, pois, a partir do momento em que ele se interpola entre para e verbo infinito, sugere ao interlocutor a idéia de possibilidade: "para que se possa fazer algo, é necessário....", assim acabamos apreendendo a idéia de condição: “ poderei fazer algo se...”. Esse é o caminho para que se possa analisar os exemplos acima como condicionais:

(85a) Poderei me deslocar se o tempo estiver bom.

(86a) Poderei atender se estiver ligada a um hospital.

(87a) Poderei colher frutos mais tarde se fizer um investimento.

(88a) Poderei lecionar se tiver categoria de doutor.

(89a) Poderei entender se tiver uma parte administrativa bem precisa.

(90a) Poderei entender se sentar com a maior boa vontade.

(91a) Poderei entrar na escola às duas horas se almoçar depressa.

(92a) Poderá enxergar se estiver equilibrado enquanto indivíduo.

\footnotetext{
${ }^{27}$ Apud Neves, 2006.
} 
Pelos dados colhidos e pelos resultados apresentados sobre a estrutura para poder + verbo infinitivo, percebo que esse tipo de verbo interpolado à estrutura pode também ser um dos fatores que cause desbotamento semântico nas estruturas para + infinitivo.

Ao tratar dos verbos perceptivos, obtive resultados pouco significativos para qualquer afirmação, pois dos 12 dados encontrados: 9 são orações prototípicas e 3 inovadoras. Desses inovadores, apenas 1 assume a função plenamente discursa, o que permite questionar se as orações com caráter discursivo tão pouco recorrentes neste tipo de estrutura, podem ser motivadas por verbos perceptivos? No entanto é uma pergunta que só será possível de ser respondida com uma quantidade maior de ocorrências.

Os verbos de movimento, embora representem $71 \%$ dos dados com características prototípicas, $28 \%$ estão relacionados ao encaixamento e ambigüidade interpretativa, o que permite pressupor que sejam estruturas que quando migram de sua prototipicidade, tendem a caminharem para um estatuto de maior entrelaçamento por saírem do seu estatuto de adverbiais e migrarem para um estágio de maior amalgamação que são as orações encaixadas. Os verbos de ação mental também estão representados em sua maioria pela prototipicidade das orações finais, com o correspondente a 7 dados, num total de 10 dados encontrados. Também os verbos dicendi, a despeito do número baixíssimo de dados, associaram-se à função prototípica.

O que essas diferenças entre os verbos poderia dizer acerca dos usos da finalidade no português? O que noto é que os verbos que trazem um substancial número de ocorrências prototípicas poderiam representar as ações mais concretas realizadas pelos indivíduos. Movimentar-se, pensar e dizer são ações freqüentes e mais concretas do que ações perceptivas e modais que não tem o indivíduo como origem da ação. 
Dado, contudo, que tenho poucos dados para essa inferência, fica aqui somente uma intuição registrada.

E o que dizer de verbos de estado, que sinalizam um evento particular e delimitado no tempo? Embora eu tenha somente 9 dados, 5 deles fazem parte dos usos inovadores, o que representa 55\%. Parece que minha intuição ainda se sustenta com base nesse resultado também.

\begin{tabular}{|c|c|c|c|c|c|c|c|}
\hline \multirow{2}{*}{\multicolumn{2}{|c|}{ Suj.cor. N }} & \multicolumn{6}{|c|}{ final desbotamento Encaixamento Ambígua discurs. TOTAL } \\
\hline & & 60 & 18 & 4 & 3 & 2 & 87 \\
\hline & $\%$ & 69 & 21 & 5 & 3 & 2 & \\
\hline Suj.não & $\mathrm{N}$ & 36 & 24 & 7 & 4 & 1 & 72 \\
\hline Corref & $\%$ & 50 & 33 & 10 & 6 & 1 & \\
\hline \multirow[t]{2}{*}{ Total } & $\mathrm{N}$ & 96 & 42 & 11 & 7 & 3 & 159 \\
\hline & $\%$ & 60 & 26 & 7 & 4 & 2 & \\
\hline
\end{tabular}

\section{Tabela 6: Correlação Característica do sujeito X Valor semântico}

Lehmann (1988) ${ }^{28}$ aponta um caso especial de integração, além da concordância sintática entre as orações: é a correferencialidade entre os sujeitos. Tendo em vista a importância desse critério em vários dos trabalhos lidos, chequei também esse critério no português paulista.

Os 159 dados analisados foram distribuídos, conforme a tabela anterior, apontam que: 87 dados apresentavam sujeitos correferenciais e 72 sujeitos não-correferenciais; 60 dados $(69 \%)$ com os sujeitos correferenciais apresentaram-se na função prototípica de finalidade, contra um total de 27 dados $(31 \%)$ de orações com os demais usos, sendo 18 desses dados, ou seja, a maioria desses usos, fazem parte de estruturas com desbotamento semântico.

\footnotetext{
${ }^{28}$ Apud Gorski e Neves 2004
} 
Assim, posso afirmar que, de fato, as orações para + infinitivo que partilham o mesmo sujeito normalmente mantém seu estatuto prototípico de finalidade, ao contrário das orações que não partilham o mesmo sujeito, que têm a tendência à alteração de seus estatutos tanto sintáticos quanto semânticos.

Um dado de muita importância é que, com relação às orações com o sujeito nãocorreferencial, dos 72 dados encontrados, 36 ocorrências (50\%) eram orações com usos inovadores, sendo que, desses usos, 24 dados eram estruturas com seu valor semântico afetado, enquadrando-se no caso de desbotamento.

Dessa forma, é possível perceber que a não-correferencialidade entre os sujeitos é, de fato, um fator de muita importância para esse processo que envolve não só mudanças sintáticas, mas também mudanças semânticas das estruturas finais em para + infinitivo. Este fato também já foi observado em Silva $(2005)^{29}$ ao tratar de orações para

+ infinitivo no Espanhol, evidenciando a necessidade da correferencialidade de sujeito para que essas estruturas possam ser classificadas como finais.

\section{CONJUNTOS DE DADOS DIVERGENTES}

De acordo com os dados analisados, noto que as estruturas para + infinitivo estão passando por um processo de mudança bastante interessante que pode ser associado a um estágio acentuado de gramaticalização. As mudanças são tão evidentes que alguns dados apresentam-se com um grau de divergência tão grande que a análise dessas estruturas torna-se quase que impossível, dada a imprecisão alcançada nos exercícios interpretativos a que os submeti.

\footnotetext{
${ }^{29}$ Cf Silva (2005), página 66.
} 
No momento em que os dados foram analisados, percebi que algumas estruturas se apresentaram de forma bastante divergente. Fica assim evidenciado que, à medida que a dificuldade interpretativa cresce, com sentido mais opaco, alguma mudança está em curso. Quais serão as motivações reais para tantas dificuldades interpretativas?

Durante o processo de análise, verifiquei que algumas estruturas para+infinitivo apresentam-se em duplicidade no mesmo contexto, o que dificultaria a localização da oração núcleo:

(93) L2- eu saio de casa normalmente...às quinze para as sete para entrar às oito no serviço.(INF 69)

L1- para sua residência...para voltar...(INF 70)

No exemplo (93), são duas estruturas em que uma completa o sentido da outra, formando duplas estruturas interligadas, no entanto com sua interpretação bastante divergente: "ele sai quinze para as sete para entrar às oito no serviço, para depois voltar para sua residência".

Assim, uma segunda oração para + infinitivo "para voltar" que está totalmente entrelaçada com a primeira oração "eu saio de casa normalmente...às quinze para as sete", mas também com toda a estrutura, provoca uma confusão de análise.

Lima (2004), a que já me referi anteriormente, aborda a questão de casos em que as estruturas para + infinitivo ocorrem de maneira independente, ou seja, sem vínculo explícito com uma 'principal', no entanto, produzidas por diferentes locutores ${ }^{30}$. E nesses casos, embora a estrutura seja produzida pelo mesmo locutor, pode-se com

\footnotetext{
${ }^{30}$ Capítulo 2.3: Estrutura para + infinitivo: Pesquisas lingüísticas, Lima (2004).
} 
tranqüilidade relacioná-las aos critérios de integração sugeridos por Lehmann ${ }^{31}$ quanto ao vínculo não só com uma oração núcleo, mas com todo o contexto interacional.

Há também casos em que no momento do ato discursivo, a correção, pode modificar a estrutura para + infinitivo, como no exemplo seguinte:

(94) aí você vê acho que...nós já poderíamos partir...para um...criar fonte de pesquisas aqui entende? não...ter que buscar lá fora entende? (INF 69)

No exemplo (94), tem-se uma estrutura em que o material interveniente pode ser uma correção de fala, e partir para no sentido de tomar a decisão, portanto podendo ter a seguinte interpretação: "Acho que nós poderíamos tomar a decisão de criar fonte de pesquisas aqui". No entanto, temos uma oração núcleo "acho", porém, a encaixada "que nós já poderíamos partir" necessita da infinitiva "para criar fonte de pesquisas" para que seu sentido seja completo. Desse modo, tem-se uma divergência que permite um questionamento: a oração infinitiva é o complemento da oração encaixada ou a oração encaixada + a oração infinitiva são complementos da oração núcleo?

De qualquer forma, o que ocorre de fato é um processo de intensa amalgamação de estruturas que não permitem uma leitura isolada. Não se pode negar que estão sem dúvida em processo de gramaticalização, pois são fortemente entrelaçadas e esse comportamento provoca a perda de seus valores prototípicos e ganho de outras funções tanto sintáticas quanto semânticas.

Algumas orações infinitivas se encontram em duplicidade, o que dificulta a compreensão e o reconhecimento de sua oração núcleo, uma vez que elas estão

\footnotetext{
${ }^{31}$ Apud Lima 2004.
} 
interligadas em "double bind" 32 , ora sendo finalidade da oração-núcleo, ora da infinitiva que a antecede, como ilustram os exemplos (95), (96) e (97):

(95) "almoçar depressa para dar tempo de digestão para poder entrar na escola às duas horas... (INF-472).“Almoçar depressa para dar tempo de digestão" ou "Almoçar depressa para poder entrar na escola às duas horas" ou ainda "Dar tempo de digestão para poder entrar na escola às duas”. Temos aí uma divergência: Qual será a oração núcleo?

A depender da interpretação, a oração núcleo poderá ser:

(95a) oração núcleo "Almoçar depressa" e oração final "para poder entrar na escola às duas horas".

(95b) oração núcleo "Dar tempo de digestão" e oração final "para poder entrar na escola às duas horas".

De qualquer forma, o que noto é que a oração núcleo não é a mesma para todas as construções, o que a torna polissêmica, pois mesmo feita esta avaliação não é possível decidir.

(96) um só sabe falar de outro... quando é para falar coisa errada...para contar defeito... (INF-472).

"Um só fala do outro para falar coisa errada" ou "Um só sabe falar do outro para contar defeito". Além da dupla estrutura, temos também como divergência um conectivo temporal, o que provavelmente pode estar afetando o valor semântico e sintático da infinitiva.

Neste caso, revela-se o mesmo problema de polissemia, pois as estruturas para + infinitivo partilham a mesma oração núcleo, o que as torna intensamente interligadas não só com uma estrutura núcleo, mas com todo o contexto que as cerca.

\footnotetext{
${ }^{32}$ Para aprofundar os conhecimentos sobre as estruturas double-bind, ou reduplicação sugiro o trabalho de Defendi (2008).
} 
(97) então enquanto não for...não houver esse projeto resolvido para o pessoal ter essa promoção para poder ser aberto mais rápido...(INF-472).

"Enquanto não houver esse projeto resolvido para o pessoal ter essa promoção" ou "Enquanto não houver esse projeto para poder ser aberto mais rápido" ou ainda "Ter essa promoção para poder ser aberto mais rápido". Percebo desse modo a dificuldade em localizar a oração núcleo. Assim fica a pergunta: Qual é a oração núcleo de cada infinitiva? Será que ambas possuem o mesmo valor semântico?

O que posso afirmar é que, da mesma forma dos exemplos acima, ocorre uma interligação das orações para + infinitivo com toda a estrutura, o que a torna uma construção polissêmica, com a necessidade da interação de toda a estrutura para uma possível compreensão de toda a informação.

À cada interpretação ocorreria um desbotamento semântico da estrutura, deslizando semanticamente de finalidade para valores modais de possibilidade, como já relatei em análise anterior nesta dissertação ${ }^{33}$.

Nos exemplos (98) e (99), vê-se que, muitas vezes, a comunicação espontânea pode fazer com que a estrutura seja mais difícil de ser compreendida, e com uma estrutura cada vez mais entrelaçada e ambígua:

(98) L1-de jeito nenhum e quando eles são pequenos mais

L2- ahn

L1-dificuldades a gente tem para pessoal...para servir né?

L2-certo...

L1-agora...já é mais fácil...mas quando são pequeninos( )(INF473).

(99) existem espetáculos de sexo...para o público discutir.(INF 70)

\footnotetext{
${ }^{33}$ Capítulo 3.3: Produtividade na língua falada: Padrões funcionais.
} 
Esses exemplos, como no exemplo mostrado no livro de Ernani Terra e José de Nicola, já visto anteriormente na seção sobre os livros didáticos ${ }^{34}$, também revelam um caráter bastante ambíguo com as seguintes possibilidades: "Quando eles são pequenos, mais dificuldades a gente tem para servir".

No entanto, se pudesse ocorrer a inversão da estrutura, ficaria mais evidente a ambigüidade e o distanciamento do valor de finalidade: "Para servir a gente tem dificuldade", configurando seu desbotamento semântico. No entanto, é uma estrutura na qual a posição selecionada das cláusulas é decisiva no tecer textual, e é muito rara sua inversão "para servir dificuldades a gente tem para pessoal", o que nos remete novamente ao entrelaçamento da estrutura, configurando-se assim, um processo de gramaticalização em andamento.

O mesmo ocorre com o exemplo (99), o qual de início permite até depreender um valor de finalidade, porém, com sua inversão, uma ambigüidade interpretativa se mostra: "Para o público discutir existem espetáculos de sexo", nesse rol, se depreende uma enorme problemática, pois será que os espetáculos de sexo têm a finalidade de discussão? Ou a discussão é apenas uma conseqüência do evento "espetáculo de sexo"?

A resposta é bem clara, pois todos sabem que ninguém vai a um espetáculo de sexo com a finalidade de discutir alguma questão, mas sim para se divertir, para seu deleite; esse dado inferencial impede que a finalidade seja validada como informação possível, embora se encaixe nos moldes que as gramáticas normativas pregam.

O grau de dificuldade em compreender os valores semânticos que apresentam certas estruturas infinitivas, devido a estas ambigüidades interpretativas, não é um

${ }^{34}$ O exemplo fornecido pelos autores foi: (5) Os lavradores esperavam a chuva a fim de que não perdessem a colheita. Estrutura que também depreende uma ambigüidade interpretativa. 
problema puramente científico de lingüistas funcionalistas, não. Há uma grande implicação pedagógica. Será que professores têm consciência desse problema? Será que escolares conseguem perceber essas ambigüidades nas orações infinitivas e nas que são apresentadas como finais pelos autores dos livros didáticos e essa seria uma dificuldade de aprendizagem? Essa questão será respondida adiante, no Capítulo V, em que explano os resultados da aplicação de testes para verificar se, de fato, alunos e professores conseguem perceber tais ambigüidades.

Outro problema que gera um processo de gramaticalização das orações para + infinitivo são estruturas em dar para, as quais permitem o seguinte questionamento: quais os motivos que levaram essa estrutura a cristalizar-se? Seu aparecimento no português será um efeito de apagamentos sintagmáticos entre dar e para, como é o caso do exemplo (105)? Quais os motivos que causam desbotamento semântico de tais estruturas? A polaridade negativa também se associa a essa estrutura? Para dar conta dessas questões, selecionei dados com divergências:

(100) o que não dá pra fazer durante o dia eu faço à noite. (INF-472)

(101) cidade que não dá para ter planejamento ela está crescendo desordenadamente (INF- 442)

(102) por exemplo poluição agora todo mundo fala poluição poluição o controle não não dá para haver controle de poluição... (INF-442)

(103) não::não tem muito ressonância para mim...inclusive:::é porque senão seria o seguinte a cidade pequena não tem esses problemas..não é::?não dá para fazer analogia criança adulto(INF 442).

(104) nós temos uma linha...coitadinha não sei se dá para chamar ela de metrô...(INF442).

(105)...você não quer dar uma olhada para ver se está gravando?. (INF-441) 
(106) muda a lei de zoneamento... eu não vejo funcionar... e mesmo assim seria uma restrição de... desenvolvimento... errado mas já está um montão de coisa errada certo?...muito bairro::....residencial com muita indústria dentro...principalmente bairro pobre né?...para consertar isso:::não dá...(INF-442)

No exemplo (106), percebe-se que a estrutura dar para, embora invertida, ainda continua arraigada: "Não dá para consertar isso", e a polaridade negativa também faz parte da estrutura, como nas anteriores, o que é um fator para tal desbotamento semântico das estruturas para + infinitivo, como já apresentei na seção em que trato dos critérios ou grupos de fatores investigados ${ }^{35}$.

Nos exemplos acima listados, o verbo da oração matriz dar, já demonstrado em trabalhos de outros autores ${ }^{36}$, é um dos grandes fatores para o desbotamento semântico das estruturas para + infinitivo, pois além de normalmente estar junto de uma negativa, o que é um fator de forte contribuição para as mudanças semânticas ou sintáticas dessas estruturas, é também um verbo que possivelmente passou por um processo de apagamentos, o que causa sua cristalização junto de para + infinitivo. Essas alterações teriam produzido modificações em seu estatuto prototípico de finalidade, permitindo outras leituras e inclusive causando ambigüidades pragmáticas, o que confirmaria um processo de gramaticalização em andamento.

A estrutura estar para parece estar passando pelo mesmo processo de cristalização e, da mesma forma, parece ter seu sentido prototípico de finalidade também esvaziado. Esse tipo de construção possivelmente está também passando por apagamento de SNs entre estar e para. Selecionei para essa discussão os exemplos (107) a (112):

\footnotetext{
${ }^{35}$ Capítulo 3: Produtividade na língua falada: Padrões funcionais. Tabela 4: Polaridade.

${ }^{36}$ Encontramos essas idéias nos trabalhos de Gorski (2000, 2001 e 2003) e de Menezes (2004).
} 
(107) então ele está encantado até...estou para trazê-lo aqui no museu (INF-473) .

(108)...ou existe isso ou digamos um dia de chuva está um dia horrível para trabalhar...(INF 69).

(109) ...tem que estar ligada a um hospital para poder atender...(INF 70).

(110) as verbas hoje em dia estão mais destinadas para atender a oitenta milhões...ela é mais dirigida...para alfabetização.(INF 70).

(111)... parece que está saindo de uma...condição de subdesenvolvimento para chegar sei lá numa de desenvolvido...okay?...(INF-442).

(112)...você....sabe você estar equilibrado antes:.....enquanto indiVIduo para poder enxergar...(INF-441).

O que depreendo desses exemplos é que o verbo estar na oração matriz faz com que o valor semântico da oração para + infinitivo fique enfraquecido ${ }^{37}$, tornando-se cada vez mais entrelaçada com toda a estrutura e fazendo com que passe do estatuto de adverbiais, que são mais soltas e menos gramaticalizadas, para o estatuto de encaixamento, que são muito mais entrelaçadas e também mais gramaticalizadas.

Embora exista material interveniente entre a oração matriz e a oração para + infinitivo, o que ocorre é que a oração infinitiva não mais desempenha a função de satélite, mas sim de complemento da oração matriz, o que caracteriza um grau de entrelaçamento entre ambas orações.

\footnotetext{
${ }^{37}$ Esse tema já foi alvo de discussão em Gorski, Mittmann e Neves (2003).
} 


\title{
CAPÍTULO IV
}

\section{TRANSMISSÃO E INCORPORAÇÃO DA NORMATIVIDADE AMOSTRAS DE LÍNGUA ESCRITA}

\begin{abstract}
Neste capítulo, apresento informações sobre as amostras que constituem o corpus de língua escrita desta pesquisa. Para esta tarefa, foram selecionadas redações de vestibulares da FUVEST referentes aos anos de 1999, 2001, 2002 e 2006. Assim, será apresentada a descrição dos padrões funcionais da estrutura para + infinitivo, o que consolidará posteriormente a análise quantitativa desses mesmos padrões. A escolha desse tipo de amostra se deveu à busca de respostas os empregos na língua escrita elaborada sob pressão da normatividade.
\end{abstract}

\section{LÍNGUA ESCRITA: CONSTITUIÇÃO DO CORPUS}

Com a finalidade de tornar este trabalho o mais completo possível, senti a necessidade de verificar se esses usos diferenciados das estruturas para + infinitivo também apareceriam na língua escrita.

Para essa tarefa, selecionei redações dos concursos vestibulares para ingresso na Universidade de São Paulo, já na segunda fase de seleção, referente aos anos de 1999, 2001, 2002 e 2006. Dessa forma, seria possível a realização de um estudo sobre a incorporação de usos inovadores e sobre o peso da normatividade vinda de conhecimentos adquiridos no ensino formal dos estudos colegiais.

De forma aleatória, foram escolhidas 134 redações, e desse conjunto de provas identifiquei 70 orações com a estrutura para + infinitivo, como podemos observar no quadro abaixo: 
Quadro 9: AMOSTRA DE REDAÇÕES VESTIBULARES - FUVEST

\begin{tabular}{|l|l|l|}
\hline Redações de 1999 & 50 redações & 37 orações para+infinitivo \\
\hline Redações de 2001 & 20 redações & 20 orações para+infinitivo \\
\hline Redações de 2002 & 39 redações & 5 orações para+infinitivo \\
\hline Redações de 2006 & 15 redações & 8 orações para+infinitivo \\
\hline Total & 134 redações & 70 orações para+infinitivo \\
\hline
\end{tabular}

Como podemos observar, das 50 redações referentes ao ano de 1999, encontramos 37 orações para + infinitivo. Com relação ao ano de 2001, foram selecionadas 30 redações e apareceram 20 orações dessa estrutura. Já as redações referentes ao ano de 2002, num total de 39 redações, apareceram apenas 5 orações para + infinitivo, e das 15 redações selecionadas do ano de 2006, apresentaram apenas 8 orações com a estrutura em estudo.

A justificativa para a escolha desse tipo de amostra de língua escrita deve-se ao fato de que a Fuvest é um dos mais concorridos vestibulares e, também, porque a prova de redação integra a segunda fase de seleção, após, portanto, uma grande seleção ditada pelo conhecimento geral em forma de teste.

Nesse contexto de produção, há uma pressão muito grande para que o aluno demonstre seu conhecimento da norma culta. E isso pode ajudar a reconhecer usos inovadores que não são percebidos pelo próprio aluno e até mesmo pela escola durante a preparação desses estudantes. 


\section{GRUPOS DE FATORES: CRITÉRIOS INVESTIGADOS}

Nesta seção, assim como no capítulo em que foram analisados os dados de língua falada ${ }^{38}$ apresento os grupos de fatores, que orientaram o trabalho de análise dos dados de língua escrita.

\section{Quadro 10: GRUPO DE FATOR 1: ESTRUTURA FORMAL}

\begin{tabular}{c} 
PARA + VERBO \\
$0+$ VERBO \\
PARA + MATERIAL INTERVENIENTE + VERBO \\
\hline
\end{tabular}

Para a empreitada de identificação dos dados investigados, foram utilizados 6 grupos de fatores, sendo o $1^{\circ}$ grupo de fator a estrutura formal. Tanto quanto na análise da língua falada, também foram selecionados 3 subfatores, os quais nos mostrarão como estão estruturadas as orações em estudo. Assim como já era de se esperar, a maioria dos dados nos mostram como estrutura formal orações em para + infinitivo (para $+v)$, como nos exemplos 1 a 3 :

(1)Num passado não tão distante, a juventude "Anos 60" saiu às ruas para lutar contra a ditadura.(rd500644)

(2)Nunca antes uma geração teve acesso tão rápido á informação em geral, ou liberdade para discutir ou questionar quaisquer temas.(rd500994)

(3) "Geração perdida" Esse é o nome que vem surgindo (desde) os mais diversos apelidos para caracterizar os jovens deste final de milênio.(rd501355)

\section{Quadro 11: GRUPO DE FATOR 2: MATERIAL INTERVENIENTE}

\begin{tabular}{|c|}
\hline PRONOME \\
ADVÉRBIO \\
ORAÇÃO \\
\hline
\end{tabular}

\footnotetext{
${ }^{38}$ Capítulo 3: Grupo de fatores:Critérios investigados.
} 
Para essa análise, foram selecionados 3 subfatores. Embora tenha encontrado um número bastante reduzido de estruturas com material interveniente, apareceram casos em que aparece o pronome interpolando-se, como nos exemplos 4 e 5, mas também advérbios, como nos exemplos 6 e 7 e apenas um dado em que uma oração interpola para e verbo como podemos ver no exemplo 8:

(4)e essa descategorização de sua auto-identidade se extende ao ponto do próprio jovem dispender-se da gíria- jargão tão amplamente utilizado para projetar sua auto-afirmaçãopara se ater a palavras estrangeiras.(rd501453)

(5)Não existe uma ideologia para se adotar, assim como não há uma "raça pura".(red_fuvest2001-511077)

(6)A juventude, então, sentindo-se profundamente usada, desrespeitada, e acima de tudo insolente, não vê outra solução senão refugiar-se nos efeitos paliativos do consumismo desenfreado da alienação política - para não ser cobrada.(rd514565)

(7)Assim como Machado de Assis constatou: "O menino é o pai do homem”. Essa frase destaca a importância do passado para melhor compreender a realidade atual.(red_fuvest2001-511077)

(8)Com relação a estes fatos lamentáveis, fica a esperança que a parcela destes jovens que ingressar na faculdade adquira aí consciência e determinação para, ao se formar, mudar este quadro, levando aos futuros jovens a consciência e o estímulo para agirem.(rd523089)

\section{Quadro 12: GRUPO DE FATOR 3: VALOR SEMÂNTICO}

\begin{tabular}{|c|}
\hline FINALIDADE \\
DESBOTAMENTO SEMÂNTICO \\
ENCAIXAMENTO \\
AMBÍGUA \\
DISCURSIVA \\
\hline
\end{tabular}


Durante essa análise, tanto quanto nas amostras de língua falada, foram identificadas também 5 nuanças semânticas, as quais seriam, teoricamente, capazes de organizar os dados estudados: finalidade (exemplos 9 e 10), desbotamento semântico, que são orações em que podemos ter finalidade, mas com outros valores incorporados, como o de condição, (exemplos 11, 12 e 13), argumento sintático - encaixamento (exemplos 14, 15 e 16), ambígua (exemplos 17 e 18) e discursiva (19):

(9) é nesses movimentos que se engajam hoje, os jovens que não perderam a capacidade de sonhar com um mundo melhor, lutam para melhorar a vida de uma minoria discriminada e conseqüentemente tornar mais justa a sociedade.(rd506056)

(10) Hoje, o punho de ferro da ditadura não mais pesa sobre o país. Há liberdade de pensamento e expressão (teoricamente). Votamos para eleger os governantes.(rd511689)

(11) É uma geração cética com respeito à política, ceticismo que herdou da existência de seus pais perseguidos nos anos sessenta e frustados na redemocratização dos anos oitenta e noventa. Não é uma geração sem consciência: longe disso, é antes uma geração indiferente. Uma geração que pouco espera do mercado de trabalho (mercado: palavra que agora começa a esfumaçar-se, de tanto ser usada), que receberá de braços fechados e lhe dará as costas. E que também já sabe que terá, cada vez mais, de conhecer para sobreviver, pois a vida é dura.(rd506628)

(12) Portanto, vemos que os jovens da atualidade ainda são imaturos para desempenhar várias funções que lhe cabem.(rd519786)

(13) $\mathrm{Ou}$ seja, basta ser brasileiro, para ser inferior, para não ser da raça pura.(red_fuvest2001-508950)

(14)Brasileiros sob semelhante alcunha, convivem......almeja encontrar condições para ingressar modestamente no mercado da esquina.(rd501453)

(15) O jovem percebe que existe uma grave contradição entre o que a sociedade lhe diz para ser e o que ela é.(rd514565) 
(16)Logo, percebe-se a necessidade de intervenção dos líderes mundiais na sociedade, fazendo o possível para controlar problemas como o desemprego...(red_fuvest2001509181)

(17) E a impressão que se esboça é que essa geração não tem pelo que lutar, mas apenas objetivos individuais para conquistar.(confirmar).(rd513627)

(18) É difícil precisar se um dia seremos civilizados o bastante para aceitar o "outro", o diferente. (confirmar) (red_fuvest2001-511450)

(19)No passado, nossos pais, foram, de certa forma, forçados a lutar contra essa dominação, pois viviam um momento de repressão das liberdades individuais, na época da ditadura, para ilustrar exemplo, eles amadureceram rapidamente, e os jovens de hoje, vivem um período sem grandes revoluções, em que a tendência é a individualização.(rd507920)

\section{Quadro 13: GRUPO DE FATOR 4: POLARIDADE}

\begin{tabular}{|c|}
\hline POSITIVO + POSITIVO \\
POSITIVO + NEGATIVO \\
NEGATIVO + NEGATIVO \\
NEGATIVO + POSITIVO \\
\hline
\end{tabular}

Foram encontradas orações em que a polaridade era positiva tanto na oração matriz quanto na oração para + infinitivo, como nos mostram os exemplos 20 e 21 . Apareceram também orações de polaridade diferente, sendo oração matriz positiva e oração para + infinitivo negativa, tal como ilustrado em 22 e 23, e orações onde a oração matriz era negativa e oração para + infinitivo positiva, como nos exemplos 24 e 25. Também, como na análise de língua falada, não foram identificados casos em que houvesse a concordância negativa entre as orações (polaridade negativa + polaridade negativa).

(20) Os pais precisam lutar, sem medir esforços, para transmitir aos seus filhos com mais intensidade os significados de palavras como: respeito, solidariedade e humanidade. $(\operatorname{rd} 500989)$ 
(21)...os artistas conseguem utilizar sua capacidade de criação para realizar trabalhos artísticos magníficos.(rd517416)

(22)Dessa forma, podemos concluir que os jovens dessa geração precisam de bastante orientação para não tornar maléfico um instrumento que é o maior bem que o indivíduo pode possuir: o conhecimento.(rd507455)

(23)A juventude, então, sentindo-se profundamente usada, desrespeitada, e acima de tudo insolente, não vê outra solução senão refugiar-se nos efeitos paliativos do consumismo desenfreado da alienação política - para não ser cobrada - e da cultura descartável e sem compromisso.(rd514565)

(24)Nunca antes uma geração teve acesso tão rápido á informação em geral, ou liberdade para discutir ou questionar quaisquer temas.(rd500994)

(25)Isso não quer dizer, de maneira alguma, que os adolescentes de hoje não tenham motivos para repudiar o coronelismo político que subsiste há 500 anos.(rd503129)

\section{Quadro 14: GRUPO DE FATOR 5: SEMÂNTICA DO VERBO}

\begin{tabular}{|c|}
\hline AÇÃO FÍSICA \\
AÇÃO MENTAL \\
ESTADO \\
DICENDI \\
PERCEPTIVO \\
MODAL (POSSIBILIDADE) \\
CONSEGUIR \\
PROCESSO \\
\hline
\end{tabular}

Foram encontrados os seguintes valores semânticos do verbo que vem depois de para:

1. Ação física: "Ora, se uma empresa contrata um árabe ou um judeu (vamos manter a verossimilhança) para trabalhar na Alemanha, o alemão sente-se como se este imigrante estivesse violando seu país, tomando seu emprego e seu dinheiro..." (red_fuvest2001-508045). 
2. Ação mental: “A geração de 68 viveu numa época em que o mercado de trabalho não era tão competitivo, pelo menos no Brasil, sobrando tempo para pensar em outras questões" (rd523089).

3. Estado: "Trata-se de um país heterogêneo e não há fundamento para existir preconceito" (red_fuvest2001-508045).

4. Dicendi: "Antes que o leitor mais impaciente decida criticar a juventude de hoje, porém, é necessário entender que julga-lo do ponto de vista dos anos 60 seria um ato precipitado, para não dizer injusto" (rd523643).

5. Perceptivos: "Quem deixará para trás uma oportunidade de ouro, estudos, profissão, carreira, fama e dinheiro para olhar através dos vidros térmicos do carro conversível a criança que chora e mendinga por dez centavos." (rd513217).

6. Modal de possibilidade: "Quer que ele seja bondoso e submisso ao sistema, para poder manipulá-lo mais facilmente." (rd514565).

7. Conseguir: "E a impressão que se esboça é que essa geração não tem pelo que lutar, mas apenas objetivos individuais para conquistar." (rd513627).

8. Processo: "Começava uma manifestação pró impeachment, liderada pelos chamados "cara-pintadas": jovens contribuindo para fortalecer a democracia brasileira." (rd504935).

\section{Quadro 15: GRUPO DE FATOR 6: PRESENÇA DO SUJEITO}

$$
\begin{aligned}
& \text { CORREFERENCIALIDADE DE SUJEITO } \\
& \text { NÃO CORREFERENCIALIDADE DE SUJEITO }
\end{aligned}
$$

Como já tenho apresentado neste trabalho, a correferencialidade é critério importante para checar o grau de integração das orações combinadas. Para controlar esse fator, verifiquei se os sujeitos detinham identidade semântica, ou seja, 
correferencialidade de sujeitos, conforme exemplos 26 a 29 ou não identidade semântica, não correferencialidade de sujeitos conforme exemplos 30 a 34:

(26)Num passado não tão distante, a juventude "Anos 60" saiu às ruas para lutar contra a ditadura. (rd500644)

(27)Nunca antes uma geração teve acesso tão rápido á informação em geral, ou liberdade para discutir ou questionar quaisquer temas. (rd500994)

(28)O Brasil precisa mudar em diversos aspectos para superar as suas dificuldades e os seus desafios intensamente ligadas a essa juventude. (rd506628)

(29)Brasileiros sob semelhante alcunha, convivem.......almeja encontrar condições para ingressar modestamente no mercado da esquina.(rd501453)

(30)“Geração perdida" Esse é o nome que vem surgindo (desde) os mais diversos apelidos para caracterizar os jovens deste final de milênio.(rd501355)

(31)A notícia instantânea não pode ser filtrada e adaptada para induzir politicamente o informado com facilidade (rd505827)

(32)É nesses movimentos que se engajam hoje, os jovens que não perderam a capacidade de sonhar com um mundo melhor, lutam para melhorar a vida de uma minoria discriminada e conseqüentemente tornar mais justa a sociedade. (rd506056)

(33)Para promover as grandes transformações de que o Brasil precisa, é necessário plantar sementes de valores mais duradouros, de coletividade e solidariedade. $(\operatorname{rd} 507407)$

(34)Dessa forma, podemos concluir que os jovens dessa geração precisam de bastante orientação para não tornar maléfico um instrumento que é o maior bem que o indivíduo pode possuir: o conhecimento. (rd507455).

O que é demonstrado até o momento, é que tanto na língua falada quanto na língua escrita, as estruturas para + infinitivo estão caminhando para um processo cada vez mais intenso de mudanças, pois, como temos visto nos dados apresentados acima, 
os usos inovadores não fazem parte somente da fala, mas também da escrita, assim as mudanças aparecem mesmo em casos em que o uso da normatividade é cobrado.

\section{Produtividade na língua escrita: PAdRões funcionais}

Após a "codificação" ou análise de cada ocorrência, lancei mão de alguns programas do pacote varbrul a fim de organizar melhor e quantificar os dados em função das variáveis selecionadas.

Assim como na análise das ocorrências de língua falada, foi necessário determinar a variável dependente, ou seja, aquele critério que, intuitivamente, se mostrava o mais adequado para orientar a distribuição dos dados, então foi selecionado também o "valor semântico da oração subordinada" para essa tarefa. O resultado dessa quantificação e correlação será apresentado a seguir, para que, dessa forma, possa confrontar com os resultados obtidos na análise da língua falada.

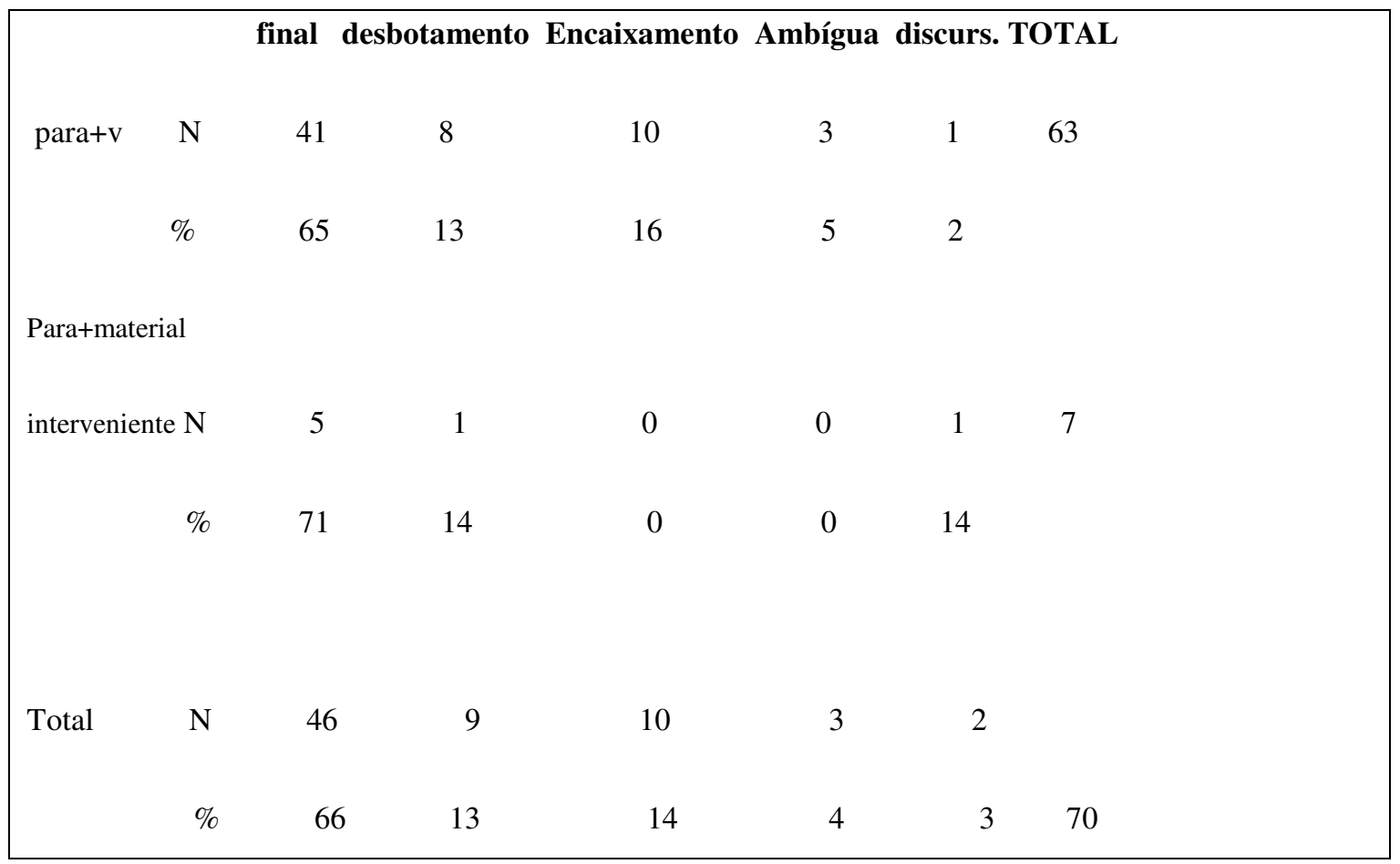

Tabela 7: Correlação Estrutura formal X valor semântico 
De acordo com a tabela acima, num total de 130 redações de vestibular da FUVEST, encontrei 70 dados da estrutura para + infinitivo, e como era de se esperar, as estruturas sem material interveniente são as mais freqüentes tanto na língua falada quanto na língua escrita. Assim, num total de 63 dados sem material interveniente, pude verificar que, embora 41 dados correspondem às estruturas prototípicas de finalidade, temos 22 dados que correspondem aos usos inovadores, no caso, 8 dados com desbotamento semântico, 10 dados que correspondem ao encaixamento, 3 dados de orações com ambigüidade pragmática e apenas 1 dado de oração discursiva. Com relação às estruturas para + material interveniente + verbo, embora foram encontradas apenas 7 dados, 2 desses dados corresponderam aos usos inovadores. O que verifiquei com a análise dos dados de língua escrita, é que mesmo em situação de necessidade da utilização da norma padrão, como é o caso de um dos vestibulares mais concorridos, as estruturas apresentam também usos que não os prototípicos.

\begin{tabular}{|c|c|c|c|c|c|c|c|}
\hline \multirow{3}{*}{ vazio } & & final & men & ixam & bígu & & \multirow[t]{3}{*}{ TAL } \\
\hline & $\mathrm{N}$ & 41 & 8 & 10 & 3 & 1 & \\
\hline & $\%$ & 65 & 13 & 16 & 5 & 2 & \\
\hline \multirow[t]{2}{*}{ Pron. } & $\mathrm{N}$ & 1 & 1 & 0 & 0 & 0 & \multirow[t]{2}{*}{2} \\
\hline & $\%$ & 50 & 50 & 0 & 0 & 0 & \\
\hline \multirow[t]{2}{*}{ Adv. } & $\mathrm{N}$ & 3 & 0 & 0 & 0 & 1 & \multirow[t]{2}{*}{4} \\
\hline & $\%$ & 75 & 0 & 0 & 0 & 25 & \\
\hline
\end{tabular}




\begin{tabular}{|cccccccc|}
\hline oração & $\mathrm{N}$ & 1 & 0 & 0 & 0 & 0 & \\
& $\%$ & 100 & 0 & 0 & 0 & 0 & 1 \\
& & & & & & & \\
Total & $\mathrm{N}$ & 46 & 9 & 10 & 3 & 2 & 70 \\
& $\%$ & 66 & 13 & 14 & 4 & 3 & \\
\hline
\end{tabular}

\section{Tabela 8: Correlação material interveniente $X$ valor semântico}

Assim como na língua falada, a maioria dos dados não apresenta material interveniente. De acordo com a tabela 8, apareceram 7 dados na forma para + material interveniente + verbo finito. O que foi observado é que 4 desses dados tinham como material interveniente um advérbio, principalmente o de negação. Dos 3 dados que se apresentaram nas forma prototípicas de finalidade, 1 se volta para a discursividade. Assim fica evidente que os dados de língua escrita também apresentam usos tão inovadores capazes de uma aproximação bastante interessante com língua falada. Dos dois dados que apresentaram como material interveniente um pronome, especificamente o pronome se, pude perceber que 1 desses dados também apresentava um uso inovador, no caso, um desbotamento de seu valor semântico de finalidade. Esta tabela também mostra como material interveniente uma oração, um uso que não apareceu nos dados de língua falada, mas não mostrou nenhuma alteração de seu valor prototípico.

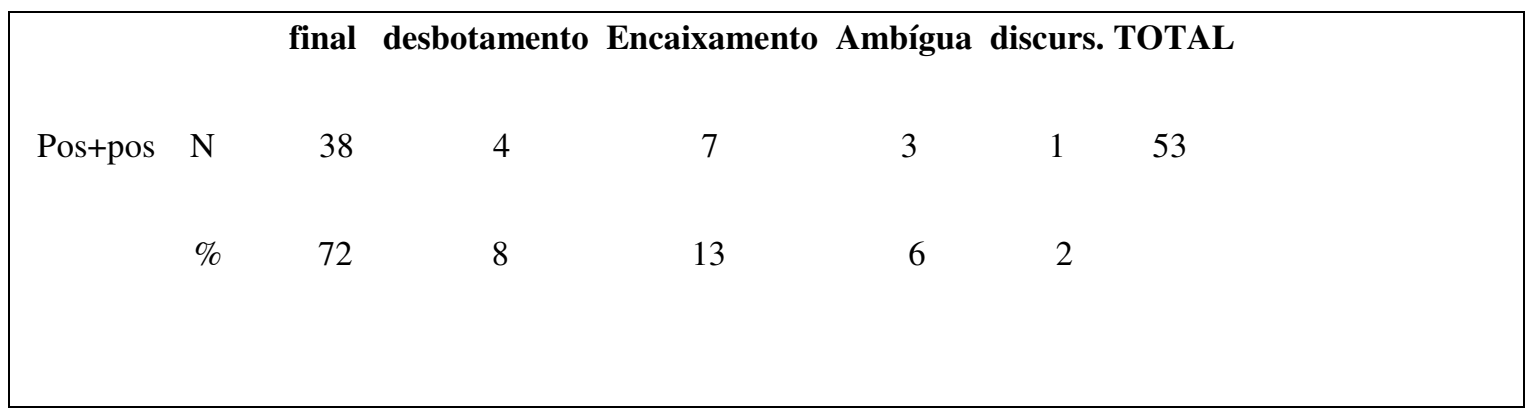




\begin{tabular}{|cccccccc|}
\hline Neg+pos & $\mathrm{N}$ & 6 & 5 & 3 & 0 & 0 & 14 \\
& $\%$ & 43 & 36 & 21 & 0 & 0 & \\
& & & & & & & \\
& & & & & & & \\
Pos+neg & $\mathrm{N}$ & 2 & 0 & 0 & 0 & 1 & 3 \\
& $\%$ & 67 & 0 & 0 & 0 & 33 & \\
& & & & & & & \\
Total & $\mathrm{N}$ & 46 & 9 & 10 & 3 & 2 & 70 \\
& $\%$ & 66 & 13 & 14 & 4 & 3 & \\
\hline
\end{tabular}

\section{Tabela 9: Correlação Polaridade X valor semântico}

De acordo com a análise dos dados de língua falada, a polaridade negativa tem influenciado bastante na alteração dos valores da estrutura para + infinitivo também nos dados de língua escrita. Embora encontrei apenas 14 dados na forma oração matriz negativa + oração para + infinitivo positiva, 8 dessas orações se desviaram do seu valor prototípico de finalidade, ou seja, mais da metade, eram usos inovadores, sendo que 5 dados apresentaram desbotamento semântico, e 3 dessas estruturas saíram do seu estatuto sintático prototípico de hipotáticas e passam a assumir o estatuto de subordinadas. Com relação aos dados onde a oração matriz é positiva e oração para + infinitivo é negativa, foram encontrados apenas 3 dados, sendo que 1 desses dados também apresenta um uso que não o prototípico de finalidade, mas voltado para a discursividade.

\begin{tabular}{|cccccccc|}
\hline \multicolumn{7}{c|}{ final } & desbotamento Encaixamento Ambígua discurs. TOTAL \\
modal & $\mathrm{N}$ & 1 & 1 & 0 & 0 & 0 & 2 \\
& $\%$ & 50 & 50 & 0 & 0 & 0 \\
\hline
\end{tabular}




\begin{tabular}{|c|c|c|c|c|c|c|c|}
\hline Ação fís .N & & 14 & 2 & 1 & 0 & 0 & 17 \\
\hline & $\%$ & 82 & 12 & 6 & 0 & 0 & \\
\hline Ação men & $\mathrm{N}$ & 4 & 1 & 0 & 1 & 0 & 6 \\
\hline & $\%$ & 67 & 17 & 0 & 17 & 0 & \\
\hline Estado & $\mathrm{N}$ & 3 & 1 & 2 & 1 & 0 & 7 \\
\hline & $\%$ & 43 & 14 & 29 & 14 & 0 & \\
\hline Percep. N & N & 1 & 0 & 0 & 0 & 1 & 2 \\
\hline$\%$ & $\%$ & 50 & 0 & 0 & 0 & 50 & \\
\hline Processo $N$ & N & 14 & 2 & 2 & 0 & 0 & 18 \\
\hline & $\%$ & 78 & 11 & 11 & 0 & 0 & \\
\hline Dicendi $I$ & $\mathrm{~N}$ & 1 & 1 & 1 & 0 & 1 & 4 \\
\hline & $\%$ & 25 & 25 & 25 & 0 & 25 & \\
\hline Conseguir & $\mathrm{N}$ & 8 & 1 & 4 & 1 & 0 & 14 \\
\hline & $\%$ & 57 & 7 & 29 & 7 & 0 & \\
\hline
\end{tabular}




\begin{tabular}{|cccccccc|}
\hline Total & $\mathrm{N}$ & 46 & 9 & 10 & 3 & 2 & 70 \\
& $\%$ & 66 & 13 & 14 & 4 & 3 & \\
\hline
\end{tabular}

\section{Tabela 10: Correlação verbo complemento da preposição $X$ valor semântico}

A fim de descobrir se os verbos que acompanham para podem ser uma das causas das alterações nos valores semânticos ou sintáticos das estruturas em estudo, também fiz a análise desses verbos.

Ao contrário do que foi observado na análise de língua falada, onde apareceram muitos dados com verbos modais depois de para, e que a maioria das estruturas para + verbo modal + verbo infinitivo apresentaram alterações sintáticas e semânticas, na língua escrita eles são evitados, pois foram encontrados apenas 2 dados. Dessa forma, na língua escrita, principalmente onde há uma pressão para que seja utilizada a norma culta, os verbos modais não são quase utilizados, e mesmo com poucos dados, ainda foi verificado que dos únicos dados encontrados, 1 deles apresentava um uso que não o prototípico, mas uma estrutura com desbotamento semântico, o que me leva a afirmar que os verbos modais podem ser um grande índice de alterações das estruturas para + infinitivo.

Com relação às estruturas infinitivas com verbos de ação física depois de para, dos 17 dados encontrados, apenas 3 eram usos inovadores, sendo que 2 desses dados apresentavam desbotamento semântico e 1 dado encaixamento, o que ratifica ainda mais o que já foi exposto nos dados de língua falada com relação aos verbos que indicam ações mais concretas.

As estruturas infinitivas com verbos de ação mental, estado e perceptivos depois de para apresentam poucos dados. Dos 6 dados encontrados de ação mental apenas 2 
eram usos inovadores, dos 7 dados de estado, apenas 3 não se enquadraram nos usos prototípicos, e dos 2 dados com verbos perceptivos, 1 era uso voltado para a discursividade.

Ao tratar de verbos processos depois de para, encontrei 18 orações, apenas 4 eram usos que não os prototípicos de finalidade, sendo que 2 dados eram orações com desbotamento semântico e 2 que apresentaram encaixamento sintático.

Ao tratar de dados com verbos dicendi após para, embora encontrei apenas 4 orações, 3 delas se enquadram em usos que não os prototípicos de finalidade, mas nos diversos usos, como desbotamento semântico, ambigüidade pragmática e discursivas. Desta forma, mais uma vez fica sustentada a minha intuição já exposta nos dados de língua falada quanto aos verbos que sinalizam evento particular e delimitação no tempo ${ }^{39}$.

No que diz respeito às estruturas para + verbo infinitivo com o valor de conseguir ou vencer encontrei um total de 14 dados, dos quais somente 6 apresentaram usos inovadores, e a maioria desses usos demonstraram alterações sintáticas, com 4 dados nos valores de encaixamento, assim, no restante, apenas 1 dado de cada outro respectivo uso, ou seja, desbotamento semântico e ambigüidade pragmática.

Pude perceber pela análise e disposição da tabela 4, que como na análise de língua falada, a maioria dos verbos que vem depois de para, são verbos de ação física e de processo, e como temos visto, estes carregam maiores índices de prototipicidade.

Os demais verbos depois de para embora apresentem uma quantidade menor de dados, nos mostram usos que não os prototípicos de finalidade, mas usos inovadores.

\footnotetext{
${ }^{39}$ Capítulo 3: Produtividade na língua falada:Padrões funcionais. Tabela 5 página 85.
} 


\begin{tabular}{|c|c|c|c|c|c|c|c|}
\hline \multirow[b]{2}{*}{ Suj.cor } & \multicolumn{7}{|c|}{ final desbotamento Encaixamento Ambígua discurs. TOTAL } \\
\hline &. $\mathrm{N}$ & 21 & 3 & 6 & 2 & 0 & 32 \\
\hline & $\%$ & 66 & 9 & 19 & 6 & 0 & \\
\hline Suj.não & $\mathrm{N}$ & 25 & 6 & 4 & 1 & 2 & 38 \\
\hline Corref & $\%$ & 66 & 16 & 11 & 3 & 5 & \\
\hline Total & $\mathrm{N}$ & 46 & 9 & 10 & 3 & 2 & 70 \\
\hline & $\%$ & 66 & 13 & 14 & 4 & 3 & \\
\hline
\end{tabular}

\section{Tabela 11: Correlação Sujeito sintático $X$ valor semântico}

Assim como nos dados de língua falada, a não correferencialidade entre sujeitos é muito importante para a determinação de usos mais gramaticalizados. No entanto, como se trata de dados de língua escrita, mais especificamente de redações de vestibular, onde a pressão para que a normatividade seja utilizada como grande fator para aprovação e bom resultado, como já era de se esperar, os usos inovadores não se mostram em quantidade tão grande como temos visto na análise de língua falada.

Desse modo, de acordo com a tabela acima, dos 32 dados encontrados de orações que apresentam correferencialidade entre os sujeitos da oração matriz e oração para + infinitivo, 21 eram usos prototípicos, contra apenas 11 dados de usos inovadores (3 orações com desbotamento semântico, 6 dados de encaixamento, e 2 dados que apresentavam ambigüidade pragmática). Dessa forma, embora as orações com sujeitos correferenciais apresentam uma quantidade maior de dados prototípicos de finalidade, 
também nos mostram usos inovadores com um processo de gramaticalização em andamento também nos dados de língua escrita.

Com relação à não correferencialidade de sujeitos, a tabela nos mostra uma quantidade um pouco maior de dados, sendo que das 38 orações encontradas, 25 delas eram orações adverbiais de finalidade, e embora apareceram apenas 13 dados de usos que não os prototípicos de finalidade, percebe-se que a não correferencialidade entre os sujeitos pode apresentar mais dados em que as estruturas para + infinitivo sofre um desbotamento semântico, pois dentre os dados de usos inovadores, 6 se enquadravam nesse subfator, e os demais se dividiam em 4 encaixadas, 1 ambígua e 2 discursivas.

O que fica evidenciado é que mesmo com toda a necessidade de se aplicar a norma culta, ainda assim encontramos dados em que as estruturas para + infinitivo apresentam usos inovadores e mais gramaticalizados. 


\title{
CAPÍTULO V
}

\author{
TRANSMISSÃO E INCORPORAÇÃO \\ DA NORMATIVIDADE \\ A ESTRUTURA PARA + INFINITIVO NA ESCOLA
}

\begin{abstract}
Neste capítulo será apresentado a aplicação de um teste sobre o uso preferencial dos conectores em orações finais. Para tal teste, foram selecionados alunos da $8^{\mathrm{a}}$ série do ensino fundamental e do $3^{\circ}$ ano do ensino médio com o objetivo de reconhecer a primeira opção dos informantes de uma geração mais nova, e confrontar com o que é esperado pelos autores dos livros didáticos, correlacionando esses resultados com variáveis de estratificação social verificando o peso da normatividade vinda dos livros didáticos. Ainda nessa seção, será apresentado aplicação dos resultados de um teste para professores de Língua Portuguesa com o objetivo de verificar se os mesmos são capazes de perceber as mudanças das estruturas para + infinitivo em seus aspectos sintático e semânticos.
\end{abstract}

\section{O USO PREFERENCIAL DOS CONECTORES EM ORAÇÕES FINAIS: A APLICAÇÃO DO TESTE.}

No capítulo em que mostro as estruturas para + infinitivo nas gramáticas ${ }^{40}$, é apresentada uma resenha sobre o que os gramáticos da norma culta dizem a respeito dessas estruturas e um estudo comparativo sobre como os livros didáticos têm abordado essa questão.

Como temos visto, nos livros didáticos e nas gramáticas de norma culta não há nenhum tipo de comentário ou observação sobre possíveis usos mais freqüentes e os já em desuso no português do Brasil; há, sim, a listagem dos conectores preferenciais: para que e a fim de que. Essa lista ficaria perfeitamente adequada na seção sobre conjunções, mas não na seção sobre orações subordinadas adverbiais finais. Explico: é evidente que as orações infinitivas antecedidas pela preposição para suplantam em

\footnotetext{
${ }^{40}$ Capítulo 2: Como a escola tem lidado com essa questão?.
} 
freqüência as demais opções. Assumem posição contrária os lingüistas, que afirmam categoricamente que as orações para + infinitivo são as mais recorrentes ${ }^{41}$.

Essa disparidade de informações deve-se à distância real entre o uso contemporâneo descrito e uso ideal previsto. Uma questão emerge dessa constatação: estariam os alunos, que recebem essa informação e são cobrados nesse sentido, empregando em situação de avaliação empregando esses conectores ideais ou estariam optando pelos usos mais freqüentes em situações de comunicação reais?

Para dar conta de entender o peso das informações veiculadas na escola sobre o comportamento lingüístico do aluno, adotei uma estratégia que chamo de "teste". Para dar conta dessa estratégia, conversei com professores de português e solicitei que aplicassem um exercício sobre conexão de orações durante a aula. Esses exercícios certamente me permitiriam reconhecer a preferência de uma geração mais nova, e essas respostas me serviriam de indicativo para avaliar a direção da mudança em curso.

Assim, elaborei um teste inspirado nos exercícios de fixação propostos pelos livros escolares ${ }^{42}$. Apresentando um rol de sentenças independentes, solicitava aos informantes que procedessem à ligação de duas porções isoladas:

(a) Precisamos formar um time. Assim, poderemos participar do campeonato.

(b) Deve-se investir em saúde e educação. Dessa forma, a situação dos brasileiros vai melhorar.

Alertava que o resultado dessa ligação deveria ser a finalidade e esperava que os alunos utilizassem, ainda não categoricamente, a locução para que. Essa esperança ou hipótese foi construída com base no resultado da comparação dos livros didáticos.

\footnotetext{
${ }^{41}$ Capítulo 2: Estrutura para + infinitivo: Pesquisas lingüísticas.

42 Os exercícios foram inspirados especificamente nos livros didáticos dos autores Cipro Neto e Infante (1997).
} 
Antes da aplicação do teste, uma das preocupações foi escolher informantes de diferentes idades e escolaridade. Tendo esses critérios claros, selecionei salas de aula em que havia alunos da $8^{\mathrm{a}}$ série do Ensino Fundamental, porque nessa série são ensinadas as orações adverbiais finais, e alunos do $3^{\circ}$ ano do Ensino Médio, pois já dominariam esse conhecimento e estariam passando por uma grande revisão desse conteúdo tendo em vista suas necessidades dos exames vestibulares.

Para essa aplicação, tivemos o cuidado de separar alunos de dois tipos diferentes de escola: uma escola estadual e uma escola privada. Com esse critério, era minha intenção confrontar as diferenças e a incorporação da normatividade em diferentes tipos de entidades educacionais, uma vez que podemos pressupor que as escolas particulares têm uma preocupação muito maior na transmissão da normatividade da língua.

Ambas as escolas têm os dois tipos de séries escolhidas para a aplicação do teste, no entanto parece haver uma diferença substancial entre as escolas selecionadas. A escola estadual tem como séries finais os terceiros anos do ensino médio, e a escola particular ainda conta com o seu ensino superior.

A Escola Santa Izildinha é uma instituição educacional que funciona desde 1954 e conta com os três períodos (manhã, tarde e noite), oferecendo cursos de graduação e de pós-graduação.

A Instituição conta com uma ótima infra-estrutura, dispondo de vários recursos para o melhor desempenho e aprendizado dos alunos. Há uma grande quantidade de salas de aula, laboratórios, bibliotecas, piscinas, entre outros espaços diferenciados. É uma escola que, embora fique localizada numa zona periférica de São Paulo (bairro de São Mateus) da zona leste de São Paulo, possui uma clientela de classe média-alta. A maioria de seus alunos tem como pais professores, dentistas e comerciantes. 
Um dos mais importantes critérios para a escolha de uma escola particular deste tipo derivou do sistema de ensino adotado. Desde o ensino infantil até o ensino médio, a instituição trabalha com o ensino apostilado Anglo, que é um método em que a normatividade e o ensino de língua portuguesa lida com a valorização do aprendizado da gramática normativa.

Para que pudesse traçar um paralelo entre diferentes tipos de aplicação da normatividade, senti a necessidade de escolher também uma escola estadual, em que o ensino e a abordagem da gramática é diferente de uma escola particular.

Assim, para a aplicação do teste, foi escolhida uma escola também na região de São Mateus, porém com uma clientela de classe social média-baixa. A escola Prof. João Camargo é uma escola em cuja vizinhança encontra-se uma favela, de onde grande parte dos alunos é proveniente.

Essa escola, ao contrário da outra particular, não conta com muitos tipos de recursos, possuindo apenas uma biblioteca, uma pequena sala de informática e uma sala de vídeo. Não é uma escola tão grande, mas possui 20 salas de aula, cada uma acolhendo aproximadamente 45 alunos.

A motivação para a escolha desse tipo de escola também se deve ao fato de que os alunos recebem do Estado livros didáticos para que realizem seus estudos. No caso do estudo de língua portuguesa, o livro adotado foi o dos autores Cereja \& Magalhães, anteriormente comparado com outros nesta pesquisa ${ }^{43}$. Assim, o teste foi aplicado a todos os alunos dessas duas séries escolares, e esse conjunto de informantes pode ser sintetizado assim:

\footnotetext{
${ }^{43}$ Cereja e Magalhães (2004).
} 


\section{Quadro 16 : Distribuição de informantes nas escolas básicas}

\begin{tabular}{|c|c|}
\hline Escola Santa Izildinha & EE.Prof. João Camargo \\
\hline Ensino fundamental $=74$ alunos & Ensino Fundamental = 45 alunos \\
\hline Ensino Médio = 52 alunos & Ensino Médio = 57 alunos \\
\hline
\end{tabular}

Retomando a formatação dos testes, elaborei dez exercícios com sentenças independentes para que os alunos procedessem à conexão da melhor forma possível. Durante a aplicação do teste, uma única orientação foi dada: as sentenças devem produzir o sentido de finalidade.

No que se refere à aplicação dos exercícios, montei um formulário de exercícios em cujo cabeçalho constava a orientação sobre o que deveria ser feito. Ao professor da sala foi dada a orientação para que não oferecesse exemplos aos alunos, a fim de que não se interferisse no resultado da conexão. O produto final dessa elaboração foi a seguinte:

Junte as duas frases apresentadas em uma só sentença de modo que o resultado
dessa ligação seja uma relação de finalidade:
1)Precisamos formar um time. Assim, poderemos participar do campeonato.
2)Deve-se investir em saúde e educação. Dessa forma, a situação dos brasileiros vai
melhorar.
3)É necessário usar o computador. Desse modo, agilizarei os cálculos.
4)O documento foi entregue ao presidente do júri. Assim, comprovaria a sua
autenticidade.
5)O menino muito se esforça. Dessa forma, obterá bons resultados.
6)Você precisa se comunicar melhor. Assim, chegará aonde quer.
7)Estuda muito. Assim, chegará a tocar um instrumento musical.
8)As pessoas idosas mudam de cidades. Assim, poderão ser sepultadas em paz.
9) Precisamos viajar. Desta forma, teremos uma vida menos estressante.
10) Os lavradores esperavam a chuva. Desta forma, não perderiam a colheita.




\section{O USO PREFERENCIAL DOS CONECTORES EM ORAÇÕES FINAIS: OS RESULTADOS.}

Assim, sem ter citado nenhum tipo de conector durante a aplicação do teste, o que de início foi observado é que a maioria dos alunos não conseguiu fazer a junção de todas as orações utilizando conectores adequados para a proposta.

Alguns, apenas juntaram as orações da mesma forma que foram dadas nos exercícios e outros, no caso de alunos da $8^{\mathrm{a}}$ série do ensino fundamental da escola estadual, conectaram as orações através de palavras discursivas, como em: "Você precisa se comunicar melhor aí chegará aonde quer", e outros utilizaram outros tipos de conectores que não os de finalidade ${ }^{44}$.

Quanto aos conectivos esperados para o valor de finalidade, de fato, também apareceram, de forma bastante restrita, para que, que e até mesmo a fim de que.

Para que fosse possível uma análise rigorosa dos dados para melhor compreensão dos resultados, lançamos dados de uma tabulação simplificada das respostas:

\section{Quadro 17 : Alunos da $8^{\mathrm{a}}$ série - Escola Particular}

\begin{tabular}{|c|c|c|}
\hline Tipos de oração & $n^{o}$ de orações & $\%$ \\
\hline para + infinitivo & 203 & 27,4 \\
\hline para que & 9 & 1,2 \\
\hline que & 8 & 1,1 \\
\hline a fim de & 8 & 1,1 \\
\hline outros conectores & 512 & 69,2 \\
\hline Total & 740 & 100 \\
\hline
\end{tabular}

\footnotetext{
${ }^{44}$ De acordo com a professora Nilza Barroso Dias, provavelmente "assim" e "dessa forma" podem ter causado interferências nos resultados obtidos no teste.
} 
Notemos que mais do que desconhecerem opções de conexão de orações de finalidade, os alunos apresentam outras deficiências que poderiam ser associadas à dificuldade de compreensão do enunciado ou mesmo o desconhecimento de como estabelecer conexão entre orações. Notemos que 512 testes representam a maioria dos dados analisados.

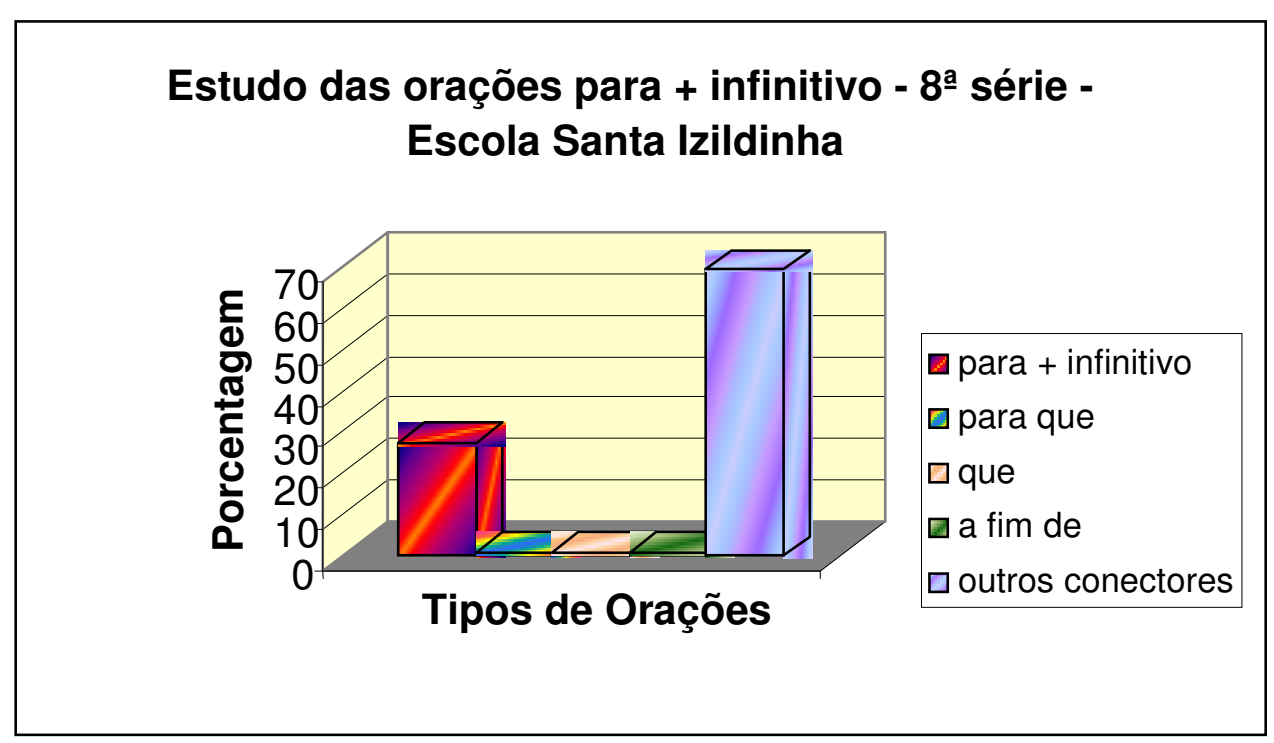

Gráfico 1: Teste de conexão - alunos do ensino fundamental

Com a representação gráfica dessa distribuição de dados, podemos perceber claramente que, embora os alunos tenham muita dificuldade em conectar orações através de conjunções, como já era de se esperar, os conectores selecionados pelos gramáticos como os mais recorrentes quase não aparecem nesse processo de junção. Os conectores para que, que e a fim de foram utilizados para conectar um total de 25 orações, o que representa apenas 3,4\% dos dados. No entanto, como era de se esperar, as orações para + infinitivo são, de fato, as mais recorrentes quando lidamos com orações de finalidade, contrariando o que dizem as gramáticas. Assim, num total de 740 orações a serem conectadas, os alunos utilizaram o conector para + infinitivo em 203, representando apenas $27,4 \%$ dos dados reunidos em teste. 
A maioria dos alunos não conseguiu utilizar os conectores esperados para o processo de finalidade. Dessa forma, aparecem como respostas ao teste de conexão os seguintes conectores: pois, como, assim, desse modo, então e até mesmo aí. Essas respostas revelam a grande dificuldade que os alunos têm em associar o conectivo escolhido com o processo semântico estabelecido entre as orações.

Na faixa escolar mais alta (ensino médio), os resultados foram os seguintes:

\section{Quadro 18 : Alunos do ensino médio - Escola Particular}

\begin{tabular}{|c|c|c|}
\hline \multicolumn{3}{|c|}{} \\
\hline Tipos de oração & $\boldsymbol{n}^{\boldsymbol{0}}$ de orações & \% \\
\hline para + infinitivo & 188 & 36,2 \\
\hline para que & 33 & 6,3 \\
\hline que & 13 & 2,5 \\
\hline a fim de & 2 & 0,4 \\
\hline outros conectores & 284 & 54,6 \\
\hline Total & 520 & 100 \\
\hline
\end{tabular}

Ainda que uma boa parcela das respostas (284 dados) demonstrem que o objetivo do teste foi frustrado dado a motivo não-investigado nesta dissertação, mas hipotetizado anteriormente como desconhecimento por parte dos alunos, uma parcela maior do que a apresentada no ensino fundamental estabeleceu adequadamente as conexões de finalidade, adotando estratégias diferenciadas num espectro já mais amplo de opções.

O gráfico desenha melhor esses resultados. Notemos que os alunos do ensino médio, embora de uma faixa etária maior, e em fase de ingresso no ensino superior, também apresentam uma grande dificuldade no exercício. De um total de 520 orações, 284 não foram conectadas da forma esperada, o que representa um montante de 54,6\% de orações com outros conectores que não os prototípicos de finalidade. 


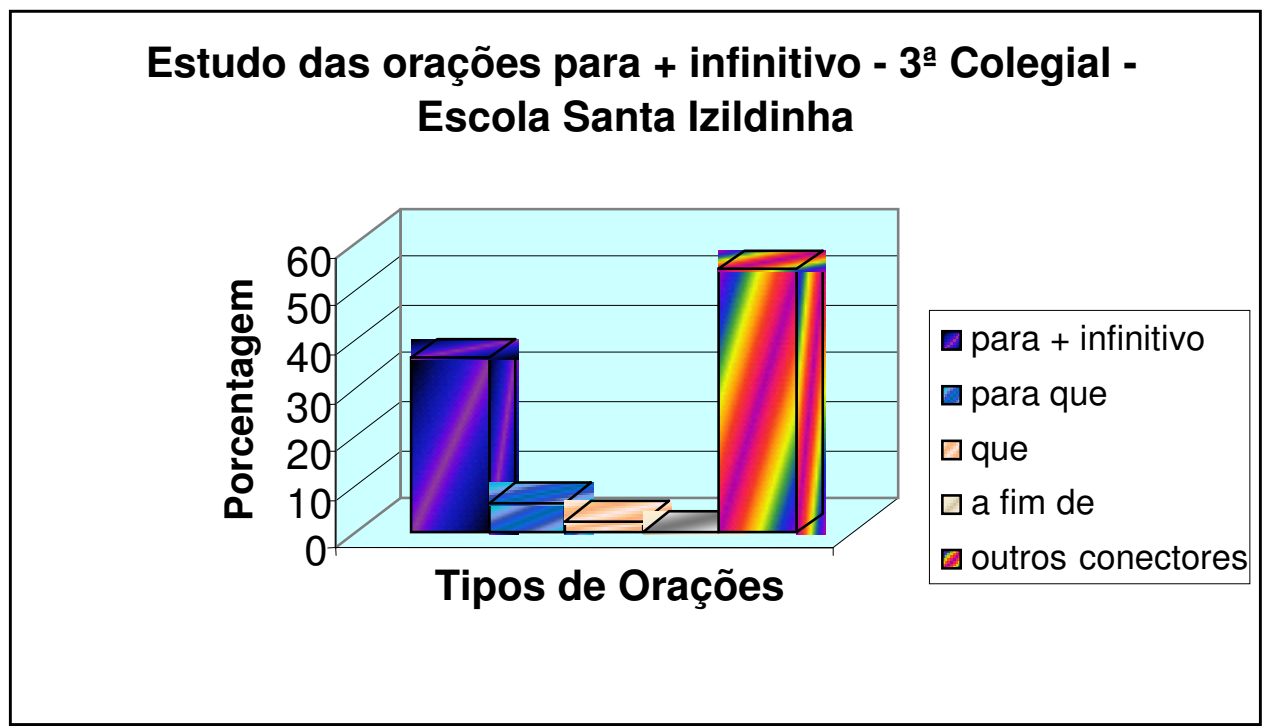

\section{Gráfico 2: Teste de conexão - alunos do ensino médio}

No entanto, embora tenham utilizado mais os conectores que, para que e a fim de, os quais somaram um total de 48 orações, ou seja, 9,2\% dos dados com o uso desses conectores, empregaram preferencialmente as orações para + infinitivo (188 casos), o que representa $36,2 \%$ dos dados, ou seja, uma quantidade maior de uso do que os alunos do ensino fundamental.

É senso comum entre professores de português que alunos do ensino público detêm desempenho inferior em relação aos de escola privada. Vejamos os resultados dos exercícios realizados por esses alunos de escola estadual:

\section{Quadro 19: Alunos da 8a série - Escola Pública}

\begin{tabular}{|c|c|c|}
\hline Tipos de oração & $n^{o}$ de orações & $\%$ \\
\hline para + infinitivo & 126 & 28 \\
\hline para que & 19 & 4,2 \\
\hline a fim de & 8 & 1,8 \\
\hline outros conectores & 297 & 66 \\
\hline Total & 450 & 100 \\
\hline
\end{tabular}

O que se pode depreender desses resultados é que não há muita diferença dos resultados entre ambas escolas. Os alunos de escola pública equiparam-se aos outros, 
pois também apresentam dificuldade em conectar orações, mantendo o valor semântico proposto no exercício.

De um total de 450 orações conectadas, 297 não utilizaram nenhum dos conectores que eram esperados, o que representa $66 \%$ de orações com uso de outros tipos de conectores. Como podemos perceber também, nenhum aluno conectou as orações com o conectivo que.

No entanto, os dados confirmam a preferência em conectar orações de finalidade através da estrutura para + infinitivo, o que representa um número bastante considerável, ou seja, 126 orações conectadas dessa forma, representando um total de $28 \%$ dos dados dentro das opções de finalidade apresentadas. Esses resultados podem ser melhor visualizados no gráfico seguinte:

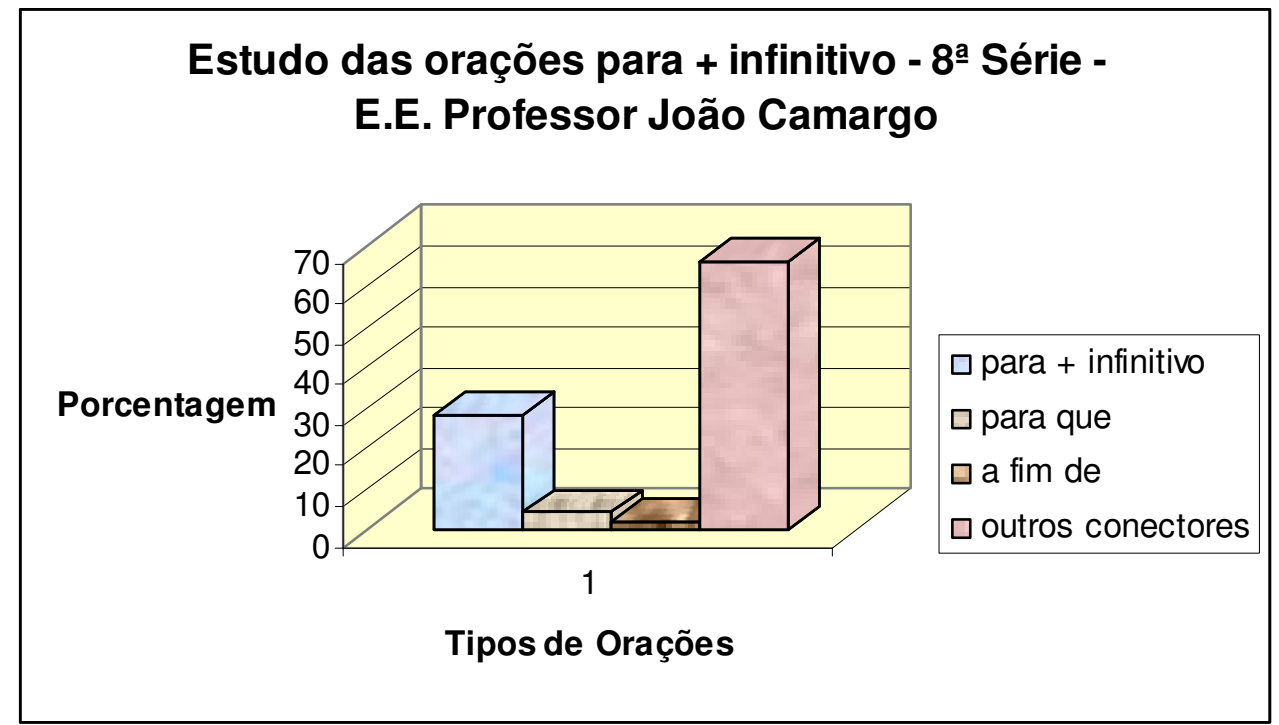

Gráfico 3: Teste de conexão - alunos do ensino fundamental

Com relação ao ensino médio da escola particular, os resultados se apresentaram distribuídos da seguinte maneira: 


\begin{tabular}{|c|c|c|}
\hline \multicolumn{3}{|c|}{$\begin{array}{c}\text { Alunos } 3^{\boldsymbol{a}} \text { Colegial - E.E. Prof. João } \\
\text { Camargo }\end{array}$} \\
\hline Tipos de oração & $\boldsymbol{n}^{\boldsymbol{o}}$ de orações & $\%$ \\
\hline para + infinitivo & 146 & 25,6 \\
\hline para que & 21 & 3,7 \\
\hline a fim de & 40 & 7 \\
\hline outros conectores & 363 & 63,7 \\
\hline Total & 570 & 100 \\
\hline
\end{tabular}

Os alunos do $3^{\circ}$ colegial do Ensino Médio da Escola Estadual, também apresentam resultados não muito diferentes dos apresentados pelos alunos da Escola Particular, pois como em todos os anteriores, a maioria das orações foram conectadas com outros conectores que não os de finalidade, representando um total de $63,7 \%$, ou seja, das 570 orações conectadas, 363 não utilizaram para que, a fim de ou para + infinitivo.

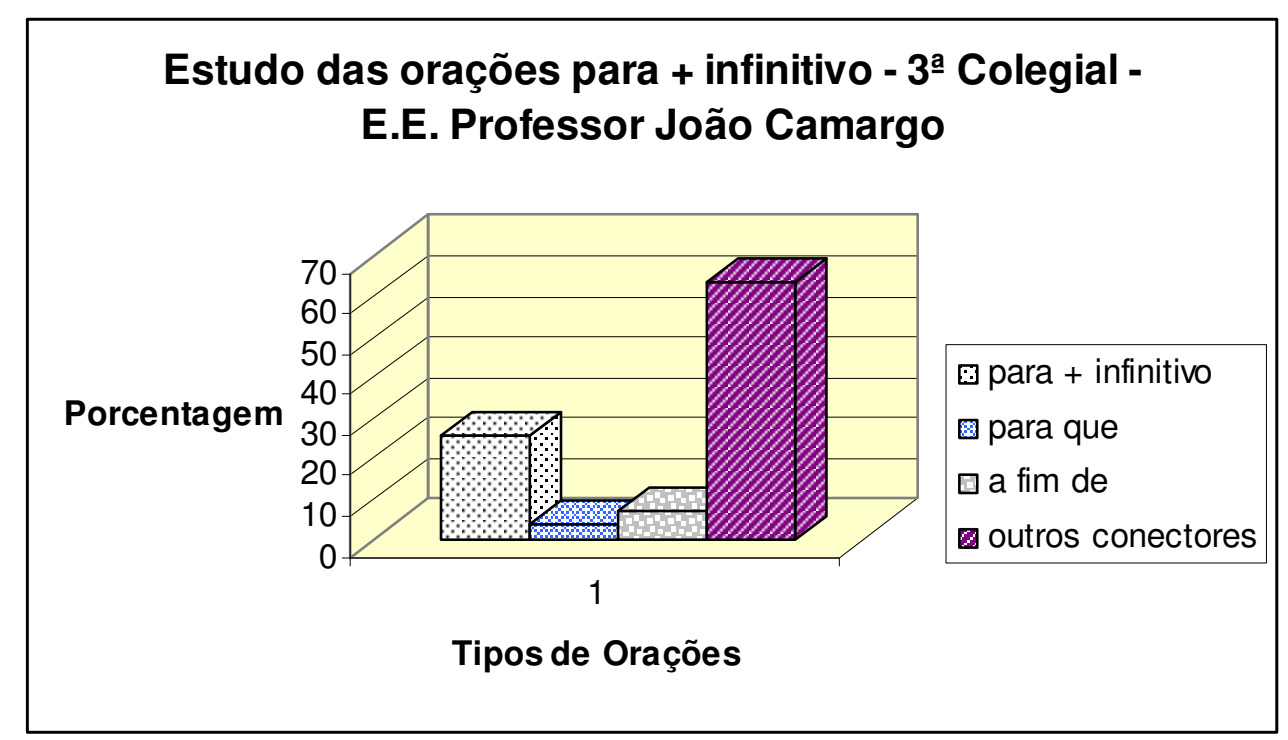

\section{Gráfico 4: Teste de conexão - alunos do ensino médio}

Os conectores pra que e a fim de foram utilizados em 61 orações, o que é o maior número apresentado até então, representando $10,7 \%$ de orações. O conector a fim de aparece em 40 orações, no entanto 10 orações foram conectadas pelo mesmo aluno. 
Ainda assim, fica bem nítido que o uso preferencial recai sobre a estrutura para + infinitivo, que num total de 570 orações, representou uma porcentagem de $25,6 \%$ do uso, ou seja, 146 orações foram conectadas com este tipo de estrutura, o que é um número bastante considerável.

Durante a tabulação dos dados do ensino médio da escola particular, uma intuição com relação aos resultados exigiu que eu checasse a disparidade de respostas entre meninos e meninas.

Os alunos das $8^{\mathrm{a}} \mathrm{s}$ séries do Ensino Fundamental de ambas escolas não manifestaram nenhuma diferença significativa entre os empregos efetuados por ambos os sexos. Manteve-se o uso preferencial pelas estruturas para + infinitivo, sendo que os demais conectores foram pouco utilizados e na mesma proporção.

Quanto ao Ensino Médio da Escola Estadual, também não foi constatada nenhuma diferença significativa dos resultados entres ambos os sexos dos informantes, porém um resultado diferente se dá no $3^{\circ}$ ano do colegial dos alunos da Escola Particular:

\section{Quadro 21 : Alunos do ensino médio - Meninos}

\begin{tabular}{|c|c|c|}
\hline \multicolumn{3}{|c|}{ Alunos $3^{\boldsymbol{o}}$ Ano E.M. (meninos) - Escola Santa } \\
Izildinha
\end{tabular}




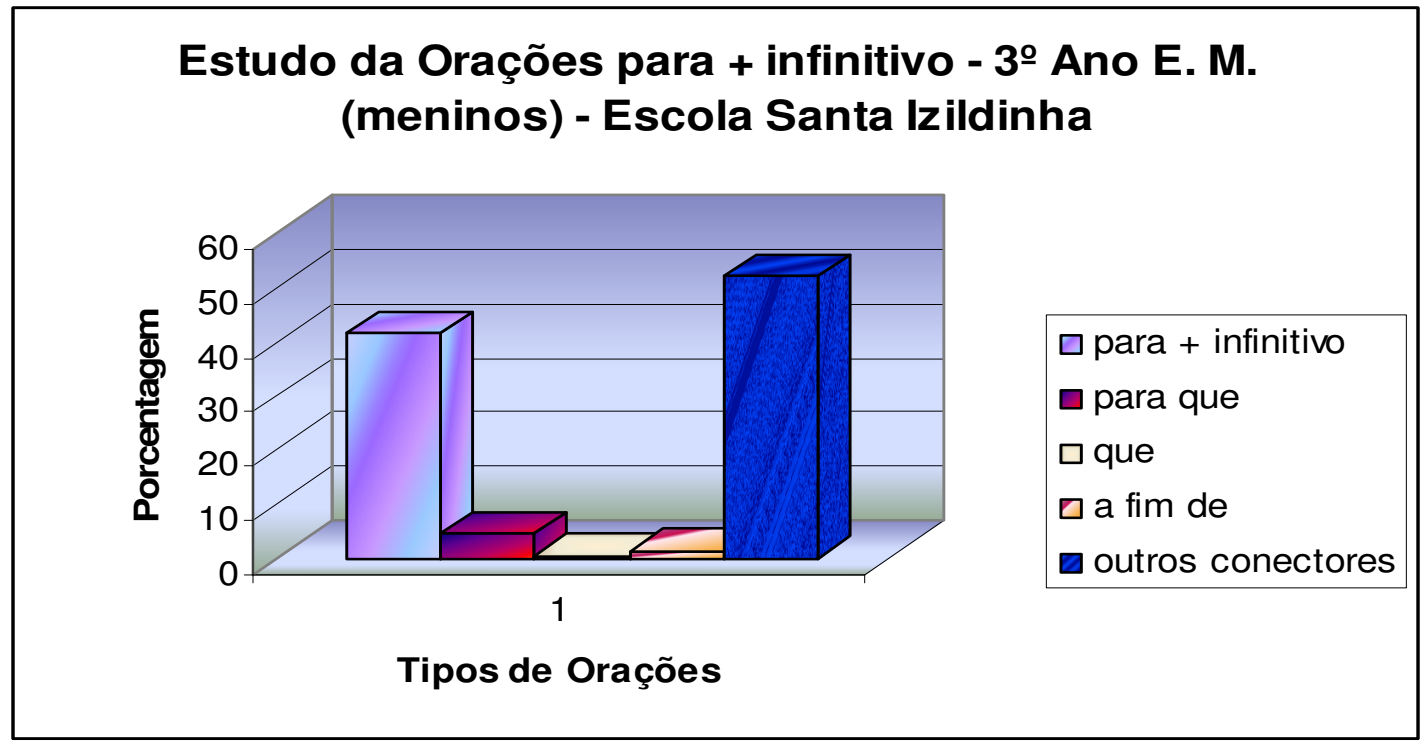

Gráfico 5: Teste de conexão - meninos do ensino médio

Quadro 22: Alunos do ensino médio - Meninas

\begin{tabular}{|c|c|c|}
\hline \multicolumn{3}{|c|}{ Alunos $3^{\boldsymbol{o}}$ Ano E.M. (meninas) - Escola Santa } \\
Izildinha
\end{tabular}

Com esses resultados, vemos que as meninas de uma escola particular, em que é valorizada a norma culta, apresentam um uso muito maior das estruturas para que, que e a fim de. 


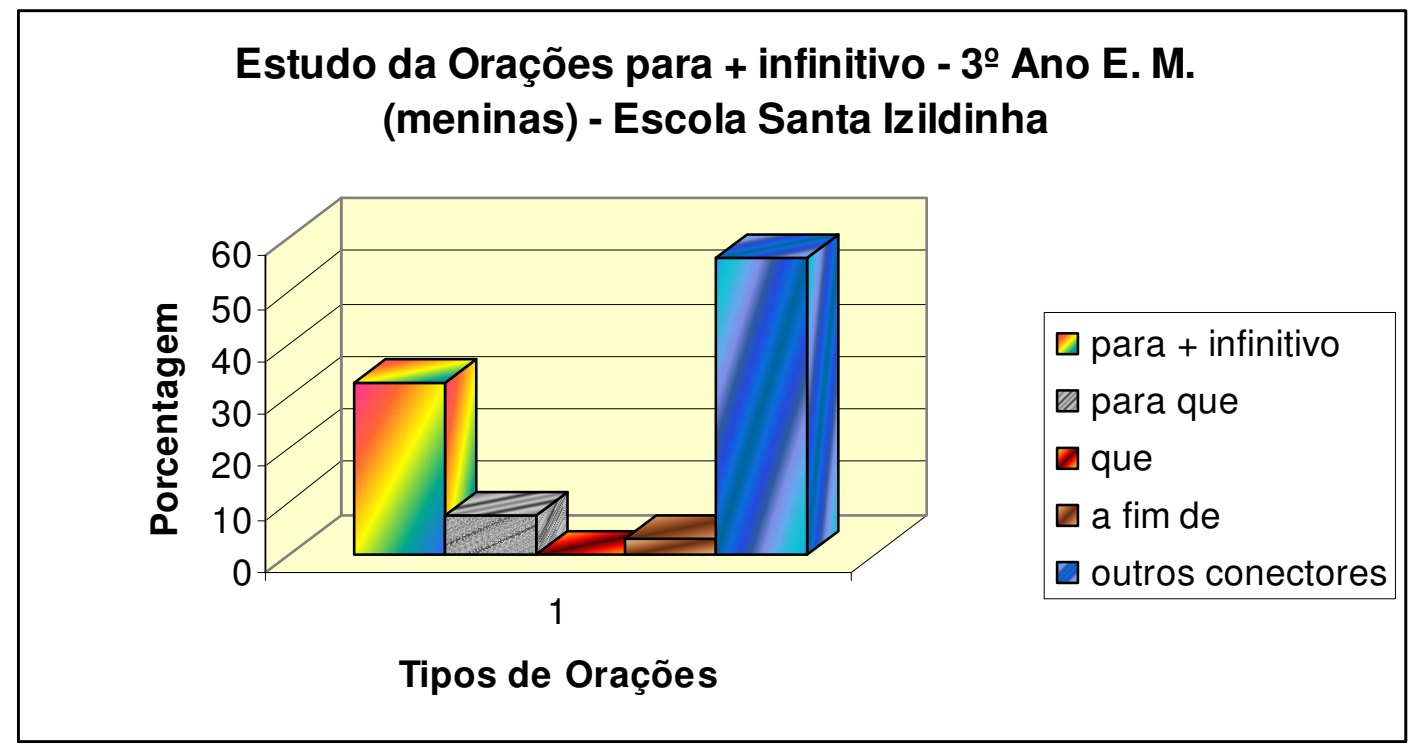

\section{Gráfico 6: Teste de conexão - meninas do ensino médio}

Observa-se que embora ambos os sexos usem em maior quantidade as estruturas para + infinitivo, o que representa para os meninos $41,5 \%$ e $32 \%$ para as meninas, os meninos utilizam apenas $6,5 \%$ dos conectores para que, que e a fim de, enquanto as meninas utilizam $10,9 \%$ dos conectores mais prestigiados nas gramáticas normativas. Isso pode ser de fato uma ratificação dos que pregam os sociolingüistas quanto à afirmação de que as meninas fazem mais uso da norma considerada culta.

De acordo com todos os resultados, num apanhado geral, foi possível constatar que os alunos de ambas as escolas e das diferentes faixas etárias possuem uma dificuldade imensa em reconhecer e estruturar valores semânticos na língua materna. Assim, o que a gramática e os livros escolares têm feito até o momento é reconhecer essa dificuldade e simplesmente facilitar para o aluno com exercícios que emitam respostas totalmente previsíveis aos exercícios propostos. É inegável que os livros didáticos - e os professores em sala de aula - privilegiam o exercício automatizado de preenchimento, não fornecendo meios para que os alunos pensem acerca da correlação estrutura/valor semântico. O exercício simplesmente cobra a conexão em moldes prontos, uma repetição de padrões. 
Livros didáticos são, dessa forma, uma pausa da aula; apenas exercícios momentâneos, respondidos mecanicamente, e isso não tem efetivamente garantido o raciocínio lógico e a assimilação por parte dos discentes.

Os conectores que, para que e a fim de, embora sejam propostos nos exercícios dos livros escolares, não são comuns na língua falada dos alunos. Os alunos tomam, portanto, como modelo de escrita a língua que falam. Essa interferência de modalidades certamente pode atuar como gatilho de mudança lingüística, como já argumentaram Heine, Claudi \& Hünnemeyer (1991) em seu estudo sobre as línguas africanas.

Assim, com tantas fragilidades no sistema de ensino do português, as mudanças na língua são disparadas. A dificuldade em reconhecer as divergências e as ambigüidades pragmáticas são cada vez maiores, justamente porque a escola abandonou o ensino da gramática em sua vertente reflexiva, e um indício disso é o estudo da semântica.

Dessa forma, é de grande importância verificar se esta dificuldade em reconhecer os diversos valores semânticos que as estruturas para + infinitivo podem apresentar são apenas dos alunos ou se os educadores também sentem dificuldades quando se trata de reconhecer diversidades semânticas e sintáticas das estruturas.

Para que eu possa responder a essa questão, elaborei um teste de interpretação com os professores de escola básica. Apresento a seguir um teste com diferentes tipos de estruturas para + infinitivo, com o objetivo de verificar se os professores estão atentos às mudanças sintáticas e semânticas pelas quais estas estruturas estão passando. 


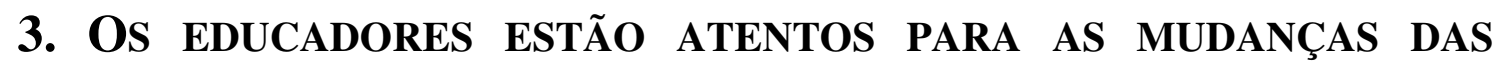

\section{ESTRUTURAS PARA + INFINITIVO?}

As gramáticas não abarcam todas as mudanças que acontecem na língua, porque as línguas são dinâmicas e as gramáticas (livros) veiculam conteúdos de específicos escolhidos pelos normatizadores. Essa combinação gera um impasse ao ensino.

Os professores continuam passando o mesmo conteúdo que aprenderam quando eram alunos do ensino básico, e os alunos revelam dificuldade em compreender o estatuto sintático e semântico de estruturas, porque se orientam pela língua falada.

Falar de sintaxe, ou dos demais usos gramaticais tendo como base os livros didáticos faz com que professores se coloquem "entre a cruz e a espada", pois devem decidir se falam de temas inovadores, de aspectos da dinamicidade da língua (mais próximos dos usos dos alunos) ou se reproduzem a normatividade (mais próxima da realidade profissional dos docentes).

Alunos não compreenderão jamais por que devem classificar como oração subordinada adverbial de finalidade um exemplo, como "Existem espetáculos de sexo para o público discutir". Também professores não conseguem encontrar nos livros e gramáticas nomenclatura que resolva esse problema.

Com base nesse dilema, nesta seção, apresento os resultados de um teste realizado com professores de diversas instituições escolares. Era meu objetivo identificar se, de fato, os professores conseguem identificar essas mudanças tanto sintáticas quanto semânticas pelas quais as estruturas para + infinitivo estão passando.

O teste foi aplicado tanto a professores experientes (com mais de 10 anos de magistério) quanto a professores iniciantes (com menos de 2 anos de magistério). Era minha intenção nesse controle verificar se os mais jovens teriam maior sensibilidade 
para a questão, pois em seus recentes estudos universitários teriam contato com estudos sobre variação e mudança lingüística.

O teste envolveu 4 homens e 11 mulheres, isto pelo fato de que com relação à disciplina de língua portuguesa, temos uma quantidade muito maior de professoras do que de professores. O objetivo seria verificar se haveria diferença entre os educadores do sexo masculino e do sexo feminino em identificar as mudanças sintáticas ou semânticas das orações em para + infinitivo.

Para a aplicação do teste, foram utilizadas orações do próprio corpus $^{45}$ e do livro didático dos autores Cereja \& Magalhães (2004), para que houvesse uma mistura de frases oriundas da língua falada e da língua escrita, uma vez que as mudanças não estão somente na fala.

Com a preocupação de deixar tão óbvia a intenção do teste, não foram selecionadas além de estruturas para + infinitivo e outras orações de finalidade, também orações adverbiais causais, temporais e comparativas. Desta forma, foram apresentadas aos professores um total de 10 frases, dentre as quais havia somente uma era conectada com a locução a fim de que, e seis orações com a estrutura para + infinitivo que incluíam casos de ambigüidade pragmática, desbotamento semântico (valor semântico de finalidade e condição) e até mesmo estruturas com seu valor sintático alterado, como é o caso das encaixadas.

O formulário do teste foi apresentado da seguinte maneira:

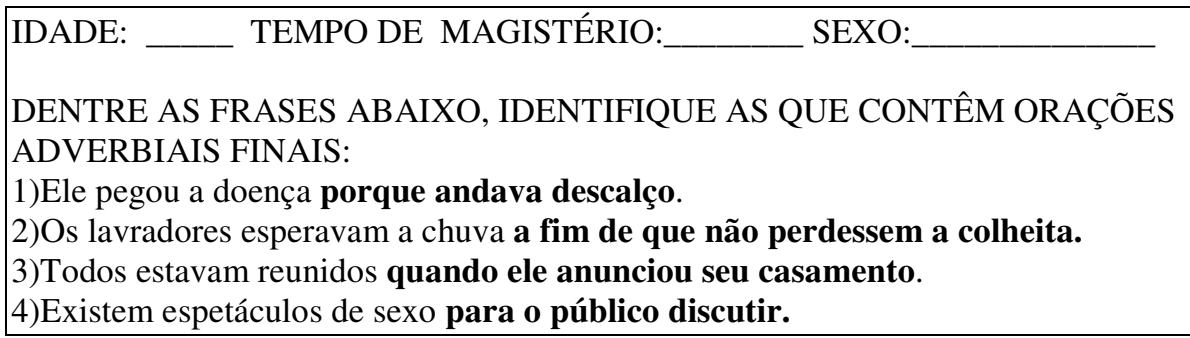

${ }^{45}$ Exemplos retirados do projeto NURC e de redações da FUVEST. 


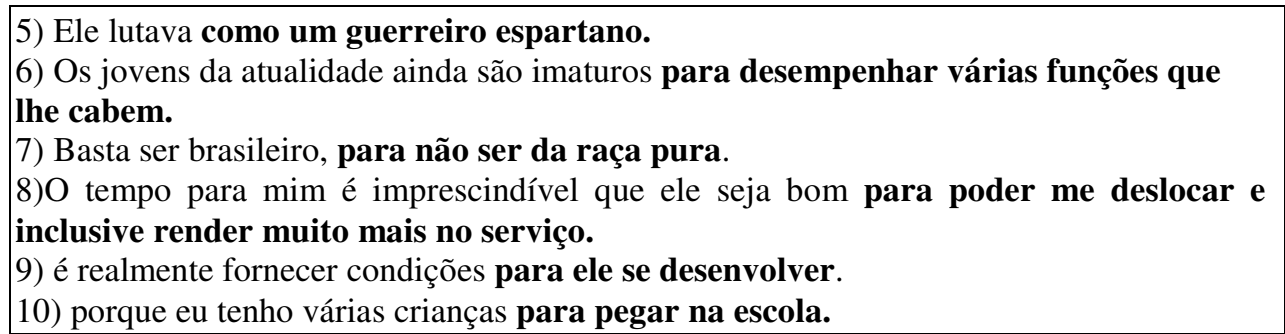

Como era de se esperar, a dúvida e as dificuldades em compreender e analisar as orações para + infinitivo não são somente dos alunos, mas também dos educadores, uma vez que presos às gramáticas e aos livros didáticos não conseguem acompanhar as mudanças e inovações que estão acontecendo na nossa língua.

Desta forma, foi montada uma tabela para que melhor pudéssemos visualizar quais foram os resultados obtidos, e se os educadores incluíram algum tipo de comentário que denunciasse o reconhecimento das divergências tanto semânticas quanto sintáticas que as estruturas para + infinitivo apresentam, e não simplesmente associando-as ao valor de finalidade como pregam as gramáticas normativas e os livros escolares.

O quadro seguinte permite conhecer cada uma das orações incluídas no teste e como foram classificadas pelos professores. Também é possível conhecer a divisão de faixa etária e de tempo de experiência no magistério:

Quadro 23 : Informantes docentes

\begin{tabular}{|l|l|l|l|}
\hline Informantes & Faixa etária & Sexo & Tempo de magistério \\
\hline Informante 1 & 24 anos & masculino & 3 anos \\
\hline Informante 2 & 41 anos & masculino & 16 anos \\
\hline Informante 3 & 23 anos & feminino & 1 ano \\
\hline Informante 4 & 40 anos & feminino & 8 anos \\
\hline Informante 5 & 25 anos & feminino & 1 ano \\
\hline Informante 6 & 40 anos & feminino & 20 anos \\
\hline Informante 7 & 38 anos & feminino & 16 anos \\
\hline
\end{tabular}




\begin{tabular}{|l|l|l|l|}
\hline Informante 8 & 25 anos & feminino & 5 anos \\
\hline Informante 9 & 29 anos & feminino & 1 ano \\
\hline Informante 10 & 41 anos & masculino & 16 anos \\
\hline Informante 11 & 39 anos & masculino & 8 anos \\
\hline Informante 12 & 36 anos & feminino & 14 anos \\
\hline Informante 13 & 56 anos & feminino & \\
\hline Informante 14 & 31 anos & feminino & 5 anos \\
\hline Informante 15 & 44 anos & feminino & 18 anos \\
\hline
\end{tabular}

Assim, apresentando os resultados através de um quadro, podemos depreender uma série de informações interessantes:

\section{Quadro 24: Resultados de associações docentes}

\begin{tabular}{|c|c|c|}
\hline \multicolumn{3}{|c|}{ associaram ao valor de finalidade } \\
\hline ORAÇÕES & SEXO: MASCULINO & SEXO: FEMININO \\
\hline $1^{\mathrm{a}}$ oração & Informante 1 & Informante 4 \\
\hline $2^{\mathrm{a}}$ oração & Informantes $1,2,10$ e 11 & Informantes $4,5,6,7,8,9,12,13,14$ e 15 \\
\hline $3^{\mathrm{a}}$ oração & Nenhum informante & Nenhuma informante \\
\hline $4^{\mathrm{a}}$ oração & Informantes $1,2,10$ e 11 & Informantes $4,5,6,7,8,9,13$ e 14 \\
\hline $5^{\mathrm{a}}$ oração & Informante 1 & Nenhuma informante \\
\hline $6^{\mathrm{a}}$ oração & Informantes 2 e 10 & Informantes $4,6,7,8,13$ e 15 \\
\hline $7^{\mathrm{a}}$ oração & Nenhum informante & Informantes 4,6 e 8 \\
\hline $8^{\mathrm{a}}$ oração & Informantes 2 e 10 & $\begin{array}{l}\text { Informantes } 5,6,8,9,12,13 \text { e } 14 \\
\text { Obs.: a informante } 3 \text { associou com } \\
\text { oração consecutiva. }\end{array}$ \\
\hline $9^{a}$ oração & Informantes $1,2,10$ e 11 & $\begin{array}{l}\text { Informantes } 5,7,8,9,12,13 \text { e } 14 \\
\text { Obs.: a informante } \mathbf{3} \text { associa ao valor de } \\
\text { condição. }\end{array}$ \\
\hline $10^{\mathrm{a}}$ oração & Nenhum informante & Informantes 4,6 e 8 \\
\hline
\end{tabular}

No primeiro exercício, foi apresentada uma oração retirada do livro didático dos autores Cereja \& Magalhães (2004), pelos quais é classificada como uma oração adverbial causal, no entanto, temos ainda dois informantes que associaram essa estrutura ao valor de finalidade.

Podemos explicar esse tipo de análise ao pouco tempo de magistério ou até mesmo por não estarem em contato com tal tipo de análise sintática. Alguns professores 
alegam, que pelo fato de trabalharem apenas com séries iniciais, quase não lidam mais análise sintática, ou análise de estruturas complexas.

$\mathrm{Na}$ segunda oração, o fato de conectarmos orações com a fim de, o que esperávamos é que os professores fizessem a associação desse tipo de estrutura com o valor de finalidade, ainda que houvesse ali uma ambigüidade interpretativa, como já demonstrei anteriormente ${ }^{46}$. Os informantes não perceberam ou pelo menos não deixaram qualquer comentário a respeito. $\mathrm{O}$ teste, na verdade, não pedia que comentassem, apenas pedia que identificassem a presença de orações finais. Apenas a informante 3, que não identificou a oração de finalidade, anotou que havia ali uma oração concessiva.

A terceira oração, também retirada do livro didático de Cereja \& Magalhães (2004), não foi associada por nenhum informante como sendo adverbial de finalidade. Na verdade, tratava-se de uma oração adverbial temporal, uma noção cognitivamente mais básica e por isso mesmo de mais fácil reconhecimento para os testados.

A oração de número quatro, retirada do corpus deste trabalho ${ }^{47}$, embora sintaticamente detenha estrutura de oração adverbial de finalidade, apresenta semanticamente um problema: é pragmaticamente ambígua, admitindo também o valor de finalidade. Os resultados mostram que apenas os informantes 3 e 12 não associaram esta oração ao rol das adverbiais finais. O que percebo, neste caso, é que o número 3 é um informante com menos tempo de magistério, e seu comportamento tanto poderia denunciar o reconhecimento de uma oração não-prototipicamente final quanto um equívoco de análise. Já, os informantes 1, 2, 4 5, 6, 7, 8, 9, 10, 11, 13 e 14, talvez mais

\footnotetext{
${ }^{46}$ Capítulo 2, \&2.2: Como a escola tem lidado com esta questão?, página 25. Neste capítulo é apresentado uma ambigüidade com relação a esta oração que é mostrada no livro de Ernani Terra e José de Nicola (2004).

${ }^{47}$ Corpus retirado do projeto NURC/SP.
} 
embebidos de uma tradição, não perceberam tal ambigüidade interpretativa, classificando a oração como final.

O exercício de número cinco foi retirado de um exemplo também fornecido pelo livro didático dos autores Cereja \& Magalhães (2004), que classificam a oração como adverbial comparativa. Lembramos que a comparação também é uma operação básica ao ser humano, por isso mesmo de fácil reconhecimento. Apenas o informante de número 1 fez a associação dessa oração com finalidade. $\quad \mathrm{O}$ exercício de número 6 foi extraído do corpus de língua escrita deste trabalho ${ }^{48}$ e, como podemos observar, embora seja classificada sintaticamente como adverbial e semanticamente como final, essa oração apresenta certa divergência semântica, pois não é tão nítido um valor de finalidade para esta estrutura. Nem todos os informantes, no entanto, perceberam tal divergência; apenas os informantes $1,3,5,9,11,12$ e 14 não fizeram a associação desta oração com o valor de finalidade e, como podemos verificar, mais uma vez, com exceção do informante 12, os demais são os que detêm menor tempo de magistério, ou seja, a maioria com apenas um ano, e os demais com menos de oito anos, o que nos faz supor que ainda possam não estar tão presos às idéias veiculadas nos livros escolares.

Em situação diversa a desses professores estão os que associaram o exercício de número 6 ao valor de finalidade. Estes professores detêm mais de 10 anos de magistério (informantes $2,10,4,6,7,8,13$ e 15), o que permitiria supor que estão mais próximos do conteúdo veiculado em livros didáticos, refletindo uma incorporação de valores sintáticos espelhada no que as gramáticas escolares propõem.

O exercício de número sete, retirado também de amostra de língua escrita deste trabalho $^{49}$, apresenta ambigüidade pragmática. No entanto, de forma bastante

\footnotetext{
${ }^{48}$ Exercício retirado das redações de vestibular da FUVEST (1999).

${ }^{49}$ Exercício retirado das redações de vestibular da FUVEST (2001).
} 
interessante, embora seja uma estrutura semelhante à apresentada no exercício anterior, a maioria dos informantes não associou ao valor de finalidade (trata-se dos informantes $4,6$ e 8$)$.

A leitura conjunto de todos os resultados parece ratificar o grande problema que nos trazem as estruturas para + infinitivo com polaridade negativa, provocando divergentes interpretações e desvinculando essas orações do seu valor prototípico de finalidade.

O exercício número oito foi retirado da amostra de língua falada ${ }^{50}$ e apresenta desbotamento semântico ${ }^{51}$. O seu valor combinado com condição torna opaca a interpretação, o que notei com as respostas aos testes dos informantes 1, 3, 4, 7 e 11. Em oposição aos demais, a informante 7 é iniciante na profissão.

O exercício de número nove foi retirado do próprio corpus de língua falada desta pesquisa $^{52}$ e apresenta um processo de gramaticalização bastante intenso da estrutura para + infinitivo, assumindo o estatuto de oração encaixada. A despeito dessa grande diferença de comportamento, somente os informantes $1,3,4,7$ e 11 perceberam que não se tratava de finalidade. É relevante saber que a informante de número 3 possui apenas um ano de magistério. Esta docente associou a estrutura a um valor condicional. Provavelmente fez a associação semântica da seguinte forma: "para se desenvolver, deve-se fornecer condições". No entanto, os demais educadores não perceberam nenhuma divergência nem semântica nem sintática, e apenas seguiram mais uma vez o que as gramáticas e os livros escolares propõem.

O exercício de número dez também é um exemplo retirado das amostras de língua falada deste trabalho, também é uma estrutura que apresenta ambigüidade

\footnotetext{
${ }^{50}$ Exercício retirado da amostra de língua falada do projeto NURC/SP.

${ }^{51}$ Capítulo 3: Amostras de língua falada: Análise dos dados.

${ }^{52}$ Amostras de língua falada do projeto NURC/SP.
} 
pragmática. Nesse caso, a grande maioria dos informantes também não teve problemas em não assinalar as frases, o que significou o não reconhecimento de finalidade na estrutura. Somente os informantes 4, 6 e 8 fizeram essa associação. O informante de número 6 é o informante com mais tempo de magistério, o que pode ser um fator para não perceber tal ambigüidade, uma vez que, como já foi afirmado anteriormente, pode ter sua leitura condicionada pela lida diária nos moldes de gramática tradicional.

Alguns casos de estrutura para + infinitivo são tão divergentes, como é o caso dos exercícios 7 e 10, que até mesmo os professores habituados ao ensino de gramática normativa e ao domínio de conteúdos dispostos nos livros escolares já não percebem mais valores de finalidade nas estruturas. Talvez isso sinalize que quanto maior for a gramaticalização, maior se torne a visibilidade para o analista especializado, como é o caso do professor.

Essa facilidade não se apresenta, no entanto, para a grande maioria dos educadores. Estes, distantes do trabalho reflexivo, recuperam as normas gramaticais para a análise sem qualquer questionamento.

Em suma, o prejuízo que traz o trabalho pouco crítico por parte dos docentes e, como reflexo disso, dos discentes é, guardadas as devidas proporções, o desconhecimento da própria língua. Urge que professores se dispam da leitura normativista e passe a assumir uma posição mais crítica, só assim o ensino de língua portuguesa assumirá seu verdadeiro estatuto de um ensino eficiente. 


\section{CONSIDERAÇÕES FINAIS}

Pela discussão e análise desenvolvidas durante este trabalho, evidenciei que as estruturas para + infinitivo têm passado por um forte e intenso processo de mudança e inovações e que esse processo não tem sido acompanhado de perto pela escola.

No capítulo 1, apresentei os pressupostos da gramaticalização que fundamentam este trabalho. Mostrei que as estruturas infinitivas antecedidas pela preposição para têm revelado uma ambigüidade interpretativa, derivada de alterações em sua função prototípica de hipotática adverbial final que a levaram a assumir outros sentidos mais especializados e menos concretos.

Tendo em vista que as hipotáticas detêm um estatuto sintático mais frouxo migram, em seu processo de abstratização, para um laço mais gramatical de encaixamento, o que representa um mais forte entrelaçamento. Isso pressupõe um processo de gramaticalização em andamento.

Como apresentei no capítulo 2, as mudanças na língua já eram observadas desde o latim, e na mudança para o português, as estruturas para + infinitivo acabam sofrendo alterações tanto sintáticas quanto semânticas. Essas alterações são tão evidentes que, em muitos casos, é quase impossível compreender e classificá-las quanto aos seus verdadeiros estatutos semânticos ou sintáticos. Autores de gramáticas históricas já notavam a presença de estruturas que não se encaixavam em concepções normativistas, assim, ainda no capítulo 2, apresentei uma discussão sobre a atenção dos gramáticos, e dos autores de livros didáticos para tais mudanças desta estrutura.

O que pude observar é que apenas os lingüistas e autores de gramáticas de usos fazem menção aos diferentes usos que as estruturas para + infinitivo podem apresentar. Os livros didáticos, além de não abordarem tais mudanças, ainda apresentam exemplos ambíguos e usos que não os escolhidos pelos alunos, o que os leva a cometer "erros" do ponto de vista do ensino gramatical.

Os autores dos livros didáticos apresentam exemplos de conectores como sendo os preferenciais e mais utilizados, o que me levou a verificar a veracidade de tais 
afirmações. Nos dados, contudo, analisados no capítulo V, por meio da aplicação de um teste sobre o uso dos conectores em orações finais, reuni resultados divergentes em relação ao que as gramáticas normativas propõem. Buscando uma causa para isso, verifiquei que os alunos fazem uso de orações para + infinitivo como forma de evidenciar orações de finalidade sem opção de outras formas de marcação na maioria dos casos.

No capítulo III, os resultados da análise de amostras de língua falada em contraponto com a língua escrita mostraram muito semelhantes, o que me fez supor que a mudança na língua escrita tem sido capitaneada pela interferência da língua falada. Em situação de fala, contudo, as mulheres cultas quase não utilizam as estruturas para + infinitivo, e os poucos dados são dos usos prototípicos, o que ratifica as colocações sociolingüísticas quanto à adesão à normatividade pelo sexo feminino.

As estruturas conformadas em para + material interveniente + verbo infinitivo, tanto nos dados de língua falada quanto nos dados de língua escrita, revelam não ser um fator decisivo, mas um grande fator para o distanciamento dessas estruturas do seu valor prototípico.

Mais adiante, mostrei que a polaridade negativa está associada às mudanças operadas. Quando as estruturas para + infinitivo se juntam às estruturas de polaridade negativa desencadeia-se o distanciamento e desbotamento semântico dessas estruturas. Isso ficou evidenciado e ratificado pelas respostas colhidas durante a aplicação de um teste para os professores.

Grande parte dos professores não percebe as mudanças pelas quais estão passando as orações para + infinitivo e, motivados pelas gramáticas normativas, apenas associam essas orações ao conjunto de adverbiais finais, não percebendo as alterações sintáticas e semânticas que estas apresentam. No entanto, quando se deparam com estruturas associadas à polaridade negativa, não conseguem perceber nenhum valor final, nem mesmo por associações de conectores. Esse seria um indício de que o fator polaridade afeta o estatuto sintático e semântico das orações para + infinitivo.

O verbo modalizador poder interpolando para + verbo infinitivo aparece somente nos dados de língua falada, sendo, dessa forma, evitado na língua escrita. 
Assim, também é um dos fatores que propicia mudanças semânticas das estruturas infinitivas, uma vez que, associado aos valores de modalidades, são geralmente relacionados à possibilidade ou necessidade, o que favorece o desbotamento semântico das estruturas infinitivas, com a associação das mesmas aos valores de condição.

Percebe-se, também, pela quantificação realizada com o auxílio dos programas varbrul, que as orações com sujeitos não-correferenciais são as que apresentam maior produtividade de usos inovadores, o que ratifica o que Lehmann (1988) e outros pesquisadores já disseram a respeito.

Dentre todas as mudanças e seus possíveis causadores, percebi que algumas estruturas revelam um caráter extremamente ambíguo e divergente. Esses tipos de estruturas causam uma dificuldade muito grande para a compreensão das mesmas. $\mathrm{O}$ que causa preocupação é que até mesmo os livros didáticos apresentam tais estruturas, no entanto não mostram a diversidade de funções tanto semânticas quanto sintáticas que as mesmas podem apresentar.

Durante o processo de análise, igualmente pude perceber que algumas estruturas para+infinitivo apresentam-se em duplicidade no mesmo contexto, o que dificulta a localização da oração núcleo. Esse caso esdrúxulo de construção denuncia que nem sempre os processo de combinação de orações podem ser abarcados pelos rótulos da Nomenclatura Gramatical Brasileira. Isso, aliás, já foi observado por muitos trabalhos de funcionalistas na segunda metade do século $\mathrm{XX}$, alguns dos quais apresentei em revisão nos capítulos iniciais desta dissertação.

Esses casos "esdrúxulos" revelam-se estruturas extremamente entrelaçadas com toda a estrutura que a envolve. De qualquer forma, o que ocorre de fato é um processo de intensa amalgamação de estruturas que não podem ser compreendidas se lidas isoladamente. Essas estruturas amalgamadas e entrelaçadas tornam-se polissêmicas, uma vez que é impossível decidir ou reconhecer sua oração-núcleo.

Outro problema que gera um processo de gramaticalização das orações para + infinitivo são casos em que há os verbos ter e dar na oração núcleo. O encaminhamento seguido aqui para a análise segue o que funcionalistas já fizeram em momentos anteriores, qual seja, são resultantes de apagamentos sintagmáticos. Decorre desse 
apagamento a cristalização de uma nova estrutura junto do conector para, o que acaba trazendo um desbotamento semântico para as estruturas para + infinitivo.

Esta pesquisa permitiu evidenciar também que são diversos os fatores que influenciam nas mudanças pelas quais a estrutura para+infinitivo está passando. $\mathrm{O}$ verbo da oração matriz pode levar as orações para + infinitivo a migrarem do seu estatuto de adverbiais finais para outros que não os estipulados pelas gramáticas normativas.

Concluída a análise, uma grande preocupação emerge e diz respeito ao fato de nem mesmo os educadores estarem atentos às transformações pelas quais a língua passa. O não reconhecimento de um movimento lingüístico natural pode trazer prejuízos ao aluno (que tem seus usos e interpretações taxados de incorretos) e ao professor (que não se permite olhar criticamente para o modelo ensinado na escola). Torna-se imperioso, portanto, o estudo da língua em sua dinamicidade, mesclando-se modalidades distintas (fala e escrita) a situações de usos também variados (funções sociolingüísticas). 


\section{REFERÊNCIAS BIBLIOGRÁFICAS}

AZEVEDO, João Luiz Ferreira de. Conseqüências discursivas e semânticas da mobilidade das orações finais no português escrito. Rio de Janeiro: Revista Universidade Rural, Ser. Ciências Humanas, 2002.

BECHARA, Evanildo. Moderna Gramática Portuguesa. Rio de Janeiro: Lucerna, 1999.

BRAGA, Maria Luiza. As orações encaixadas no dialeto carioca. Conferência apresentada em concurso para Professor Titular junto ao Departamento de Lingüística e Filologia da Faculdade de Letras da Universidade Federal do Rio de Janeiro, 1999 (inédito).

BYBEE, Joan; PERKINS, Revere \& PAGLIUCA, William. The evolution of grammar: tense, aspect and modality in the languages of the world. Chicago/London: The University of Chicago Press, 1994.

CAMPBELL, Lyle \& JANDA, Richard. Introduction: conceptions of grammaticalization and their problems. New Zeland/Columbus:Elsevier Science Ltda, 2000 .

CASTILHO, Ataliba Teixeira de; PRETI, Dino Fioravanti. A linguagem falada culta na cidade de São Paulo, Volume II - Diálogos entre dois informantes, São Paulo: Fapesp,T.A.Queiroz,Editor, LTDA,1987.

CEGALlA, Domingos Paschoal. Novíssima Gramática da Língua Portuguesa. São Paulo: Nacional, 2005.

CEREJA, William Roberto e MAGALHÃES, Thereza Cochar. Português: Linguagens. São Paulo: Ed. Atual, 2004.

CIPRO NETO, Pasquale e INFANTE, Ulisses. Gramática da Língua Portuguesa. São Paulo: Scipione, 1997.

COUTINHO, Ismael de Lima. Pontos de Gramática Histórica. Rio de Janeiro: Livraria Acadêmica, 1974.

CUNHA, Celso \& CINTRA, Lindley. Nova Gramática do português contemporâneo. Rio de Janeiro: Nova Fronteira, 1982.

DEFENDI, Cristina Lopomo. A reduplicação no português culto falado em São Paulo: possível gramaticalização?. Dissertação de Mestrado. São Paulo: Universidade de São Paulo, 2008.

DIAS, Augusto Epiphanio da Silva. Sintaxe Histórica Portuguesa. São Paulo: Livraria Clássica Editora, 1970. 
DIAS, Nilza Barrozo. As cláusulas de finalidade. São Paulo: Universidade Estadual de Campinas, 2001.

- As funções discursivas das cláusulas de finalidade. Rio de Janeiro: Revista Veredas, 2002.

Cláusulas de finalidade: relações gramaticais convergentes $e$ divergentes na fala e na escrita. Rio de Janeiro: Revista Estudos Lingüísticos, 2005.

FERRARI, Lílian Vieira. A gramaticalização de formas não-finitas como evidência da motivação conceptual do léxic., Rio de Janeiro: Revista Veredas, 1998.

GORSKI, Edair Maria. Combinação de Orações: Gramaticalização de Fenômenos Coocorrentes. Porto Alegre: Revista Letras de Hoje, 2000.

Reflexos da gramaticalização de itens lexicais sobre a gramaticalização de sentenças complexas. Porto Alegre: Revista do Gelne, 2001.

; MITTMANN, Maryualê Malvessi e NEVES, Priscilla. $O$ Estatuto Sintático Camaleônico de certas construções infinitivas : Uma abordagem Pancrônica. Florianópolis: Working, papers em lingüística, 2003.

e NEVES, Priscilla. $O$ estatuto sintático do infinitivo em orações reduzidas: É legal (de) estudar esse assunto? João Pessoa: Anais do II ECLAE, Revista Gelne, 2004.

O estatuto sintático Camaleônico de certas construções infinitivas: Uma abordagem Pancrônica. Santa Catarina: 2003.

HEINE, Bernd; CLAUDI, Ulrike \& HÜNNEMEYER, Friedderike. Grammaticalization. A conceptual Framework. Chicago e London: The University of Chicago Press, 1993

HOPPER,Paul J.\& TRAUGOTT,Elizabeth Closs. Gramaticalization. Cambrige: Cambrige University Press, 1994.

LIMA, Ana, Funções textual-discursivas das 'orações adverbiais' sem matriz. Pernambuco: Revista Veredas, 2004.

LIMA-HERNANDES, Maria Célia. Estágios de gramaticalização da noção de tempoprocessos de combinação de orações. São Paulo: Revista Veredas, 2004.

Gramaticalização de Combinação de Cláusulas:

Orações de tempo no português do Brasil. São Paulo: Universidade de São Paulo, 1998.

LUFT, Celso Pedro. Gramática Resumida. Porto Alegre: Globo, 1987.

MAIA, João Domingues. Português. São Paulo: Ed. Ática, 2003. 
MATTOS e SILVA, Rosa Virgínia. Estruturas trecentistas: elementos para uma gramática do português arcaico. Lisboa: Imprensa Nacional, 1989.

MAURER, Theodoro Henrique Jr. O problema do latim vulgar. Rio de Janeiro: Livraria Acadêmica, 1962.

Acadêmica, 1959. Gramática do latim vulgar. Rio de Janeiro: Livraria

MENEZES, Vanda Cardozo de. Construções para + infinitivo: um motivo para repensar o ensino da gramática. Rio de Janeiro: Revista Linguagem \& Ensino, Pelotas, 2004.

iniciadas por para. Rio de Janeiro: Revista Estudos Lingüísticos, 2004.

de Janeiro: Revista Veredas, 2004.

Contextos de encaixamento: verbo ter na matriz. Rio

NEVES, Maria Helena de Moura. Gramática de usos do português. São Paulo: Ed. Unesp, 2002.

Texto e gramática. São Paulo: Ed. Contexto, 2006.

SAID ALI, Manuel. Gramática Histórica da Língua Portuguesa. Rio de Janeiro: Melhoramentos, 1971.

SALLES, Heloisa Maria M. Lima. Infinitives clauses as substitutes for subjunctive clauses in Brazilian Portuguese. University of Wales, 2003.

SARTIN, Elisângela Baptista de Godoy e LIMA-HERNANDES, Maria Célia. Eu quero que você leia meu trabalho.Gramaticalização de estruturas volitivas no português brasileiro. São Paulo: UNICSUL, 2006.

SILVA, Iandra Maria da Silva. Indicativo e Subjuntivo em Espanhol: Norma e Uso na imprensa escrita, Florianópolis, 2005.

TERRA, Ernani e NICOLA, José de. Português de olho no mundo do trabalho. São Paulo: Ed. Scipione, 2004. 